\title{
Māori, Biculturalism and the Assemblies of God in New Zealand, 1970 - 2008
}

\author{
By \\ Philip D. Carew \\ A Thesis \\ Submitted to the Victoria University of Wellington \\ in fulfilment of the \\ requirements for the degree of \\ Masters of Arts \\ in Religious Studies
}

Victoria University of Wellington

Te Whare Wānanga O Te Ūpoko O Te Ika a Māui 2009 


\section{ABSTRACT}

This thesis examines the extent to which the New Zealand Assemblies of God, one of the largest and oldest Pentecostal denominations in the country, has fostered participation by Māori, and its success in doing so between 1970 and 2008. From the advent of the Mana Māori renaissance in the 1970s the idea of biculturalism became an important vehicle for Māori aspirations. As part of its broader agenda, the thesis also considers the church's response to this bicultural emphasis. The Assemblies' particular response is analysed in the light of experiences in the mainline denominations and the Apostolic and Destiny churches which either experienced considerable success in attracting Māori participation, or explicitly accommodated the call for a bicultural response using recognised bicultural models.

The research is based on the published literature of the Assemblies of God and an extensive range of interviews. These provided detail on the motivations and underlying beliefs that have generated particular responses. The published literature of the other denominations has also been addressed for comparative purposes, along with a range of relevant secondary literature.

The Assemblies of God's flexible structure, clarity of teaching, fostering of indigenous leadership and emphasis on local church autonomy, has enabled it to grow rapidly throughout the world. Despite this, and despite the church's emphasis on crosscultural mission, this thesis demonstrates that Māori have not joined the Assemblies of God to the same extent that they have other Pentecostal denominations in New Zealand. It argues that the church has done little to foster Māori participation in the movement, and identifies eight key historical, ideological, and organisational factors that have hindered its ability to do so. In particular, it highlights the significance of the denomination's emphasis on local church autonomy, the absence of any deliberate "mission" to Māori, and the church's multicultural emphasis and historical suspicion of "social justice". 


\section{ACKNOWLEDGEMENTS}

I wish to thank my two supervisors, Dr Geoff Troughton and Dr Chris Marshall of Victoria University of Wellington. Dr Troughton, my primary supervisor in the Religious Studies department, "midwife at a problematic pregnancy," who accompanied me on this research journey, introduced me to a wide range of relevant literature, encouraged objectivity and provided guidance on the process of academic writing. Dr Chris Marshall provided reflective comment and enthusiasm for the project throughout.

Many others deserve my thanks and sincere gratitude. Pastor Ken Harrison, General Superintendent of the New Zealand Assemblies of God, encouraged me in this project and offered frank and objective comment on the movement. Ian Clark, Pastor, former General Secretary of the Assemblies of God, Bible College Principal and church historian, provided an open reflection on the church and a list of valuable contacts. My fellow members at Avalon Assemblies of God church who shared their experiences in the movement, personal spiritual journeys and encounters with Māori. Staff, parents and supporters of Paparakau Tuarua Kohanga Reo enabled me to share in the community life associated with the preschool and offered valuable insights on Māori perspectives and their past association with an Assemblies of God church. A number of pastors contributed their experiences and reflections. Senior figures in other organisations offered valuable comment on their particular organisation's experiences of biculturalism. Darrin Rogers of the Flower Pentecostal Heritage Centre in the United States pointed me in the direction of salient material on the Assembly of God USA's cross cultural experience.

To my wife Lyn, companion and supporter with an eye for detail: your patience and support have been inestimable. Thank you. 


\section{TABLE OF CONTENTS}

Abstract $\quad$ i

$\begin{array}{ll}\text { Acknowledgements } & \text { ii }\end{array}$

Table of Contents

List of Tables $\quad$ iv

$\begin{array}{ll}\text { Introduction } & 1\end{array}$

Chapter One: Pentecostalism, Ethnicity and the Assemblies of God 10

$\begin{array}{ll}\text { Global Pentecostalism } & 10\end{array}$

New Zealand Pentecostalism $\quad 18$

The Assemblies of God in New Zealand 20

Chapter Two: Biculturalism and the Mainline Churches 39

$\begin{array}{ll}\text { Biculturalism } & 39\end{array}$

The Mainline Churches and Biculturalism 46

Missionaries, the Crown, and the "Very Sacred Deed" 54

Chapter Three: Biculturalism and the New Zealand Assemblies of God 60

Māori and the Assemblies of God to $1970 \quad 60$

Māori and the Assemblies of God from 1970 to 2008

Pākehā Pastoral Reflections on Ministry Among Māori 79

Chapter Four: Biculturalism, the Apostolic and Destiny Churches 90

The Apostolic Church in New Zealand to $1994 \quad 90$

The Rise of the Destiny Movement 99

The Apostolic Church from $1994 \quad 104$

Chapter Five: The Assemblies of God and Māori in Comparative Perspective 112

Biculturalism Revisited 112

Factors Shaping the Assemblies of God's Approach to Māori 117

$\begin{array}{lr}\text { Conclusion } & 132\end{array}$

$\begin{array}{ll}\text { Appendix A: Interviews Referred to in the Thesis } & 139\end{array}$

$\begin{array}{ll}\text { Appendix B: A Glossary of Māori Words } & 142\end{array}$

$\begin{array}{ll}\text { Bibliography } & 146\end{array}$ 


\section{LIST OF TABLES}

Table 1: Age of Attendees: Assemblies of God - Wellington Region 34

Table 2: Ethnic Composition of the Assemblies of God, 1992 and 2009, With a Comparison to the 2006 National Census Figures

Table 3: Ethnic Composition of the Apostolic Church, 1992-2009

Table 4: 1966 and 2006 Comparative Māori Adherents Statistics 


\section{INTRODUCTION}

Māori, the indigenous people of New Zealand, have been present in the country for approximately the last 800 years. Their traditional way of life was significantly affected by ever increasing European immigration from the late 1700s. The arrival of Christian missionaries from 1814 marked a significant new era, even though Māori acceptance of Christianity was initially minimal. By the mid-1830s, this situation had begun to change as a period of large-scale conversion to Christianity ensued. The reasons for this change have been hotly contested, as scholars have variously posited the carnage of the intertribal musket wars, trade, changing missionary methods, and the advent of literacy and print as crucial contributing factors. ${ }^{1}$ By some reputedly conservative estimates, as many as $60 \%$ of Māori had converted by the mid-1840s. Their commitment was seriously challenged by events that followed. ${ }^{2}$

Negative perceptions of previous colonisations and the influence of the Evangelical movement in Britain significantly affected the British approach to colonisation in New Zealand. The Crown endeavoured to legitimise its presence in the country by the signing of the Treaty of Waitangi with the chiefs of the disparate Māori tribes on 6 February 1840, and in following months. Christian missionaries played a significant part in endorsing and promoting the value of the Treaty to Māori, and encouraging them to sign. Yet, the spirit and intent of the Treaty were not maintained and Māori were subject to the onslaught of war, swamping immigration, European

\footnotetext{
${ }^{1}$ For a recent assessment of these, and another analysis, see Tony Ballantyne, "Christianity, Colonialism and Cross-cultural Communication," in Christianity, Modernity and Culture, ed. John Stenhouse (Hindmarsh: ATF Press, 2005), 23-57.

${ }^{2}$ James Belich, Making Peoples: A History of the New Zealanders from Polynesian Settlement to the End of the Nineteenth Century (Auckland: Penguin Books, 1996), 216-219.
} 
diseases, dispossession, and the undermining of Māori social structures, language and culture. By the end of the nineteenth century there was a widespread expectation that Māori were destined for extinction. This did not occur and projections are that by 2021, $17 \%$ of New Zealand's population will be able to legitimately claim Māori ancestry. ${ }^{3}$ Nevertheless, the legacies of nineteenth-century missionary activity, and Christianisation of Māori, were to profoundly influence churches' perceptions of their responsibilities and obligations in the markedly altered conditions that emerged from the 1970s.

\section{Thesis Objectives and Rationale}

This thesis has the dual objective of seeking to determine the extent to which the New Zealand Assemblies of God has fostered participation by Māori, and the church's attitude toward biculturalism during the period 1970 to 2008 . The timeframe has been shaped by the convergence of two relevant and notable trends. The first of these was what Michael King termed the rise of "Mana Māori", ${ }^{4}$ while the second was the rapid growth of Pentecostalism in New Zealand.

Biculturalism came to public attention in the 1970s out of the ferment of the Mana Māori resurgence, a renewal of interest in things Māori encouraged by the challenges of their rapid urbanisation after World War II. Protest marches, land occupations, articulately outspoken Māori, government reports, legislation and renewed emphasis on the use of te reo all drew attention to historical injustices toward Māori. Calls for redress of these gathered strength, as did those for recognition of the status of

\footnotetext{
${ }^{3}$ Maori Health, "Demographic, Population Projections," http://www.maorihealth.govt.nz/moh.nsf/indexma/population-projections (accessed 19 August 2009).

${ }^{4}$ Michael King, The Penguin History of New Zealand Illustrated (North Shore: Penguin, 2007), 400.
} 
Tangata Whenua, and tino rangatiratanga, or their right to live in a manner acceptable to them. Mainline denominations, which had relatively long associations with Māori heeded these calls and in most cases implemented changes in their structures to recognise their perceived responsibilities. Government departments began to change their protocols to reflect bicultural ideals of partnership, and to support initiatives that were designed to revitalise the culture.

Pentecostalism, a renewal movement that arose from a series of revivals around the beginning of the twentieth century in a number of countries, ${ }^{5}$ traditionally appealed to the poor, marginalised, minority and dispossessed communities. During the latter decades of the century, it moved from being a small fringe movement to one that occupied a more influential place within New Zealand Christianity. The Charismatic movement introduced Pentecostal-like experience into the mainline denominations. Consequently, Pentecostalism became more socially acceptable. An increasingly educated middle class constituency and a weakening sectarian emphasis enabled it to connect with a broader constituency.

Growth in Pentecostalism worldwide has been one of the remarkable aspects of twentieth century Christian history. With an estimated 60 million adherents, the Assemblies of God is the largest single Pentecostal denomination in the world. If the Charismatic churches are included in a broad definition of Pentecostalism, the Assemblies of God are second only in size to the Catholic charismatic movement. While slow to start in New Zealand, Pentecostalism grew significantly during the 1970s. So, too, did the Assemblies of God. It is now the largest Pentecostal

\footnotetext{
${ }^{5}$ Revivals occurred in India, Korea, Japan, England, Wales, Scotland, Australia, South America and the United States. Allan Anderson, An Introduction to Pentecostalism (Cambridge: Cambridge University Press, 2004), 24, 36-37, 91-92, 140.
} 
denomination in the country. The 2006 census indicates that its 15,300 adherents are nearly twice as many as the next largest Pentecostal denomination, and about one fifth of total Pentecostal numbers. ${ }^{6}$ The church's own statistics put adherents at around $25,000 .{ }^{7}$ Numerical growth has been accompanied by a changing public profile, and the Assemblies of God has arguably become mainstreamed within the New Zealand Christian denominations. The present General Superintendent, Ken Harrison, facilitates the group of interdenominational representatives who meet with the Prime Minister on a twice-yearly basis to discuss matters of Government policy. ${ }^{8}$

Despite this increasing size and profile, the New Zealand Assemblies of God has not been the subject of much academic research. While Pentecostalism is the focus of an increasing amount of attention world wide, New Zealand Pentecostalism is an understudied tradition. Few histories have been written. The most thorough and rigorous studies include a now dated survey of the movement as a whole, ${ }^{9}$ a history of the New Life Movement, ${ }^{10}$ and a recent history of the Assemblies of God. ${ }^{11}$ No particular scholarly attention has been given to the place of Māori in the Pentecostal experience.

Exploring the interface of Pentecostalism and cultural relations in New Zealand is particularly significant for a number of reasons. At one level, the focus on

\footnotetext{
6 "Religious Affiliation (Total)," 2006CensusQSCI, Table 31, Christine Dean (Department of Statistics) email to Philip Carew, 30 January 2009.

${ }^{7}$ Interview with Neil Hetrick, 23 January 2009.

${ }^{8}$ Jonathan Young, "National Church Leaders Forum Appoints Ps Harrison as their Chairman," Empowered: Magazine of the Spirit-Empowered Life, Summer 2008: 2.

${ }^{9}$ James E. Worsfold, A History of the Charismatic Movements in New Zealand (Bradford: Julian Literature Trust, 1974).

${ }^{10}$ Brett Knowles, New Life: A Brief History of the New Life Churches in New Zealand 1942-1979 (Dunedin: Third Millennium, 1999).

${ }^{11}$ Ian G. Clark, Pentecost at the Ends of the Earth: The History of the Assemblies of God in New Zealand, 1927-2003 (Blenheim: Christian Road Ministries, 2007).
} 
Pentecostalism is justifiable on account of its increasing prominence in New Zealand's religious landscape. More specifically, while we know something of the response of mainstream churches to biculturalism, Pentecostal responses remain largely unexplored. Yet, they are potentially significant. Pentecostal churches have been widely recognized for their cultural diversity, which partly reflects their historical appeal to marginalized social groupings in many parts of the world. ${ }^{12}$ In New Zealand, Māori have formed a significant presence within most Pentecostal streams, despite attitudes within the movement that were often deeply suspicious of Māori culture.

There is a perception that Māori participation in the Assemblies of God is lower than that experienced by other Pentecostal churches, a perception supported both by a 1992 survey carried out by the church and ongoing observation by the leadership of the movement. This perception invites investigation, and provides part of the context for exploring responses to biculturalism within the denomination. Church leaders clearly considered that the movement's limited appeal to Māori was a problem. From 1988, the Assemblies of God sponsored a number of events to facilitate awareness of Māori and Pacific cultures and to strategize on how to more effectively connect with the Māori community. ${ }^{13}$ In 2007, the denomination's General Council reiterated concern about its failure to achieve Māori participation and appointed Pastor Peter Hira, a senior pastor and former Executive member, to inaugurate an enquiry into the issue. Given this ongoing concern, the failure of the church to engage with Māori seems all the more striking.

\footnotetext{
${ }^{12}$ Marion Maddox, God Under Howard: The Rise of the Religious Right in Australian Politics (Crows Nest: Allen \& Unwin, 2005), 225.

${ }^{13}$ Clark, Pentecost at the Ends of the Earth, 204.
} 


\section{Methodology}

The research will test the perception that the Assemblies of God failed to engage with Māori by examining levels of Māori participation, and attitudes to culture within the movement. In particular, the thesis assesses the Assemblies of God's response to issues of biculturalism as they emerged from the 1970s. This assessment will be carried out in the light of developments within six other denominations. The four "mainline" churches all responded deliberately to the emergence of biculturalism, while the Apostolic Church and one of its progeny, the Destiny Church, are Pentecostal churches that have been successful in achieving high levels of Māori participation. Comparing the responses and experiences of these denominations helps provide a broader context, and a framework for evaluating the Assemblies of God's initiatives.

A range of methodologies have been utilised, making use of oral and written sources. The Assemblies have limited archival material and these were not made available for this research. Published denominational literature including The New Zealand Evangel (1969-2004), Empowered (2005-present), and the Apostolic News (1980-2008) were used extensively as a primary source base, along with newspaper reports of relevant events.

Forty-seven interviews supplement the documentary information. These were conducted with a range of individuals, including leaders within the Assemblies of God, leaders of other denominations and movements, members of an Assemblies of God congregation, supporters and parents associated with a Kohanga Reo that formerly operated on Assemblies of God church premises. ${ }^{14}$ Interviews provided important information on the underlying issues and motivations behind events, and the desires,

\footnotetext{
${ }^{14}$ See Appendix A for a full description of interviewees.
} 
aspirations and motivations of significant participants and observers of the denomination. Interviewees were chosen because of the positions they held within organisations or because they were regarded as representative of the organisations they participated in.

Some quantitative data has been gained through a survey of the Assemblies of God churches in the Wellington region. This was undertaken in order to gain a clearer indication of the character and composition of the movement. The survey provided information on levels of Māori participation in the denomination, as well as its overall ethnic composition together with other indications of the age profile, length of tenure and regularity of attendance at collective worship. This data was compared with information from the Department of Statistics, and a previous Assemblies of God national survey carried out in 1992.

\section{Outline}

This thesis is divided into five main chapters. The first two chapters locate the Assemblies of God in New Zealand within the story of global Pentecostalism, and provide background to the rise of biculturalism in New Zealand. Chapter One briefly traces the development of Pentecostalism, and the Assemblies of God with a view to identifying key denominational influences and characteristics. Chapter Two explores the growing importance of biculturalism within New Zealand society, in order to locate Pentecostal attitudes within a spectrum of responses from churches. In particular, the chapter considers responses of the four "mainline" churches. 
The main sections of the thesis address ways the Assemblies of God conceptualised issues concerning bicultural relations, based on the use of primary denominational sources and interviews with selected figures within the movement. Chapter Three details the extent of the Assemblies of God's engagement with Māori, and evidence of attempts to grapple with issues of biculturalism during the period since 1970. It draws attention to opportunities that the Assemblies of God had to connect with Māori and ways the church responded. For comparative purposes, Chapter Four analyses the experiences of the Apostolic and Destiny churches, and their engagement with Māori and issues of biculturalism. In the light of these varied experiences, a final analytical chapter, Chapter Five, identifies eight key factors that shaped the Assemblies of God's response to issues of biculturalism that have affected the denomination's willingness to engage with Māori and success in doing so. A brief conclusion follows.

The thesis argues that the perception of limited Māori participation in the Assemblies of God is correct, and that the denomination has largely been unsympathetic to bicultural ideas. The various theological, sociological and ideological factors that led to this will be addressed in the following chapters. Overall, this situation highlights some interesting paradoxes. In global terms, Pentecostalism expanded rapidly in the twentieth century due to the theological certainties it offered, its imminent eschatology, and a vital, flexible structure that quickly developed indigenous leadership. It is a movement that strongly prioritises both personal spiritual experience, and evangelisation. Despite its adaptability, it has tended to adopt a conservative social and theological agenda. It has often avoided addressing issues of social justice, perceiving these to be a distraction from the task of world evangelisation and the 
conviction that the solution to all humankind's problems are found in the lordship of Jesus Christ. ${ }^{15}$ These dimensions help explain attitudes to biculturalism. But the limited presence of Māori in the Assemblies of God remains unusual given the missionary emphasis within Pentecostalism, and the experience of other Pentecostal denominations within New Zealand. To address the particular experience of the Assemblies of God in these areas is therefore to consider a significant puzzle in the story of Pentecostalism in New Zealand.

\footnotetext{
${ }^{15}$ Assemblies of God USA, "The Church at Large: The Body of Christ," http://ag.org/top/Beliefs/sptlissues_church_at_large.cfm (accessed 27 August 2009).
} 


\section{CHAPTER ONE}

\section{Pentecostalism, Ethnicity and the Assemblies of God}

Pentecostalism emerged in the early twentieth century, and quickly became established as a vibrant and influential tradition. Within one hundred years, through its association with the Charismatic movement of the mainline churches and the more liberal Third Wave, it became widely acknowledged as one of four main streams within global Christianity, alongside Catholicism, Protestantism and the Orthodox traditions. The significance of the movement in the twentieth century is underscored by its rapid numerical growth, global expansion and ethnic diversification. Issues of race and ethnicity created difficulties from its earliest days.

The Assemblies of God arose from within the Pentecostal tradition, emerging in New Zealand during the 1920s. This chapter considers key characteristics of the denomination, with particular reference to factors shaping its ethnic composition. In New Zealand, as elsewhere, the Assemblies of God has become increasingly respectable and ethnically diverse. Nevertheless, while the participation of Māori has been a feature of the New Zealand Pentecostal movement in general, their profile in the Assemblies of God is lower than in most other denominations. 


\section{Global Pentecostalism}

Pentecostalism belongs to the stream of Christianity that places great importance on a personal post-conversion experience of the Holy Spirit, described as the Baptism of the Holy Spirit. ${ }^{16}$ Other notable beliefs include prayer for the sick, expressiveness in worship and a belief in spirit possession. ${ }^{17}$ Pentecostalism is paralleled by the Charismatic movement, which arose in the mainline churches from the late 1960s, and also by the "Third Wave" or "Signs and Wonders" movement in independent churches in following decades.

Classical Pentecostals hold firmly to Subsequence, the belief that the Baptism in the Spirit is distinct and separate from salvation. The Spirit, totally present at conversion is believed to totally claim that person through Spirit baptism. ${ }^{18}$ Some Pentecostals insist that the experience of Sanctification, or complete dedication of the individual to God, precedes the Baptism. ${ }^{19}$ Classical Pentecostals also hold to the view that the Initial Evidence of the Baptism of the Spirit is Speaking in Tongues, a supernaturally given human (xenolalia) or unknown (glossolalia) language. ${ }^{20}$ While they maintain a conservative theological position, their emphasis on Speaking in Tongues, healing and the tendency to a subjective biblical hermeneutic put them at odds with Protestant Fundamentalists. ${ }^{21}$ Pentecostal hermeneutics are focused almost

\footnotetext{
${ }^{16}$ Luke Wesley Worsfold, "Subsequence, Prophecy and Church Order in the Apostolic Church, New Zealand," PhD Thesis in Religious Studies, Victoria University of Wellington, 2004, 129.

${ }^{17}$ E. A. Wilson, "Brazilian Pentecostalism," in International Dictionary of Pentecostal and Charismatic Movements (IDPCM), eds. Stanley M. Burgess and Eduard M. Van Der Maas (Grand Rapids: Zondervan, 2002), 40.

${ }^{18}$ J. R. Williams, "Baptism in the Holy Spirit," in IDPCM, 355-356.

${ }^{19}$ E. L. Blumhofer and A. R. Armstrong, "Assemblies of God," in IDPCM, 339.

${ }^{20}$ Robert Mapes Anderson, Vision of the Disinherited: The Making of American Pentecostalism (New York: Oxford University Press, 1979), 164.

${ }^{21}$ Anderson, Vision of the Disinherited, 147; H. V. Synan, "Fundamentalism," in IDPCM, 655-658;

Anderson, An Introduction to Pentecostalism, 226, 258.
} 
exclusively on the theology of the Gospel of Luke and Acts, in contrast to the Protestant / Fundamentalist Pauline emphasis. ${ }^{22}$

Charismatic and Third Wave movements do not place such a strict emphasis on Initial Evidence, believing the Baptism to be expressed in a number of ways. Nor do they necessarily regard Baptism as something distinct from personal salvation (Subsequence), but rather as a manifestation of something present in potential at salvation, being manifested at the Baptism. ${ }^{23}$ They embrace a wider range of theological positions and have been more ready to accept Roman Catholicism and organisations like the National Council of Churches. Peter Wagner, who first used the name "Third Wave", defines it as a movement of those who believe that the Baptism of the Spirit occurs at conversion, and that there is the potential for multiple fillings of the Spirit after conversion. They also have a low key acceptance of tongues as a gift that God gives to some and not to others, believe in ministry under the power and anointing of the Holy Spirit and the avoidance of divisiveness for the sake of unity. Third Wave terminology aims to distinguish the vast numbers of independent and indigenous fellowships with these characteristics worldwide that cannot be defined as Pentecostal or Charismatic. ${ }^{24}$

Recent estimates of the total number of adherents within the Pentecostal / Charismatic / Third Wave movements have varied between about 345 million and 523 million in $2000 .^{25}$ The larger figure of 523 million includes a block of 394 million

\footnotetext{
${ }^{22}$ Donald W. Dayton, The Theological Roots of Pentecostalism (Grand Rapids: Zondervan, 1987), 23.

${ }^{23}$ Stanley M. Burgess, in IDPCM, xxi.

${ }^{24}$ C. P. Wager, "Third Wave," in IDPCM, 1141.

${ }^{25}$ Patrick Johnstone and Jason Mandryk, Operation World: $21^{\text {st }}$ Century Edition (Carlisle: Paternoster Press, 2001), 3, 21, 755, 757, 762; Anderson, Introduction to Pentecostalism, 1, with reference to David B. Barrett and Todd M. Johnson, "Annual Statistical Table on Global Mission: 2003," International Bulletin of Missionary Research 27, no. 1 (2003): 25.
} 
Independents, who are neither mainline Charismatic nor classical Pentecostal, though not necessarily Third Wave. Of these, 80 million are Han Chinese Christians, and a further 55 million belong to African independent churches. The largest group in all calculations are the Catholic Charismatics. The Assemblies of God is the next largest body, with approximately 60 million adherents worldwide. ${ }^{26}$

Pentecostalism is therefore truly global. While present in North America, United Kingdom and Scandinavia in large numbers, the majority of Pentecostals are now found in Africa, Asia and Latin America. ${ }^{27}$ In Latin America they are the largest non-Catholic grouping. The large independent Pentecostal churches of West Africa, Zaire and southern Africa, although sometimes excluded from the Pentecostal count, have derived much of their inspiration from Classical Pentecostalism. ${ }^{28}$

Pentecostalism is essentially a renewal movement. The modern historiography of the movement emphasises that global Pentecostalism sprang from a number of revivals that occurred more or less simultaneously throughout the world around the beginning of the twentieth century. These occurred independently, largely amongst lower socio-economic groups. The revivals, and the consequent emergence of Pentecostalism, have been variously attributed to a sense of spiritual or social discontent, an inability to accommodate the rapid change in science, technology and academic scholarship, ${ }^{29}$ a desire for something more to satisfy the personal "spiritual

\footnotetext{
${ }^{26}$ Assemblies of God USA, "Statistical Report 2006," http://ag.org/top/About/statistics/Statistical_Report_2006.pdf (accessed May 5, 2009); Assemblies of God USA, "Assemblies of God World Missions Report for 2007," http://worldmissions.ag.org/downloads/PDF/agwm_current_facts_08.pdf (accessed May 5, 2009).

${ }^{27}$ Anderson, Introduction to Pentecostalism, 12.

${ }^{28}$ James Dunn, "Pentecostalism and the Charismatic Movement," in The History of Christianity, ed. Tim Dowley (Oxford: Lion, 1990), 646-648.

${ }^{29}$ Anderson, Vision of the Disinherited, 222.
} 
vacuum" within, or a more specifically Christian search for power to accomplish the task of evangelism. ${ }^{30}$

The new historiography emphasises that Western missionaries often brought the message of Pentecost to Third World countries, but that indigenous people were responsible for its rapid expansion. Flexible forms of governance and local autonomy facilitated this. ${ }^{31}$ While the origins of Pentecostalism can therefore arguably be seen as a worldwide phenomenon, the story of the Assemblies of God follows the more conventional story of Pentecostal origins which are associated with events in Topeka, Kansas, and Azusa Street, Los Angeles. The denomination formed directly from that lineage.

\section{Classical Pentecostalism and the Origins of the Assemblies of God}

The social and spiritual discontent of the late nineteenth century propelled many Christians either toward modernism, with its higher criticism and questioning of traditional beliefs, or more earnestly into traditional beliefs. The Holiness Movement, with its emphasis on a sanctified and holy life, formed a significant group in the latter category. ${ }^{32}$ It formed the "soil" from which the well documented Azusa Street revival of 1906 arose.

William Seymour, an African American, was a protégé of the controversial Pentecostal pioneer Charles Parham. Parham had founded the Apostolic Faith Mission and along with his Bible School students in Topeka, Kansas experienced the Baptism of

\footnotetext{
${ }^{30}$ Anderson, Introduction to Pentecostalism, 64-67.

${ }^{31}$ Allan Anderson, "The Origins of Pentecostalism and its Global Spread in the Early Twentieth Century," http://www.ocms.ac.uk/docs/Allan\%20Anderson\%20lecture20041005.pdf (accessed August 14, 2009); interview with Ian Clark, 12 December 2008.

${ }^{32}$ Dunn, "Pentecostalism and the Charismatic Movement," 646-648.
} 
the Spirit with Speaking in Tongues. Seymour left this Bible School to work in Los Angeles, eventually establishing a mission at Azusa St in 1906 where he propounded Pentecostal doctrine. Thousands came to hear this new teaching, many experiencing the Baptism of the Spirit. Among them were the Mexican American Valdez family who later played an important role in the foundation of the Assemblies of God in New Zealand. ${ }^{33}$ The unstructured services at Seymour's mission regularly lasted for fourteen or more hours, continuing on a daily basis for over three years. They were marked by vitality and egalitarianism. Women and African Americans preached, African Americans and whites embraced and prayed for one another, men and women prayed for one another; some people rolled on the floors, others shouted out, or broke out spontaneously into song. There was a strong missionary emphasis, with some participants praying in the upstairs section of the mission for the outpouring of the Spirit on all humanity.

The mission was regularly mocked and ridiculed by the press. Parham visited, and was appalled at what he saw, regarding it as degrading and demeaning to the work of the Holy Spirit. He was barred from entering the mission after preaching against the racial mixing and what he regarded as the excesses of the movement. ${ }^{34}$ Nevertheless, similar missions spread rapidly throughout the city and missionaries were sent off all over the world, their destination being determined by what they supposed was the most likely origin of their Spirit-given language. These early mission experiences were generally not successful as those sent were often ill-equipped to deal with cross-cultural challenges.

\footnotetext{
${ }^{33}$ Clark, Pentecost at the Ends of the Earth, 22-26.

${ }^{34}$ Cecil M. Robeck, The Azusa Street Mission and Revival (Nashville: Nelson Reference and Electronic, 2006), 69-86.
} 
The Assemblies of God emerged out of the Azusa Street revival after the African American Holiness preacher, Bishop Charles H. Manson, visited, experienced the Baptism, and returned to his own denomination to preach the message of Pentecost. ${ }^{35}$ His denomination, the Church of God in Christ, split as a result. The Church of God in Christ had been able to negotiate heavily discounted rail passes for pastors. Apparently, a group of white pastors, operating in a loose collective, associated themselves with the denomination. Through an arrangement with the church they received the discounted rail passes with ministerial credentialing certificates, though they never appeared on official ministerial credential listings of the Church of God in Christ. It appears that Manson understood the reason for their association, but was happy to facilitate the spread of the Pentecostal message in this way.

In 1914, these white pastors left the movement to form their own denomination, the Assemblies of God. While some maintain that the reasons for the split were racially motivated, others believed this not to be the case, since there was no evidence of overt personal racism. ${ }^{36}$ What eventuated, however, was a largely white church that was reluctant, on a national basis, to credential African American pastors. ${ }^{37}$

The new denomination placed a strong emphasis on local church autonomy. The flexibility afforded by this type of structure proved ultimately beneficial to growth. Its roots, however, are likely to be found in the apprehension felt toward "institutional

\footnotetext{
${ }^{35}$ Robeck, The Azusa Street Mission and Revival, 219-222.

${ }^{36}$ On these varying interpretations, see Darrin J. Rogers, "The Assemblies of God and the Long Road to Racial Reconciliation," Assemblies of God [U.S.A.] Heritage 28 (2008): 51-53; Erik J. Hjalmeby, “A Rhetorical History of Race Relations in the Early Pentecostal Movement, 1906-1916," MA Thesis, Baylor University, Waco, 2007, 123; Donald Weeks, "History of the Church of God in Christ," (Oakland, CA: unpublished paper, 1989), 53, cited in Rogers, "The Assemblies of God," 54.

${ }^{37}$ Dunn, "Pentecostalism and the Charismatic Movement," 649; Edith L. Blumhofer, Restoring the Faith: The Assemblies of God, Pentecostalism, and American Culture, (Urbana: University of Illinois Press, 1993), 243-247; Rogers, “Assemblies of God,” 53, 58.
} 
religion" that characterised early Pentecostals. This tended to inhibit involvement in programmes that did not serve the interests of local churches. ${ }^{38}$ The denomination grew slowly at first and institutional priorities, like pastoral education and links with other Pentecostal and Evangelical organisations, emerged gradually. ${ }^{39}$ Rapid growth occurred at the end of the 1950s, and some of the largest churches in the United States, and most prominent televangelists, belonged to the movement. During the 1980s and 1990s the movement worked to find a balance between social acceptability and dynamic Pentecostal experience. ${ }^{40}$ A number of recent revivals such as the one that commenced in Brownsville, Pensacola, Florida USA in 1993, may indicate a revitalising of the Assemblies of God. ${ }^{41}$

Issues pertaining to "race" proved problematic for the movement, which was slow to respond to calls for equality and civil rights. The possibility of establishing a "Colored Branch" of the church garnered little interest ${ }^{42}$ and the involvement of the National Council of Churches made the denomination suspicious about calls for greater racial understanding during the 1960s. ${ }^{43}$ Nevertheless, in 1965 the denomination adopted a resolution affirming civil rights. Its statement declared that "the teachings of Christ are violated by discriminatory practices against racial minorities" and that Christian conversion "breaks down prejudice and causes justice to prevail". ${ }^{4}$

\footnotetext{
${ }^{38}$ Grant Wacker, Heaven Below: Early Pentecostals and American Culture (Cambridge, MA: Harvard University Press, 2001), 28, cited in Rogers, "Assemblies of God," 53; New Zealand Assemblies of God, "Objectives," http://www.agnz.org/about/beliefs/ (accessed 25 August 2009); Assemblies of God USA, “Our Form of Government," http://ag.org/top/About/structure.cfm (accessed 25 August 2009).

${ }^{39}$ Blumhofer and Armstrong, "Assemblies of God," 336; R. M. Riss, "Latter Rain Movement," in IDPCM, 830; Anderson, Vision of the Disinherited, 79.

${ }^{40}$ Blumhofer and Armstrong, "Assemblies of God," 337-338.

${ }^{41}$ Anderson, An Introduction to Pentecostalism, 285.

${ }^{42}$ Blumhofer, Restoring the Faith, 247.

${ }^{43}$ Blumhofer, Restoring the Faith, 249; Rogers, "Assemblies of God," 53.

${ }^{44}$ Blumhofer, Restoring the Faith, 249.
} 
Pressure from missionaries who advised the church that its record on race relations could jeopardise missionary endeavours in newly independent African states led to a stronger stand against discrimination. ${ }^{45}$ The church acknowledged its concerning record on race relations in 1989, deeming racism a sin. In 1993, public penitence was expressed in an event termed "the Memphis Miracle", where white pastors sought and received forgiveness from African American pastors. ${ }^{46}$ In 1997, the first non-Anglo person was appointed to the National Executive. The first African American was appointed in $2007 .{ }^{47}$ In light of the changes in society as a whole, these developments were a long time coming. The reluctance of the movement to engage with the African American community contrasts with its emphasis on cross-cultural engagement in the context of international mission. Many of these dynamics were also evident in the experiences of Māori and the Assemblies of God in New Zealand.

\section{New Zealand Pentecostalism}

International speakers brought the Pentecostal message to New Zealand in the early twentieth century. The most significant of these was the former Welsh plumber Smith Wigglesworth whose visit in 1922-23 resulted in the establishment of the Pentecostal Church of New Zealand. ${ }^{48}$ Wigglesworth ordained only one person and drew up no constitution or statement of beliefs while in the country. The movement struggled until another visiting speaker, A. C. Valdez, recommended that the Church adopt the

\footnotetext{
${ }^{45}$ Blumhofer, Restoring the Faith, 249.

${ }^{46}$ Rogers, "Assemblies of God," 58; Blumhofer, Restoring the Faith, 250.

${ }^{47}$ Rogers, "Assemblies of God," 50.

${ }^{48}$ Early visitors included Dr R. A. Torrey (1901), Robert (Gypsy) Smith (1907-8), Herbert Booth (191920). See Worsfold, A History of the Charismatic Movements, 64-79, 104-106; Clark, Pentecost at the Ends of the Earth, 16; Clark, "Tracing Our Roots," The Evangel, October 1987: 8; Anderson, An Introduction to Pentecostalism, 91-93.
} 
constitution and Statement of Fundamental Truths of the Assemblies of God USA. Not all congregations agreed, but those that did adopted the relevantly adapted constitution on 22 April 1927. ${ }^{49}$ Those that did not continued on as the Pentecostal Church of New Zealand. This was affected by further schism, and its remnant eventually joined with the Elim Church, which was of British origin.

The Apostolic Church began in New Zealand in the 1930s, and was perceived as a serious threat by the Assemblies of God. ${ }^{50}$ The Wilson Brothers' Commonwealth Covenant Churches commenced in Auckland and Wellington in the late 1930s bringing an intense interest in prophecy and the British Israelite doctrine. ${ }^{51}$ The Christian Revival Centre arrived in $1941,{ }^{52}$ while the Indigenous Churches, or New Life Movement as they came to be known, emerged during the 1940s and 1950s. The latter group had a reshaping influence on the other Pentecostal denominations by their indigenous leadership, vitality and ability to connect with a broader spectrum of New Zealanders. A significant feature of these churches was the tent crusades held, often in rural areas, attracting large numbers of Māori. ${ }^{53}$

Peter Morrow of the New Life church in Christchurch was one of a number of Pentecostal pastors who played a significant role in the introduction of mainline churches to the Pentecostal message, ushering in the Charismatic movement. Initially perceived as a threat and a theological quandary for the Pentecostal churches, the Charismatic movement soon facilitated "transfer growth" from mainline churches to

\footnotetext{
${ }^{49}$ Clark, "Tracing Our Roots," The Evangel, October 1987: 8; Clark, Pentecost at the Ends of the Earth, 31; interview with Ken Harrison, 6 November 2008.

${ }^{50}$ Clark, Pentecost at the Ends of the Earth, 49-50.

${ }^{51}$ B. Knowles, "New Zealand," in IDPCM, 187.

${ }^{52}$ M. Hutchinson, "Australia," in IDPCM, 27.

${ }^{53}$ Knowles, "New Zealand," 188.
} 
Pentecostal churches. Rather than being seen as a part of the "lunatic fringe", Pentecostalism achieved greater public acceptance and its leaders were invited to speak at mainline church gatherings to audiences keen for a new sense of spiritual vitality. Many of these mainline church attendees "crossed over into Pentecost" if they felt their own denominations were not moving fast enough toward a new sense of life and relevance. ${ }^{54}$ The Charismatic movement has waned somewhat in recent years, but its impact on the New Zealand church scene was significant in terms of building bridges between denominations and providing a focus for renewal within the mainline churches. In the 1980s and 1990s, independent churches and new denominations like Rhema, Vineyard, and the Christian Outreach Centre emerged. ${ }^{55}$ These churches were examples of the "Third Wave".

\section{The Assemblies of God in New Zealand}

The Assemblies of God did not grow rapidly in the early years. It struggled to gain traction, often meeting in small community halls and club rooms. Many fellowships were comprised largely of working class people with inadequately supported pastors. ${ }^{56}$ The arrival of a number of British pastors between the 1940s and 1960s had a considerable influence on the movement's direction. An analysis of the Council, or Executive, appointments during the years 1927 to 1965 indicates that 53 of the 192 appointments were expatriate Britons. ${ }^{57}$ Ernest T. Mellor arrived in 1929, and was appointed Vice Chairman in 1930. From that time on there was a significant British

\footnotetext{
${ }^{54}$ Knowles, "New Zealand," 190, 191.

${ }^{55}$ Knowles, "New Zealand," 189.

${ }^{56}$ Clark, "Tracing Our Roots," The Evangel, October 1987: 12.

${ }^{57}$ The title of the oversight body changed from Council to Executive in 1944.
} 
influence in the Executive until 1965 when, for the first time, an entirely New Zealand born Executive was nominated. From December 1931 to January 1959 the Chairmanship was also held by British-born pastors. Their contributions were significant, and encompassed the testing periods of economic depression and war during the 1930s and 1940s. ${ }^{58}$ Nevertheless, there is a widespread belief that these pastors had a strong "colonial mentality", and had limited cognisance of a developing New Zealand culture that was not especially sympathetic to older styles of preaching and methods of evangelism, often advocated with a degree of intransigence. ${ }^{59}$ Inflexible attitudes to church administration and organisation and antagonism to Māoritanga may also have significantly hindered the attraction of the movement for Māori. ${ }^{60}$

In the 1950s and 1960s, a group of second and third generation New Zealanders arose as leaders. Dissatisfied with the direction and inflexibility of the movement, two pastors, Frank Houston and Wallace Thompson, resigned from the Executive in 1961. They were called back with promises that the movement would reshape itself around new approaches. Houston's suggestion of more centralised control was rejected. ${ }^{61}$ Out of these conflicts, a more vibrant expression of faith and preaching developed, involving greater cooperation with other churches, and the movement began to grow rapidly.

These changes occurred in the context of new liberalising social movements from the 1960s. ${ }^{62}$ Waning confidence in mainline churches and the social upheaval and

\footnotetext{
${ }^{58}$ Clark, Pentecost at the Ends of the Earth, 44, 255.

${ }^{59}$ Interview with Graham Cruikshank, 25 February 2009; interview with Ken Harrison, 6 November 2008; interview with Ian Clark, 12 December 2008.

${ }^{60}$ Interview with Graham Cruickshank, 25 February 2009.

${ }^{61}$ Clark, "Tracing Our Roots," The Evangel, October 1987: 14.

${ }^{62}$ Ruth Laugesen, "Past Tense," NZ Listener, 11-17 July, 2009: 18.
} 
high unemployment experienced during major government reforms appeared to benefit the Pentecostal churches generally during the 1980s. ${ }^{63}$ The Assemblies of God experienced significant rates of growth, reaching as high as $120 \%$ in 1981 , and only once moving towards 0\% in 1996 as the church experienced the effects of the departure of key leadership to Australia. ${ }^{64}$ The current General Secretary, Neil Hetrick, believes that the present number of attendees is probably closer to 25,000 than the 27,000 projected by the denomination's historian and a former General Secretary, Ian Clark. ${ }^{65}$

The younger New Zealand born leadership became the primary influence within the denomination during the late 1960s and 1970s. Among these, the movement was effectively divided between two "streams". These were based around allegiance to either Neville Johnson, the leader of the very large Auckland Assemblies of God, or Frank Houston, charismatic leader of Lower Hutt Assembly of God. Both were New Zealand born, but differed significantly on certain theological and social issues. Their strong personalities generated equally strong loyalties.

Johnson's parents were English immigrants. He was a proponent of the "Covering" or "Submission" theology, ${ }^{66}$ not in favour of cross-cultural marriages,${ }^{67}$ and totally opposed to divorce and remarriage. He was a member of the Executive from 1971 to 1975, with another brief appointment to replace a departing member in 1976. While he was never Superintendent or Assistant Superintendant, he exercised strong influence over a group of church pastors who voted as a block at General Council

\footnotetext{
${ }^{63}$ Jonathan Harper, “The Church that's Taking Over Auckland,” Metro no. 29 (1983): 122-135.

${ }^{64}$ Clark, Pentecost at the Ends of the Earth, 265.

${ }^{65}$ Based on estimated church attendances by the Assemblies of God. Interview with Neil Hetrick, 23 January 2009.

${ }^{66}$ This required people in ministry to be under the authority of a senior leader.

${ }^{67}$ Interview with Graham Cruikshank, 25 February 2009. Three other people raised specific issues of what they regarded as racism during interviews, but did not wish to be named.
} 
Conferences, held every two years as a part of the National Conference, and who were largely of British origin. ${ }^{68}$

Johnson became pastor of the Auckland Assembly in 1970. His teaching drew crowds from all over Auckland and created one of the largest churches in Australasia at the time. ${ }^{69}$ In 1971, the Evangel announced that "amazing acts of healing and greatly increased attendances" were being experienced. ${ }^{70}$ The census of the same year indicated a $77 \%$ growth in the national church from 2,028 adherents in 1966, to $3,599 .^{71}$

Houston was New Zealand born, identified closely with the New Zealand way of life, worked well with Māori, had no problems with cross-cultural marriages, and had a more liberal view on divorce and remarriage. Though a strong personality, in leadership style and ethos, he was keen to empower others and "release into ministry". ${ }^{72}$ He was General Superintendant from 1967 to $1977 .{ }^{73}$

Houston's influence significantly shaped the movement as a whole. Clark described him as "an outstanding evangelist with a burning desire to see men and women saved and transformed by faith in Christ... moving powerfully in the gifts of the Holy Spirit, with healings and miracles, words of knowledge and discerning of spirits". Clark also credits Houston with the development of a credible evangelistic outreach that thrust the Assemblies to the forefront of the Charismatic movement in New Zealand. ${ }^{74}$ Danny Nalliah's recollections of one of Houston's mission trips to Sri Lanka

\footnotetext{
${ }^{68}$ Clark, Pentecost at the Ends of the Earth, 262; interview with Graham Cruikshank, 13 March 2009.

${ }^{69}$ Interview Graham Cruikshank, 25 February 2009.

70 “Auckland - Queen St," The Evangel, March 1971: 8.

${ }^{71}$ Clark, Pentecost at the Ends of the Earth, 135.

${ }^{72}$ Hazel Houston, Being Frank: The Frank Houston Story (London: Marshall Pickering, 1989), 123.

${ }^{73}$ Clark, Pentecost at the Ends of the Earth, 261-262.

${ }^{74}$ Clark, Pentecost at the Ends of the Earth, 104.
} 
highlighted that Houston's ministry was characterised by demonic deliverance, strong dynamic teaching, simplicity of lifestyle, healings, prophecy, and a suspicion of higher levels of academic learning. ${ }^{75}$

Houston's appointment as Superintendant was followed by significant growth in the movement. ${ }^{76}$ Charismatics and "Jesus Revolution" people began to attend Pentecostal churches, with the Assemblies of God attracting more of these two groups than other denominations, possibly because of the evangelistic thrust by leaders like Houston. A younger group of pastors came through the Assemblies of God's Bible schools. Influenced by the spirit of the times, they were adventurous with nothing to lose and no traditional methods to protect. ${ }^{77}$ The old "siege mentality" began to wane, ${ }^{78}$ and the Assemblies of God began to take up the Latter Rain movements teachings, which had come to New Zealand through the New Life churches. The Latter Rain, influenced by the preaching of United States healing Evangelist William Branham, promoted a strong pre-millennial eschatology that encouraged a confident aggressive evangelism, rather than the "chosen remnant" views of the previous generation. ${ }^{79}$

A new attitude to other churches also emerged and antagonism to ecumenism slowly weakened. In 1967, the Assemblies of God received an invitation from the National Council of Churches to supply a representative to dialogue with a "Spirit filled" theologian from the World Council of Churches. The national conference responded that it could not associate with an organisation with such a broad doctrinal

\footnotetext{
${ }^{75}$ CWM, "Pentecostal Disgrace - Catch the Fire Honouring the Late Frank Houston," http://www.christian-witness.org/blog/?p=6 (accessed March 31, 2009).

${ }^{76}$ Clark, Pentecost at the Ends of the Earth, 117.

${ }^{77}$ Interview with Ian Clark, 12 December 2008.

${ }^{78}$ Clark, Pentecost at the Ends of the Earth, 130.

${ }^{79}$ R. M. Riss, "The Latter Rain Movement," in IDPCM, 830-833; Clark, Pentecost at the Ends of the Earth, 130.
} 
position. Despite this rebuff, the emergence of the Charismatic movement opened the way for ecumenical dialogue in the following years. ${ }^{80}$

The principle of local church autonomy that had been established in 1927 led to a relatively weak national organisation. Churches pooled resources for the support of overseas mission work, and the Executive was also given responsibility for credentialing and disciplining of ministers. Biennial General Council meetings provided opportunities for scrutinizing the work of the Executive and gave a platform for the launching of new initiatives. Yet, in practice, effectively only those activities that served the interests of local churches gained the support of the wider church. This included overseas missions, which were at the heart of the local church. ${ }^{81}$ By contrast, National Evangelists and Bible Training Schools were poorly supported. ${ }^{82}$ As Clark observes, the apparent success of the movement reinforced the emphasis on local church autonomy, since the Assemblies of God is typically the largest Pentecostal church in any country it operates in. ${ }^{83}$

Different models of church governance were evident in the Charismatic movement, and the Ascension Ministries of apostles, prophets, evangelist, pastors and teachers promoted by the Apostolic Church generated some interest. ${ }^{84}$ The major shift, however, came as churches increasingly abandoned congregational government in favour of rule by the pastor and an eldership appointed by him. The movement was slowly transformed from a democracy into an autocracy at the local congregational

\footnotetext{
80 "Lane Adams Crusade, Christchurch," The Evangel, April 1969: 8-10.

${ }^{81}$ Clark, Pentecost at the Ends of the Earth, 128.

${ }^{82}$ Clark, Pentecost at the Ends of the Earth, 128, 136; Ian Clark email to Philip Carew, 22 April 2009.

${ }^{83}$ Interview with Ian Clark, 12 December 2008.

${ }^{84}$ Eph 4:11.
} 
level. ${ }^{85}$ This centralisation of control, however, was not extended to the national church. $^{86}$

Further growth occurred in the 1970s and 1980s, but there were also significant changes. In 1976, Houston expressed his desire to stand down from the Superintendency to concentrate on evangelism and care for pastors throughout New Zealand. He wished to be based in Christian Life Bible College in Lower Hutt. ${ }^{87}$ In 1977, however, he reported that God was leading him to start a new work in an area of Sydney, Australia that had no Pentecostal work. ${ }^{88}$ Houston's influence on the movement was reduced by his move to Australia. He was later required to resign as a pastor from the movement due to previous sexual impropriety. ${ }^{89}$

Jim Williams was one of a number of influential younger pastors who emerged from the Bible Schools in Lower Hutt, Auckland and Tauranga. ${ }^{90}$ Williams was Houston's favoured successor, and followed him as General Superintendant. His dynamic leadership, and regular programme on the newly formed Radio Rhema, lifted the Assemblies of God's profile considerably. As people continued to migrate from the mainline denominations, secular media became more aware of Pentecostal growth. Newspaper reports noted increasing numbers of adherents, striking new buildings, high levels of financial giving, and the upbeat services and theological certainty offered by

\footnotetext{
${ }^{85}$ Ian Clark email to Philip Carew, 28 April 2009.

${ }^{86}$ Clark, Pentecost at the Ends of the Earth, 144-145; Houston, Being Frank, 124-125.

${ }^{87}$ Clark, Pentecost at the Ends of the Earth, 166.

${ }^{88}$ Hazel Houston, One Hundred Men (Wellington: Hazel Houston, 1977), 40.

${ }^{89}$ CWM, “Alleged Abuse - Peter Fowler," http://www.christian-witness.org/aog/pf_nh.html (accessed May 27, 2009); CWM, "Houston's Unmasked," http://www.christianwitness.org/archives/van2002/houston1.html (accessed May 27, 2009); Tanya Levin, People in Glass Houses: An Insider's Story of Life In and Out of Hillsong (Melbourne: Black Inc. 2007), 114. ${ }^{90}$ Clark, "Tracing Our Roots," The Evangel, October 1987: 14. The Tauranga College was the interdenominational Faith Bible College.
} 
these churches. They also highlighted the youthfulness, ethnic diversity, and large numbers of unemployed amongst Pentecostal adherents. ${ }^{91}$

Optimism about the movement and its leadership was undermined by a series of scandals in following years. At a service in the Auckland Assembly of God on 27 April 1983, it was announced that Neville Johnson was guilty of grave misconduct. ${ }^{92}$ This news shattered the confidence of many within the movement and growth slowed for a period. Williams chose to step down that year to allow fresh leadership to come to the fore. He moved to Australia in March 1989, but was required to relinquish his New Zealand credentials in 1993 due to the discovery of sexual impropriety that had occurred during his time as Pastor of the Hamilton Assemblies of God. ${ }^{93}$ Wayne Hughes, who led the large Takapuna Assembly, succeeded Williams as Superintendent in 1983. Ken Harrison from the fast-growing Papakura Assemblies of God took up the position in $2003 .^{94}$

By the end of the century there was a degree of fragmentation within the movement. From the 1990s a number of large, essentially Pākehā, churches left the Assemblies. In 1997, West City Christian Centre left without a detailed explanation, other than it was moving in another direction that the structure of the Assemblies of God would not facilitate. In 2001, Faith Centre Manukau left, and in 2002 Gateway Church Hamilton departed due to dissatisfaction at the handling of the sexual

\footnotetext{
${ }^{91}$ Editorial, "Empty Pews," Wanganui Chronicle, 6 June 1984, 4; Yvonne Van Dongen, "Mainline Churches Lose Out to Vigorous Fringe," and "Pentecostal Building Programme Accelerates," Sunday Times, 31 July 1983, 8.

${ }_{92}$ Clark, Pentecost at the Ends of the Earth, 186.

${ }^{93}$ Clark, Pentecost at the Ends of the Earth, 243, 263.

${ }^{94}$ Wayne Hughes had stepped down as Superintendent due to the ill health of his wife and subsequently left the Assemblies of God ministry due to allegations of sexual impropriety in the 1980s. Chris Barton, "Church Accused of Hiding Allegations of Sex Abuse," The New Zealand Herald, 24 March 2005, http://www.nzherald.co.nz/nz/news/article.cfm?c id=1\&objectid=10116979 (accessed July 4, 2009).
} 
impropriety of Jim Williams. Auckland's Victory Christian Centre left the movement in 2003 due to a number of factors including the influence of the Toronto Blessing. ${ }^{95}$ The departure of these large churches contributed to the changing ethnic demographic of the Assemblies of God.

Another source of fragmentation related to the ethnic diversity that had become characteristic of the Assemblies of God from the mid-1960s, especially in the wake of the Pacific migration of that period. A number of Pacific groups came into New Zealand during the 1960s, establishing ethnically based churches and affiliating with the Assemblies of God. These ethnic assemblies were used to a greater level of centralised control, a feature of the Assemblies of God USA missionary activity in the Pacific, and expected this form of organisation here in New Zealand. ${ }^{96}$

The largest of these ethnic groups is the Samoan Assemblies of God. In 1965, these became part of the New Zealand Assemblies of God, operating as a separate stream within the denomination. By 2003, there were 80 Samoan Assemblies affiliated, and pastors were credentialed through the New Zealand Assemblies of God with churches operating under its constitution. ${ }^{97}$ In 2005, there were 90 Samoan churches, but one third of these left in that year to form a new movement under the leadership of Pastor Samani Pulepule. This group operates under the title of the Samoan Assemblies of God in New Zealand Incorporated.

\footnotetext{
${ }^{95}$ Clark, Pentecost at the Ends of the Earth, 235, 241, 246, 254. The Canadian based revival was known for its ecstatic worship including laughter, shaking, crying and animal manifestations.

${ }^{96}$ Interview with Graham Cruickshank, 25 February 2009.

${ }^{97}$ Clark, Pentecost at the Ends of the Earth, 119.
} 


\section{The Samoan Assemblies}

Given the size of the Samoan constituency within the Assemblies of God, and its particular status within the movement, it is important to understand something of the background of the Samoan assemblies. The Samoan experience also provides a point of comparison in considering the Assemblies of God's relationship with Māori.

The Samoan Assemblies of God started in 1926 in American Samoa as a missionary endeavour of the Assemblies of God USA. ${ }^{98}$ A limited number of missionaries were involved, but early contact was established with Samoan leadership. ${ }^{99}$ The church quickly developed its own distinctive style, including methods of dealing with finance. ${ }^{100}$ The priority placed on establishing indigenous leadership was one of the keys to its success. Within two years of his conversion in 1963, Samani Pulepule was pastoring a church, and within six years of his conversion in 1958, Max Haleck, a Samoan, was superintendent of the Samoan Assemblies of God. ${ }^{101}$ The rapid divesting of leadership from missionary agents to the indigenous community was a significant factor in the churches growth, but a supportive connection with the Assemblies of God's Foreign Missions Department in Springfield Missouri was maintained. $^{102}$

While able to build on the Samoan acceptance of Christianity that extended back to 1830, adherents of the Assemblies of God nevertheless experienced significant persecution in the early years. The willingness of large numbers of Samoans to accept Pentecostalism in violation of directives from village chiefs and councils, and despite

\footnotetext{
${ }^{98}$ Anderson, Introduction to Pentecostalism, 142-143.

${ }^{99}$ Pagaialii, Pentecost "to the Uttermost," 34.

${ }^{100}$ Interview with Neil Hetrick, 23 January, 2009.

${ }^{101}$ Steve Allen, "Viia Le Atua," The Evangel, October / November 1986: 16.

${ }^{102}$ Pagaialii, Pentecost "to the Uttermost," 33.
} 
incurring hefty fines, physical abuse and social alienation, may have been related to wider social processes. Pagaialii's recent history of the Samoan movement provides few clues on these matters. Nevertheless, rapid growth and strong local leadership enabled the church to establish an independent identity quite quickly. Bible colleges and schools were established and relevant literature in the Samoan language produced. ${ }^{103}$ The church currently represents between 7 and $10 \%$ of Western Samoa's population of $214,000 .^{104}$

The Samoan "diaspora" internationalised the Samoan Assemblies of God, physically and to some extent in outlook. ${ }^{105}$ Establishment of the Samoan Assemblies of God in New Zealand closely followed the granting of independence to Samoa and the immigration opportunities afforded by the signing of the Treaty of Friendship in 1962. Samani Pulepule arrived in New Zealand in 1967, and became one of the movement's most influential leaders. ${ }^{106} \mathrm{He}$ regarded the New Zealand work in pioneering terms, which illustrated an essentially independent outlook. ${ }^{107}$ Nevertheless, the rapid growth of the Samoan assemblies caused the Assemblies of God in New Zealand to pay close attention to the movement. ${ }^{108}$ This growth has been attributed to a concentrated focus on evangelism amongst Samoan people by Samoans. Overall, this has played a significant part in the growth of the New Zealand Assemblies of God generally. $^{109}$

\footnotetext{
${ }^{103}$ Pagaialii, Pentecost "to the Uttermost," 41.

${ }^{104}$ World Facts Book, "Samoa (WS)," http://www.enotes.com/world-fact-book/samoa-ws (accessed 30 June 2009).

105 Pagaialii, Pentecost "to the Uttermost," 53.

106 "Pastor Samani Pulepule, Superintendant of the Samoan Assemblies of God in New Zealand," The Evangel, Summer 1991: 30-31.

${ }^{107}$ Steve Allen, "Viia Le Atua," The Evangel, October / November 1986: 16-18.

${ }^{108}$ Interview with Neil Hetrick, 23 January, 2009.

${ }^{109}$ Clark, Pentecost at the Ends of the Earth, 119.
} 
Like other Pacific fellowships, the Samoan assemblies have a stronger sense of cohesion as a movement and greater levels of "centralised" control than the denomination as a whole. This is a function of the earlier Assemblies of God USA's missionary ethos and Pacific cultural values. The Samoan assemblies have a high degree of autonomy. As part of this, it is significant that initiatives for change, such as making a stand against particular aspects of the culture they believed incompatible with Christian teaching, came from within the indigenous church itself. At a congregational level, there has been little interaction between churches in the Samoan stream and the wider Assemblies of God in New Zealand. This has generally been explained by referring to cultural and language difficulties. Nevertheless, Pastor Samai Pulepule, was a member of the National Executive from 1977 to 1997. A permanent seat on the Executive is reserved for the Samoan stream. ${ }^{110}$

\section{The Changing Profile of the Assemblies of God in New Zealand}

The profile of the Assemblies of God in New Zealand has changed substantially since its beginnings in 1927. Denominational publications of the period covered by this thesis indicate an ideologically changing church. Historically, the Assemblies of God saw itself in essentially counter-cultural terms, fellowshipping in smaller churches, and more concerned for the winning of souls than the building of large congregations. ${ }^{111}$ It emphasised personal salvation and the Baptism of the Spirit, was marked by antipathy to the National Council of Churches, and exhibited overt anti-Catholicism as well as

\footnotetext{
${ }^{110}$ Pagaialii, Pentecost "to the Uttermost,"116-123; Steve Allen, "Viia Le Atua," The Evangel, October / November 1986: 16.

${ }^{111}$ This feature was also noted in the early days of the Samoan Assemblies of God. Pagaialii, Pentecost "to the Uttermost," 65.
} 
suspicion of other mainline denominations. A strong emphasis on the imminent return of Jesus was evident, and reinforced by the formation of the State of Israel in 1947, and there was deep scepticism about the value of academic theological study. Creationism was strongly promoted. Teaching on worship emphasised the public expression of the gifts of the Spirit and songs were largely drawn from the "Redemption Hymn Book".

Over time this evolved to embrace a concern for individual's self development in addition to personal salvation. There was an acceptance of the move of the Spirit in the Roman Catholic churches, a greater engagement with other denominations, and appreciation of a greater range of theological perspectives. Interest in mega-church growth reflects a changed attitude to evangelism and church life. There is now a greater emphasis on children's education, and blending of academic research on counselling with Biblical teaching. Some political activism is accepted, and there has been a reduction in commentary on the Israel issue and creationist teaching. Worship became more focused on the singing of contemporary worship songs, as the mega church approach has tended to restrict the manifestation of the gifts of the Spirit in public worship. $^{112}$

There have also been demographic changes. If the church once appealed particularly to poorer or marginalised groups, this was certainly no longer the case by the end of the twentieth century. During the 1970s, doctors, lawyers, school principals, heads of Government departments and large corporations, both national and multinational could be numbered amongst its adherents. ${ }^{113}$ Takapuna Assemblies of God, with an attendance of 1300 , had only two tradesmen and one labourer in the early

\footnotetext{
${ }^{112}$ Based on a review of the Evangel and Empowered Magazines of the Assemblies of God New Zealand, 1968 to 2008.

${ }^{113}$ Writer's observation at Life Point Assembly of God, Wellington in 1993.
} 
1990s, while the rest were largely professionals. Its young people's group included six doctors in their twenties. Denis Acraman, a current Executive member, believes the poor are not well represented in New Zealand's contemporary Pentecostal churches. ${ }^{114}$ In short, the Assemblies of God has become increasingly respectable.

In addition to the qualitative changes evident in the denominational literature, a survey of the movement's churches in the Wellington region was conducted in the course of this research. The survey aimed to provide a contemporary snapshot of the movement by investigating the age of attendees, the regularity of their attendance, the length of time people had been associated with their current movement and evaluating the ethnic composition. The Wellington region was chosen for proximity, but also because its population and ethnic composition roughly equate with the national profile. ${ }^{115}$ Where possible, results have been compared with those published from a national survey the Assemblies conducted in $1992 .{ }^{116}$ Overall, the more recent survey paints the picture of a young, mobile, committed and ethnically diverse movement.

The Wellington region contains 44 , or $16.5 \%$ of the nation's 250 Assemblies of God churches, and 26 of these responded to the survey. ${ }^{117}$ The total number of attendees in this responding group was 2,193 giving an average congregational size of 84 , ranging from 15 to 210 . Of the non-respondents, 17 were Samoan churches and one a Cook Island fellowship that had gone into recess. The majority of the nonreturns were not able to be contacted due to disconnected phone numbers and no

\footnotetext{
${ }^{114}$ Dennis Acraman email to Philip Carew, 5 June 2009.

${ }^{115}$ See "Wellington Region Community Profile," http://www2.stats.govt.nz/domino/external/web/commprofiles.nsf/findinfobyarea/09-rc (accessed 19 March 2009).

${ }^{116}$ Kevin Ahern, "The Season of Harvest," The Evangel, Autumn 1993: 7.

${ }^{117}$ Church lists supplied by the Regional Overseer of the Wellington Region, Pastor Roy Brinck, in December 2008.
} 
responses to emails or phone messages. The most obvious identifiable effect, if the non-respondents are factored, would likely be an increase in the proportion of Samoan adherents, and corresponding reduction in those of other ethnicities.

Attendees were grouped according to age with categories set at 0-16, 17-30, 31-50, 51+ years. Compared with national and regional averages, the church's age composition in the Wellington region is relatively youthful.

Table 1: Age of Attendees

2009 Wellington 2001 Dept of Labour Survey

$0-16$ years

17-30 years

31-50 years

$51+$ years
$29.00 \%$

$21.00 \%$

$31.00 \%$

$19.00 \%$ Wellington Figures ${ }^{118}$

2001 Dept of Labour National Figures

$24.30 \%$

$19.50 \%$

$29.00 \%$

$27.20 \%$

The most striking feature of this data is the concentration in the under 51 classifications. In particular, there seems to be a strong concentration of adherents in the 31 to 50 years age group. In 1992, 60\% were under 30 years old, while the Wellington survey is closer to $50 \%$.

The survey also suggested that attendance is regular, with $90 \%$ attending more than two times per month. Visitors were $4 \%$ of attendees. Other than the "visitor" classification, no analysis was done of the level of commitment of attendees in terms of those who were members and those who were regular attendees only.

\footnotetext{
${ }^{118}$ Department of Labour Wellington Regional Report, "Wellington and New Zealand figures," http://www.dol.govt.nz/PDFs/aidr-wellington.pdf (accessed April 9, 2009).
} 
The length of time those surveyed had been associated with their present church produced a Mean of 8 years, a Mode of 4 years and a Median of 5 years. Three-quarters of attendees had attended a particular fellowship for 10 years or less. Three churches, one quite large, had one person fill out the survey based on their church records. They wrote down a single tenure figure for each person of 4 years as being representative of the time they had been in the church. While this misrepresents the Mode and Median, it may not have affected the Mean, if the figure of 4 truly approximates the number of years associated with this fellowship. Excluding these churches from the figures the Mode was 8 years, the same as the Mean. The range of attendance years was 0 to 70 . A more accurate reflection of the range is probably 0 to 50 as it is suspected that the elderly person who put down 70 may have thought that age was required. The particular fellowship concerned commenced in $1972 .{ }^{119}$

The above statistics tend to indicate a short term commitment to a fellowship. It does, however, need to be noted that the length of time people stay in homes in Wellington is 7.3 years. ${ }^{120}$ Nevertheless, people shift to upgrade, rather than leave the region, continuing to point to short term tenure in fellowships.

For the purpose of this thesis, the data on ethnicity is especially relevant, particularly relating to Māori participation. Māori form an increasing share of the national population, rising from $12.9 \%$ to $14.0 \%$ in 1991 and 2006 respectively. ${ }^{121}$ They currently comprise $12 \%$ of the population in the Wellington region. ${ }^{122}$ In

\footnotetext{
${ }^{119}$ Clark, Pentecost at the Ends of the Earth, 139.

${ }^{120}$ Steve Kendall (Department of Statistics) email to Philip Carew, 22 July 2009.

${ }^{121}$ 2006CensusQSCI, "Ethnic Group (total responses)," Table 2.

${ }^{122}$ Department of Labour "Annual in Depth Report - Wellington Region," http://www.dol.govt.nz/PDFs/aidr-wellington.pdf (accessed June 19, 2009).
} 
numerical terms, the Māori population of New Zealand has grown from 434,847 in 1991 to 565,329 in 2006 , an increase of $30 \% .^{123}$

The survey indicated that the Assemblies of God in Wellington had a slightly higher proportion of Māori than the national survey in 1992, at $8.36 \%$ as compared to 7.1\%. If Wellington conformed to the national situation in 1992, then this suggests a slight increase in Māori participation. The increase is similar to the level of growth in the Māori population in the region generally.

The most striking feature, however, is the increasing ethnic diversity of the Assemblies of God since 1992. Even excluding non-respondents, Samoans now form the largest ethnic group at $34.2 \%$ with Europeans included in the "Other" category at $32.7 \%$. Europeans, Tongans and Tokelauans are the only groups whose share of the church's composition declined.

${ }^{123} 2006$ CensusQSCI, "Ethnic Group (total responses)," Table 2. 
Table 2: Ethnic Composition of the Assemblies of God, 1992 and 2009 With a Comparison to the 2006 National Census Figures

$\begin{array}{lccc} & \text { A/G NZ } & \begin{array}{c}\text { A/G } \\ \text { Wellington } \\ \mathbf{1 9 9 2}\end{array} & \begin{array}{c}\text { National } \\ \text { Census }\end{array} \\ \text { Māori } & 7.10 \% & 8.40 \% & \mathbf{2 0 0 6} \\ \text { Samoan } & 22.90 \% & 34.20 \% & 14.00 \% \\ \text { Fijian } & 0.90 \% & 2.10 \% & 3.30 \% \\ \text { Tongan } & 2.50 \% & 1.70 \% & 1.30 \% \\ \text { Indian } & 1.20 \% & 3.20 \% & 2.50 \% \\ \text { Chinese } & 1.10 \% & 1.50 \% & 3.60 \% \\ \text { Korean } & 0.50 \% & 1.90 \% & 0.08 \% \\ \text { Tokelauan } & 0.30 \% & 0.20 \% & 2.00 \% \\ \text { Other } & 63.40 \% & 46.60 \% & 71.22 \%\end{array}$

Overall, the Wellington survey suggests that the contemporary Assemblies of God appeals to a relatively young, mobile, but committed constituency. Its churches seem to be comprised largely of people in the "under 50" age groups, with a high concentration in the 31 to 50 age range. The church is increasingly ethnically diverse, with Samoan adherents forming possibly the largest single ethnic group. As with the population as a whole, Māori appear to form a larger proportion of attenders than they did in the early 1990s.

This chapter has introduced central characteristics of the Assemblies of God in New Zealand, placing the local denomination within the history of the Pentecostal movement. The Assemblies of God commenced in New Zealand in 1927. Since 1970, the denomination has experienced significant growth and achieved greater social acceptance, leading to a number of changes in emphasis. The movement also became ${ }^{124}$ 2006CensusQSCI, “Ethnic Group (total responses)," Table 2. 
ethnically diverse during this period. Yet, despite this, and despite Pentecostalism's propensity to ethnic diversity, Māori appeared, and still appear as a small, if marginally increasing, minority within the Assemblies of God.

The main focus of this thesis, however, is not simply demographic. It concerns ways the denomination has responded to Māori, especially in the years since 1970. The profile of Māori within New Zealand politics and society altered significantly from around that time. The mainline churches grappled with those changes, and developed structures to reflect perceived responsibilities to Māori. These developments have given rise to both a language and theology of "biculturalism" that will be explored in Chapter Two, before assessing the Assemblies of God's response. 


\section{CHAPTER TWO}

\section{Biculturalism and the Mainline Churches}

Prior to the 1940s, $80 \%$ of Māori lived in rural areas. Mass urbanisation of Māori occurred during and after World War II due to the manpower required for developing New Zealand industry. ${ }^{125}$ This change did not lead to a substantial presence within the Assemblies of God. Nevertheless, it did have a profound impact, both on Māori and New Zealand society more generally. Māori and Pākehā worlds collided in new ways and old assumptions were reconfigured. In particular, longstanding assimilationist ideas gave way to a new language of biculturalism and reform.

These were profound social and political changes that inevitably impacted upon religious life and organisation. In order to adequately identify attitudes to biculturalism within the Assemblies of God, this chapter explores the rise of this new context. It considers the meaning of "biculturalism" as it emerged from the 1970s and investigates the place of Partnership within the bicultural debate. The chapter also explores the way mainline churches have responded to this new milieu, as they confronted the implications of biculturalism in practice.

\section{Biculturalism}

By the 1970s a rising tide of events had brought Māori issues to public attention. Articulate and educated Māori came to the fore, asserting the place the Tangata Whenua in every aspect of New Zealand life. Waitangi Day protests from 1971, the

\footnotetext{
125 "Urban Māori," Te Ara Encyclopaedia of New Zealand, http://www.teara.govt.nz/en/urban-maori/1 (accessed 25 August 2009).
} 
Land March of 1975, and occupations at Bastion Point (1978) and the Raglan Golf course (1978) were all high profile examples of Māori activism during this era. The emergence of Te Kohanga Reo (1982), and Kura Kaupapa Māori (1986), and initiatives like the Māori Education Development Conference (1984), and the Māori Economic Development Conference (1985) signalled that Māori needs and aspirations were gaining increasing political recognition.

The Treaty of Waitangi was central to this renaissance. Embarrassed as a result of protests by Ngā Tamatoa at the 1971 Waitangi Day celebrations, the third Labour Government sought the advice of the Māori Council to determine the root of Māori grievances. ${ }^{126}$ As a result, Prime Minister Norman Kirk, in a speech at the Treaty celebrations on 6 February 1973, declared that this day each year would be a national holiday to be known as New Zealand Day. This idea was put it into effect with the New Zealand Day Act, 1973. Kirk spoke of maintaining the focus and dignity of the Treaty, and indicated the need for Parliament to recognise it by way of statute. This commenced with the passing of the Treaty of Waitangi Act in 1975. Kirk acknowledged the demands that had been placed on Māori, to give up their identity in the interest of the majority and declared his belief that Māori and Pākehā could preserve their culture and identity in the process of working together to build a country of equal opportunities. ${ }^{127}$

The Treaty of Waitangi Act enabled Māori to make claims against the Crown for redress of new grievances, but not historical ones. A flow of legislation followed, aiming at improving the position of Māori, but it was not until 1985 that the fourth

\footnotetext{
${ }^{126}$ Ranganui Walker, Ka Whawhai Tonu Matou: Struggle Without End (Auckland: Penguin, 1990), 210212. The Māori Council had been set up under the Māori Social and Economic Advancement Act 1945 to give statutory recognition to tribal committees.

${ }^{127}$ Bill Jeffries, "Kirk's Prime-ministership, 1972-1974," in Three Labour Leaders: Nordmeyer, Kirk, Rowling, ed. Margaret Clark (Palmerston North: Dunmore Press, 2001), 111-112.
} 
Labour Government amended the Act, allowing Treaty claims to date back to 1840 . In 1985, the David Lange led Government also introduced the Five Principles for Crown Action on the Treaty of Waitangi. ${ }^{128}$ The National government of the 1990 s continued the acknowledgement of Māori grievances with the Resource Management Act, 1991 which took into account Māori cultural values when granting resource consent for development projects. The Health and Disability Services Act, 1993 was a stimulus for health service providers to take into account Māori health requirements. The move to Mixed Member Proportional electoral system in 1996 created greater opportunities for Māori representation and participation in parliamentary political processes. ${ }^{129}$ These changes have been described as examples of "bicultural reformism". ${ }^{130}$

The concept of "biculturalism" arose in the context of this Treaty activism. In 1982, the Human Rights Commission issued a landmark report, Race against Time, which emphasised the need for Māori to be appointed to decision-making positions and to a wider range of employment. It also called for education and training programmes that targeted Māori and petitioned the government to help them find a new pride and identity through the reinvigoration of their language. The Commission called for a reform of bureaucracy, legal systems, and churches, requesting that they be transformed by the addition of a Māori "dimension". It proposed that better arrangements be made for the ownership and control of Māori land and drew attention to the need to cater for

\footnotetext{
${ }^{128}$ Mason Durie, Mauri Ora: The Dynamics of Māori Health (Auckland: Oxford University Press 2001), 52. The principles were: 1 . Principle of government (the kawanatanga principle); 2. Principle of selfmanagement (the rangatiratanga principle); 3. Principle of equality; 4. Principle of reasonable cooperation; 5. Principle of redress.

129 Andrew Sharp, Justice and the Māori: The Philosophy and Practice of Māori Claims in New Zealand Since the 1970's, 2nd edition (Auckland: Oxford University Press, 1997), 214.

${ }^{130}$ Dominic O'Sullivan, Faith, Politics and Reconciliation: Catholicism and the Politics of Integrity (Wellington: Huia, 2005), 211.
} 
Māori women and youth, calling on the media to report the facts on multiculturalism. ${ }^{131}$ The report described a bicultural society as a society of two cultures, where people are sensitive to aspects of two cultures, emphasising that Māori culture is not to be seen as just for Māori but a resource for all of society. ${ }^{132}$

The Commission's reforming agenda employed a language of "multiculturalism", but it gave special consideration to Māori. Legislation such as the Law Commission Act, 1985 referred to, and recognised, some of the force of biculturalism. ${ }^{133}$ The concept emerged more clearly in July 1986 in the Ministerial Advisory Committee's Puao-Te-Atua-Tu / Day Break. This report endeavoured to create an environment acceptable to both Māori and Pākehā within the Department of Social Welfare. ${ }^{134}$

The shift in emphasis from multiculturalism to biculturalism was motivated by the recognition that the concept of multiculturalism had been commonly used as a means of avoiding the "historical and social imperatives of the Māori situation". The report commented that Pākehā needed to understand Māori perspectives and value them, adding that they should understand that Māori saw a history of Pākehā exploitation by force of arms, fraud and mono-cultural law and exhorted that Pākehā cease to counter the reforms "with allegations of separatism or privilege". The Advisory Committee complained of those who cannot conceive that indigenous people

\footnotetext{
${ }^{131}$ Hiwi Tauroa, Human Rights Commission, Race Against Time (Wellington: The Human Rights Commission, Race Relations Conciliator, 1982), cited in Sharp, Justice and the Māori, 214.

132 Tauroa, Human Rights Commission, Race Against Time, 51.

${ }^{133}$ Sharp, Justice and the Māori, 228.

${ }^{134}$ Ministerial Advisory Committee on a Maori Perspective for the Department of Social Welfare, PuaoTe-Ata-Tu (PTAT) / Day Break . Report to the State Services Commission, Public Service in a Multicultural Society. Waahi Conference, 1982 (Wellington: State Services Commission, 1983), 5-11, $15-24$.
} 
have particular rights, or [cannot] contemplate that the denial of a way of life to the original inhabitants, is itself divisive and destructive. ${ }^{135}$

Crucially, the Puao-Te-Atua-Tu / Day Break report highlighted the importance of the Treaty as a driving force in contemporary Māori protest, and its role as a symbol for Māori in determining their relationship with Pākehā. The Treaty had given Māori the rights and privileges of British citizens which they interpreted as "total equality in social, cultural, economic and political spheres of the community." Thus, the Department should "interpret biculturalism as the sharing of responsibility and authority for decisions with appropriate Māori people." ${ }^{136}$ Puao-Te-Atua-Tu set out a mode of "bicultural Distributivism" that included a devolved system of social welfare provision with much more Māori involvement in the localities. ${ }^{137}$

Biculturalism became a central part of the vocabulary that emerged in the study of cross-cultural engagement in New Zealand, along with terms like partnership, assimilation, self determination, Mana Motuhake and Tino Rangatiratunga. A range of models of biculturalism have since arisen. Mason Durie comments that biculturalism has been expressed as a separate Māori way of doing things, a celebration of culture, ensuring a workforce composition to reflect community cultural makeup, or a partnership between Māori and non-Māori. ${ }^{138}$ He refines this further by quoting D. R. Thomas who identified three patterns of bicultural development: the "add on" [the addition of Māori values or customs to a service], the partnership pattern [between a

${ }^{135}$ PTAT, 77-79.

${ }^{136}$ PTAT, 19, 64-66.

137 PTAT, 24.

${ }^{138}$ Durie, Mauri Ora, 166. 
mainstream service and a Māori community], and the parallel development pattern [separate services for Māori]. ${ }^{139}$

Dominic O'Sullivan, quoting Andrew Sharp, classifies biculturalism in two forms: "bicultural distributivism" and "bicultural reformism". In bicultural distributivism, resources are allocated according to the portion a particular group forms of the total population or on the basis of some other formula. Bicultural reformism is expressed as an integration of two cultural perspectives into a hybrid expression. ${ }^{140}$

Irrespective of the model used, Durie identifies key issues that must be considered when looking at what Māori want from the process. First, he argues that biculturalism must be concerned with Māori development and advancement in Māori terms: "It is not for non Māori to decide what is good for Māori; that is a decision for Māori." Second, self determination assumes that Māori wish to live as Māori and not necessarily as Pākehā. Third, programmes implemented must facilitate their access to New Zealand society. They are not to be confined to a ghetto of marginalised existence. Fourth, biculturalism must enhance Māori lives and Māori knowledge. Fifth, it must recognise that they want to retain a distinct identity that comes from a unique heritage, common journeys, a familiar environment, and a set of shared aspirations. ${ }^{141}$

\section{Partnership}

The principle of "partnership" occurs frequently in interpretations of the meaning of biculturalism. The notion is drawn from the idea of "Treaty principles" that emerged

\footnotetext{
${ }^{139}$ D. R. Thomas cited in Durie, Mauri Ora, 167.

${ }^{140}$ Dominic O’Sullivan, Beyond Biculturalism: The Politics of an Indigenous Minority (Wellington: Huia Press, 2007), 16.

${ }^{141}$ Mason Durie, Nga Kahui Pou: Launching Māori Futures (Wellington: Huia Publishers, 2003), 90-91, cited in O'Sullivan, Beyond Biculturalism, 25.
} 
from debate about the Treaty of Waitangi in the 1980s. Partnership is held to be implicit in the Treaty, with the Māori version allowing chiefs to maintain their status as Rangatira and the giving of Kawanatanga, meaning governorship or the responsibility to oversee and administer, rather than sovereignty, to the Crown. ${ }^{142}$

Partnership entails notions of reciprocity and obligation which each partner has toward the other. ${ }^{143}$ For Māori, this is important because it establishes that the Crown cannot ultimately make decisions over their resources. ${ }^{144}$ Durie, however, warns that the greatest limitation of the partnership discourse is that it is frequently not concerned with Māori development and advancement in Māori terms. Māori development and advancement needs to be unmistakably and explicitly the focus of any discussion that will serve their aspirations. Partnership received a definition in Common Law through the case of New Zealand Mãori Council v. Attorney General, 1988 which stated that the Treaty signified a partnership requiring Māori and Pākehā partners to act towards each other reasonably and in good faith. ${ }^{145}$

Other influential organisations also wrestled with the concept of partnership. Claudia Orange argued that the United Nations' work on Human rights from the 1970s had a strong influence, even over and above that of the Treaty, in determining how the term partnership was considered with regard to indigenous peoples. ${ }^{146}$

\footnotetext{
${ }^{142}$ Ruth Smithies, Ten Steps Toward Bicultural Action (Wellington: The Catholic Commission for Justice Peace and Development, Aotearoa - New Zealand, 1990), 38-39, 45.

${ }^{143}$ Merata Kawharu, "Rangatiratanga and Social Policy," in Waitangi Revisited: Perspectives on the Treaty of Waitangi, eds. Michael Belgrave, Merata Kaharu, and David Williams (Melbourne: Oxford University Press, 2005), 106.

${ }^{144}$ O'Sullivan, Beyond Biculturalism, 25.

${ }^{145}$ Mason Durie, "Contemporary Māori Development: Issues and Broad Directions," in Nga Kahui Pou, 90-91.

${ }^{146}$ Elizabeth J. Beatson, "Becoming a Three Tikanga Church: The Bicultural Commission on the Revision of the Constitution 1986-1992," MA Thesis in History, Massey University, 2002, 76.
} 
The concept of "partnership" has not gone unchallenged. Dr Ken Booth's Selwyn Lecture at St John's College argued that the Treaty exists between the State of New Zealand and individual Māori tribes, giving them the rights of British citizens and providing no place for the idea of partnership between the Crown, and Māori as a collective. ${ }^{147}$ This view has not received wide support in the outworking of Government policy or pronouncements. Moreover, it appears to run counter to the early correspondence establishing the basis for the creation of the Treaty, that no British State could be established in New Zealand without the consent of the Māori peoples. ${ }^{148}$

\section{The Mainline Churches and Biculturalism}

Notwithstanding the kinds of objections Booth raised, the mainline churches largely accepted discourses of biculturalism, and moved around the same time, though in slightly different ways, to recognise it. Each had had a heritage of missionary involvement with Māori. ${ }^{149}$ Varying degrees of political consciousness and social obligation arose out of this historical association. Some churches had a history of independent activism or establishment pretensions and were very keen on being socially relevant. Some also had Public Questions committees that were often sympathetic to socially liberal causes. The Anglican, Catholic, Presbyterian and Methodist Churches expressed biculturalism in different ways, each having different

\footnotetext{
${ }^{147}$ K. N. Booth, "A Pākehā Perspective on Tino Rangatiratanga," in Church and State: Te Tino Rangatiratanga: 1996 Selwyn Lectures, ed. Janet Crawford (Auckland: College of St John the Evangelist, 1998), 1-36.

${ }^{148}$ Belich, Making Peoples, 196.

${ }^{149}$ Allan Davidson, Christianity in Aoteoroa: A History of Church and Society in New Zealand (Wellington Education for Ministry, 1991), 133.
} 
levels of participation by Māori and offering varying degrees of autonomy or power sharing to them.

\section{The Anglican Church}

The comparably lengthy association of the Anglican Church with Māori since 1814 and its involvement with the Treaty of Waitangi strengthened its collective sense of responsibility to Māori. Through the agency of the Church Missionary Society, Anglicans were responsible for the translation of the Bible into Māori. Their missionaries learnt the language and set up organisations, committees and boards to participate with them. The church encouraged Māori ministry, which ultimately led to the ordination of Māori Priests and creation of the Diocese of Aotearoa, Māori Bishops and a Māori Archbishop. ${ }^{150}$ It also established Māori Schools. Most significantly, in the era of bicultural awareness, Anglicans reorganised their constitution to establish a Three Tikanga structure in 1992. This aimed to recognise Māori sovereignty over the management of their spiritual affairs. Each member of the Anglican Church in New Zealand and Polynesia has the right to choose which ethnic stream they will fellowship in: Tikanga Māori, Tikanga Pasifika, Tikanga New Zealand. ${ }^{151}$

The Primacy of the Anglican Church is shared by each of the senior bishops of each Tikanga. No major changes can occur in the denomination's constitution or direction without consent of all three Tikanga. They meet together at General Synod every two years. The Māori Tikanga is funded, for core areas of ministry, from land trust incomes, with congregational giving supporting other areas of ministry. All

\footnotetext{
${ }^{150}$ Davidson, Christianity in Aoteoroa, 132-139.

${ }^{151}$ Beatson, "Becoming a Three Tikanga Church," 121.
} 
Anglican priests have training in Māori and liturgies of the Tikanga New Zealand church are in both Māori and English. ${ }^{152}$

Tikanga Māori has some churches, but frequently operates from marae, enabling them to reach a wider Māori community than they otherwise might. Its services are community events that frequently fill the day. These commence with worship and then, after food, there may be times of discussion with church leaders, dealing with a wide range of issues including local social matters and national political issues. A large part of the service is conducted in Māori. ${ }^{153}$ Service attendances, however, are not large. Māori affiliation with the Anglican Church has increased numerically, yet decreased as a percentage from $26.2 \%$ to $13.1 \%$ of the total Māori population between 1971 and 2006. New Zealand's Māori population increased 144\% during this time. ${ }^{154}$

While senior clergy have celebrated the development of the structure, ${ }^{155}$ opposition has ranged from a regret at the absence of Māori in the other Tikanga through to accusations that the system has effectively created an apartheid church. ${ }^{156}$

\footnotetext{
${ }^{152}$ Interview with Bishop Muru Walters, 2 March 2009; Rangi Nicholson, Te Tiriti o Waitangi: Monitoring Maori Language and Cultural Policies of the Anglican Church in Aotearoa, New Zealand and Polynesia, http://www.groupsthatclick.com/files/aams/Nicholson.pdf (accessed April 15, 2009).

${ }^{153}$ Interview with Bishop Muru Walters, 2 March 2009; observation while attending a service at Rota Waitoa, Porirua Anglican Māori Pastorate, 9 August 2009.

154 2006CensusQSCI, Tables 28 and 31; New Zealand Official Year Book, 1975 (Wellington: Statistics New Zealand, 1975), 83; New Zealand Official Year Book, 1992 (Wellington: Statistics New Zealand, 1992), 76.

${ }^{155}$ Whakahuihui Vercoe, “A Self-sufficient Māoridom,” in Vision Aotearoa: Kaupapa New Zealand, eds. Roslie Capper and Amy Brown (Wellington: Bridget Williams Books, 1994), 115; Bishop Muru Walters, Episcopal Unit Report: Te Upoko o te Ika, 2002, in possession of the author; Lloyd Ashton, "The Making of a 'Radical Bishop'," Mana Online, 'http://www.manaonline.co.nz/bishop_vercoe/vercoe2.htm (accessed June 2, 2009); Beatson, "Becoming a Three Tikanga Church," 90-91.

${ }^{156}$ Interview with Archdeacon Peter Benge, 14 September 2009; Marty Sharpe, "Bishop and the Turbulent Priest," The Dominion Post, 8 April 2008: A6; Stuart Scott, The Travesty of Waitangi: Towards Anarchy (Dunedin: Campbell Press, 1995), 88; Beatson, "Becoming a Three Tikanga Church," 2.
} 
Others contend that the model has been adopted by the majority of the church either in a compliant manner, unwilling to question Māori aspirations out of guilt for historical reasons, or out of apathy due to the perception that the adjustments do not affect them. ${ }^{157}$

\section{The Methodist Church}

The Methodist Church, Te Hahi Weteriana, follows a blend of bicultural reformism and distributivism and holds strongly to a Covenant perception of the Treaty. Thus, the report of the New Zealand Royal Commission on Social Policy referred to the Methodist church's belief that "the Treaty is a sacred document which stands alongside the biblical covenants we honour."

Methodism has been operating in New Zealand since the arrival of its first missionary Samuel Leigh in 1822. From 1973, its Māori Mission became the Māori Division of Te Hahi Weteriana. Ruawai Rakena served as its first Tumuaki. In 1983, the Methodists established a Bicultural Committee to encourage the development of a bicultural Methodist church. ${ }^{159}$ This aimed to give Māori and Pākehā an equal voice in the direction taken by the church, and recommended the establishment of a specific group to monitor this process. ${ }^{160}$ If both partners could not agree on an issue no decision was made.

\footnotetext{
${ }^{157}$ Beatson, "Becoming a Three Tikanga Church," 101.

${ }^{158}$ New Zealand Royal Commission on Social Policy, April Report, vol. iii, pt. 1, 'Future Directions' (Wellington: The Commission 1988), 123, cited in Beatson, "Becoming a Three Tikanga Church," 72. ${ }^{159}$ Simon Moetara, "An Exploration of Notions of Māori Leadership and a Consideration of their Contribution for Christian Leadership in the Church of Aotearoa-New Zealand Today," MA Thesis, Laidlaw College, Auckland, 2008, 41; Beatson, "Becoming a Three Tikanga Church," 71, 101-106.

${ }^{160}$ Beatson, "Becoming a Three Tikanga Church," 72.
} 
Although the Māori side of the Church is quite small, resources are divided evenly between the two streams. While each partner gets on with their own vision and development, decisions are communicated to the other partner for information and comment. There appears to be regular communication between the Te Taha Māori and Tauiwi (non-Māori) streams of the church. All key national appointments in the Church are made by a " $4+4$ " team, comprised of four members from Tauiwi stream, and four from Te Taha Māori. ${ }^{161}$ The church's President is chosen by a committee made up of equal numbers of Māori and non-Māori representatives from an equal number of Te Taha Māori and Tauiwi, nominations. ${ }^{162}$

\section{The Roman Catholic Church}

Perhaps because the Roman Catholic Church was not a beneficiary of the Treaty, nor an active advocate for it, it considers no need for structural change to acknowledge a bicultural responsibility. ${ }^{163}$ It does, however, advocate for the State to meet its bicultural responsibilities and actively promotes individual and political solutions. ${ }^{164}$ This advocacy largely occurs through the church's Commission for Justice, Peace and Development. ${ }^{165}$ Representations have been made on numerous pieces of legislation, including the Electoral Law Reform Bill of 1989. The church has moved from not

\footnotetext{
161 Jill Van de Geer email to Philip Carew, 20 July 2009.

162 "Procedure For the Election of President and Vice President," The Laws and Regulations of the Methodist Church of New Zealand - Te Haahi Weteriana o Aotearoa, Section 7:5.1.7.

${ }^{163}$ Orange, Treaty of Waitangi, 57.

${ }^{164}$ Smithies, Ten Steps Toward Bicultural Action, 29.

${ }^{165}$ Smithies, Ten Steps Toward Bicultural Action, 5.
} 
specifying political solutions, to actively promoting policy. ${ }^{166}$ About $10.6 \%$ of Māori are affiliated with Catholicism. ${ }^{167}$

In 1983, the church's Commission for Evangelisation, Justice and Development advised Parliament of "ignorance [about the Treaty] on a major scale" among Pākehā. ${ }^{168}$ In 1985, they produced a discussion booklet of Lenten studies based on the Treaty of Waitangi, entitled New Hope for Society. Despite its long involvement with Māori the Church did not ordain its first Māori Priest until 1944. The first Māori Bishop was appointed in 1988, three years after the Lenten studies. ${ }^{169}$ Historically, a number of Catholic missions had focussed on Māori, the Marist and Mill Hill orders being most notable. ${ }^{170}$ Nevertheless, ministry to Māori had been a secondary concern since the wars of the 1860 s.

The framework for Catholic attention to biculturalism and Treaty issues is largely derived from social justice frameworks that had evolved during the 1940s and 1950s out of concerns regarding the impact of industrialisation on workers. The Second Vatican Council and papal encyclicals such as the Populorum Progressio (1967) addressed broader concerns such as international trade and decolonisation. Liberation Theology also gained a widespread hearing by the 1970s. The Young Catholic Workers actively promoted social consciousness, particularly for Māori and Pacific peoples, and found spokesmen in such people as Manuka Henare and Father John Curnow. ${ }^{171}$

\footnotetext{
${ }^{166}$ O'Sullivan, Faith, Politics and Reconciliation, 205, 226.

${ }^{167}$ 2006Census QSCI, Tables 28 and 31.

${ }^{168}$ Sharp, Justice and the Māori, 109.

${ }^{169}$ Davidson, Christianity in Aoteoroa, 139.

${ }^{170}$ Interview with Father Jerry Burns, 16 June 2009.

${ }^{171}$ Interview with Father Jerry Burns, 22 July 2009.
} 
Dominic O'Sullivan contends that the Catholic Church adopted a more theological basis for "justice" than the Anglican, Methodist and Presbyterian churches, which adopted a more "political" approach by their references to the Treaty. Nevertheless, the desired outcomes were similar. ${ }^{172}$

\section{The Presbyterian Church}

In 1952, a special Presbyterian General Assembly presented a comprehensive report on Māori development, race relations and the future of the church. The Assembly gave its Māori Mission, Te Hinota Māori, interim Presbyterial powers until 1956 when these were upgraded to Synodial authority. As Te Aka Puaho, the new synod assumed responsibility for all Māori Presbyterian work.

The office of Te Aka Puaho is now centred in Whakatane with its own marae at Ohope. ${ }^{173}$ It comprises 13 parishes and offers an Amorangi Ministry Training Programme, “Te Wānanga a Rangi”, along with an Eldership training programme, also based at Ohope. ${ }^{174}$ Training programmes initially had teething problems but developed in addressing the needs of Māori due to the foresight of the notable Māori missioner, John Laughton. ${ }^{175}$ In 2007, Te Wānanga a Rangi began to expand its range of programmes to include a Certificate in Te Aka Puaho Studies, an Advance Certificate and a Diploma, open to all people, not just Amorangi candidates.

\footnotetext{
172 O’Sullivan, Faith, Politics and Reconciliation, 212-213, 231.

173 The Presbyterian Church of New Zealand, "The Presbyterian Church and Māori Mission," http://www.presbyterian.org.nz/archives/page15.htm (accessed 21 July 2009); The Presbyterian Church of New Zealand “Amorangi," http://www.presbyterian.org.nz/national-ministries/knox-centre-forministry-and-leadership/amorangi (accessed July 21, 2009).

${ }^{174}$ Amorangi are locally ordained ministers.

${ }^{175}$ Peter Webster, Rua and the Māori Millennium (Wellington: Victoria University Press, 1979), 30-50; Davidson, Christianity in Aoteoroa, 136.
} 
Members of Te Aka Puaho go to the Presbyterian Theological Hall in Dunedin to deliver intensives on Māori church history, ministry in a Māori context and Treaty of Waitangi issues. All ministerial trainees are required to have exposure to Māori culture, protocol and spirituality, and time is taken for guided reflection on aspects of theology and ministry important for Māori people and communities. ${ }^{176}$

Despite these developments, in 1994 James Irwin provided a less than favourable and emotive interpretation of Presbyterian work with Māori to that point. ${ }^{177}$ Irwin's doctoral thesis accused the Presbyterian Church of treating Māori as inferior people and seeking to undermine and destroy the integrity of their culture. With this in mind, Irwin was suspicious of the church's official bicultural policy. While complimenting individual European missionaries working among the Māori, he argued that their efforts were largely thwarted by the Māori Mission Committee of the Presbyterian Church of New Zealand throughout its history. Irwin contended that the General Assembly did not take its Māori members seriously, and complained about the amount of money put into Māori work. A long-time missionary himself, Irwin accused the Presbyterians of treating their missionaries shabbily and "shamelessly taking advantage of their "call" to this mission work by paying them barely enough to cover the assorted requirement of life."

He argued that positive affirmation of the Treaty of Waitangi was derived from expediency rather than conviction, "for fear of the true attitudes being exposed around the $150^{\text {th }}$ anniversary celebrations of both the Presbyterian Church of New Zealand and

\footnotetext{
${ }^{176}$ Presbyterian Church, “Amorangi," http://www.presbyterian.org.nz/4755.0.html (accessed June 3, 2009).

${ }^{177}$ James Irwin, "The Rise and Fall of a Vision: Māori in the Midst of Pakeha in the Presbyterian Church of New Zealand," PhD Thesis in Religious Studies, Victoria University of Wellington, 1994.
} 
New Zealand itself." He did not undermine the underlying premise of Presbyterian mission work, to build up the Kingdom of God, but accused the church of being stinting in its willingness to invest in the work. ${ }^{178}$

The Presbyterian Church had not come to New Zealand with a missionary intent but to minister to primarily Scottish settlers. Its work amongst Māori was confined largely to the Tūhoe people and in the Bay of Plenty region, ${ }^{179}$ and developed accidentally. ${ }^{180}$ The ancillary nature of this association and Irwin's observations may account for Māori being only $5.3 \%$ of the church's affiliation. ${ }^{181}$

\section{Missionaries, the Crown, and the "Very Sacred Deed"}

The process of dealing with perceived bicultural responsibilities did not come easily for the mainline churches, but the sense of necessity to persevere prevailed largely due to their historical association with Māori. While expediency and the prevailing political climate may have been important, these churches had additional reasons to engage with biculturalism and the principles of the Treaty. In particular, the perceived imperative to accommodate Māori with some expression of biculturalism was often influenced by the idea of the Treaty as a sacred covenant.

The British Crown, subject to financial pressure in other areas of its empire, had been reluctant to formally annex New Zealand and was initially content to simply acknowledge the country's Declaration of Independence in 1835. It eventually bowed

\footnotetext{
${ }^{178}$ Irwin, "The Rise and Fall of a Vision," 1-2, 81.

${ }^{179}$ Webster, Rua and the Māori Millennium, 30-50.

${ }^{180}$ Loren Robb, ed. Te Hinota Māori: The Māori Synod and Māori Spirituality and Ministry (Wellington: Presbyterian Church of Aotearoa New Zealand, 1992), 12-13.

${ }^{181}$ 2006CensusQSCI, Tables 28 and 31; '1966 and 1971 Māori Religious Affiliation figures,' Christine Dean (Department of Statistics) email to Philip Carew, 1 October 2008.
} 
to circumstance and pressure, including that exerted by evangelical humanitarians. ${ }^{182}$ In 1840, it was the evangelical missionaries in New Zealand who actively encouraged Māori to sign the Treaty of Waitangi, largely out of a concern to see their welfare protected through the power of British law. ${ }^{183}$ British commercial agents were also keen to see sovereignty in the hands of the Crown. If this could be achieved via evangelical influence, well and good, but they expressed no great love for the missionaries. ${ }^{184}$

It seems certain that Māori acceptance of the Treaty was at least partially inspired by missionary guidance. Significantly, records of events frequently record Māori using the language of "Covenant" to describe their perception of the importance of what was occurring under the Treaty. ${ }^{185}$ During the negotiations, Māori were assured that land would never be forcibly taken and that chiefly authority would not be undermined. Queen Victoria's role was portrayed as that of a highly moral maternal matriarch who had Māori interests at heart. The solemnity and earnestness of the process caused one chief to comment that the Treaty must be a "very sacred deed!"186

British commercial agents, while pleased to have the colonisation formalities completed, regarded the Treaty as "little more than legal fiction," 187 and had little time for the missionary community once the Treaty was signed. Missionary concerns for the Māori and Treaty compliance were seen by them as an obstacle to progress. ${ }^{188}$ The "Land Grab" that followed involved both church and commerce. While the church was eventually judged to have acted legally, Governor Grey moved to curb the rate of its

\footnotetext{
182 Orange, The Treaty of Waitangi, 32; Belich, Making Peoples, 134, 194; Ruth Naumann, Lyn Harrison and Te Kaponga Winiata, Te Mana o Te Tiriti (Auckland: New House Publishers Ltd, 2004), 19-20.

${ }_{183}$ Davidson, Christianity in Aoteoroa, 24-25.

${ }^{184}$ Bay of Islands Observer, 7 July 1842, cited in Orange, The Treaty of Waitangi, 91.

${ }^{185}$ Davidson, Christianity in Aoteoroa, 57; Orange, The Treaty of Waitangi, 90.

${ }^{186}$ Orange, The Treaty of Waitangi, 64-65.

${ }^{187}$ Davidson, Christianity in Aoteoroa, 26.

${ }^{188}$ Orange, The Treaty of Waitangi, 26.
} 
land purchases. In any case, in their totality, immigrant land acquisitions came to be seen as violations of the provisions and intent of the Treaty in the eyes of many Māori. War with the Europeans followed in the 1840s as a consequence of the deep sense of betrayal. $^{189}$

Missionaries are generally regarded as having been well intentioned. In their desire, however, to get the Treaty signed, they emphasised positive aspects and understated less favourable consequences of signing. ${ }^{190}$ Increased migration and the advent of war tore missionaries between perceived responsibilities to the newly arrived immigrants and those to Māori. They were aware, not only of the erosion of both Māori land holdings and their associated sovereignty but also that Māori who resisted the sale of land to Europeans were being actively provoked to war. ${ }^{191}$

Māori had shown themselves to be ardent travellers, astute commercial agents, and adept agriculturalists with a penchant for technology. ${ }^{192}$ Yet within twenty-four years of the Treaty's signing they were being significantly dispossessed of their land, decimated by disease and demoralised by relentless waves of immigration that swamped their land. Within a short space of time forty pieces of legislation directly aimed at taking land off the Māori in violation of the Treaty had been passed. ${ }^{193}$

By 1856, the marginalised state of Māori led Isaac Featherston, the Superintendent of the Wellington Province to postulate the need to, "smooth the dying

\footnotetext{
${ }^{189}$ Orange, The Treaty of Waitangi, 117; Jock Phillips, "Māori People of New Zealand," in Te Ara: The Encyclopedia of New Zealand (Auckland: David Bateman, 2006), 262-263; Davidson, Christianity in Aoteoroa, 26; Naumann, et. al., Te Mana o Te Tiriti, 37.

190 “The Christian missionaries Agents of Virtue," http://www.nzhistory.net.nz/culture/the-missionaries (accessed September 24, 2008); Belich, Making Peoples,136, 194-195.

${ }^{191}$ Davidson, Christianity in Aoteoroa, 39; E. A. Powell, Prophecy Speaks: Dissolving Doubts (Washington: Review and Herald Publishing Association, 1933), 66-67; Orange, The Treaty of Waitangi, 122-23.

${ }_{192}$ Davidson, Christianity in Aoteoroa, 39; Orange, The Treaty of Waitangi, 131-135.

${ }^{193}$ Naumann, et. al., Te Mana o Te Tiriti, 47.
} 
pillow of Māori." ${ }^{194}$ But Māori did not die out. Numbers eventually began to increase, and in recent years they have made steady improvement in a wide range of social indicators. ${ }^{195}$ While historical reviews are frequently contested, the Mana Māori Resurgence of the 1970s caused many, including churches, to look at the treatment of Māori during the colonisation process and to search for ways of addressing their evident disempowerment.

For the churches, the realisation that Māori referred to the Treaty in Covenantal terms was significant. It provided a way to deal with the narrative of Crown-Māori relations described above, and that became a dominant discourse in later decades of the twentieth century. The notion of Covenantal responsibility also provided a way to interpret missionary activity, and later weakening of Christian influence among Māori. Within evangelical and Charismatic communities in particular, supporters of this position often referred to the covenant which the biblical leader, Joshua, was tricked into making with the Gibeonite people, and his need, despite trickery, to honour it. 400 years later, this particular treaty was broken by King Saul before he died and God brought judgement on the land of Israel for the breach. It was King David who, after the death of Saul, rectified the situation by asking the Gibeonites what compensation they required. ${ }^{196}$

Covenant is a matter treated with great seriousness in the Bible and is regarded as more than a contract, where a breach of a condition may render it void. ${ }^{197}$ Rather, mana, or dignity, is maintained by a party's ability to maintain their side of the

\footnotetext{
${ }^{194}$ Davidson, Christianity in Aoteoroa, 40.

${ }^{195}$ Ministry of Social Development, The Social Report: Te Pürongo Oranga Tangata 2008 (Wellington: Ministry of Social Development, 2008), 128-130.

${ }^{196}$ Joshua 9; 2 Samuel 21.

${ }^{197}$ Ezekiel 17: 15-21.
} 
agreement in the face of a breach by another party. ${ }^{198}$ The Gibeonite narrative provided a particularly powerful model for New Zealand Christian interpreters, as it described a covenant that remained potent despite the passing of many centuries. The biblical text's emphasis on the social consequences of failure to keep covenant seemed particularly apt in the context of late twentieth-century social upheaval. Lloyd Martin's book, One Faith, Two Peoples, which was widely promoted among evangelical and Charismatic groups, encouraged this understanding. ${ }^{199}$ The Gibeonite narrative seemed particularly congenial to these groups' hermeneutical approaches.

The rise of Treaty activism was the critical element in the emergence of discourses of biculturalism from the 1970s. The idea of partnership figured prominently in interpretations of the intent of the Treaty, and subsequently became central in thinking about "Treaty principles" and models of bicultural engagement. This chapter has demonstrated that the mainline churches, seeking to be communities of ethical responsibility, sought ways in which to honour the Treaty. They did this variously, by speaking out on issues of social justice, institutional restructuring, and accommodating diverse manifestations of biculturalism. The fact of missionary involvement with the Treaty, coupled with decreasing influence among Māori added impetus to this sense of necessity to respond to injustice toward Tangata Whenua. The idea of the Treaty as a “covenant" provided an important rationale and interpretive framework for some Māori and also to certain church traditions. In particular, the model of the Gibeonite covenant

\footnotetext{
1981 Chronicles 16: 7-36.

${ }^{199}$ Promise Keepers circular email to Philip Carew, 4 February 2009.
} 
holds special appeal to sections within evangelical and charismatic traditions. While by no means exhausting the possible ways of engaging with biculturalism, the arguments and actions of the mainline churches provides a point of comparison for responses within the Assemblies of God. 


\section{CHAPTER THREE}

\section{Biculturalism and the New Zealand Assemblies of God}

From the 1970s the mainline churches showed evidence of adapting to the new social and political environment, and were actively confronting issues of biculturalism. This chapter assesses evidence of Māori participation in the Assemblies of God, and the character and extent of its engagement with bicultural ideals. It suggests that, with a few exceptions, Māori participation in the Assemblies of God was sporadic, and that efforts to address this situation were limited. The church occasionally recognised that Māori involvement in the movement was limited, particularly during the period of more intense socio-political activism in the late 1980s. Similarly, there were signs of a desire to remedy this absence. Overall, however, there was overt resistance to notions of biculturalism and the expressed emphasis on multiculturalism was maintained. Many pastors were involved with localised individuals and groups of Māori in the course of their pastoral work. Their reflections provide some insight into the nature of pastoral expectations in terms of cross-cultural ministry. By and large, the prevailing ideology of the Assemblies of God has meant that development of work among different ethnicities in New Zealand has come from within the ranks of individual cultural groupings, rather than as a consequence of an organisational focus on cross-cultural mission activity.

\section{Māori and the Assemblies of God to 1970}

Emphasis on the miraculous has frequently attracted Māori to Pentecostalism. The first recorded interaction of the Assemblies of God and Māori was in 1928 when British 
Assemblies of God evangelist, Stephen Jeffries prayed for a Māori Chief who was dying of cancer. He got up from his bed and walked shouting "I'm healed!" Many converts were said to have resulted from this encounter. ${ }^{200}$

The church's urban focus in the 1920s and 30s tended to hinder its association with Māori. Until the post World War II years, Māori were largely living in rural areas. $^{201}$ The church's urban focus was highlighted at the Assemblies of God's inauguration in Wellington on 22 April 1927 when representatives from Wellington, New Plymouth, Palmerston North and Christchurch fellowships were present. ${ }^{202}$ No rural fellowships were represented and the Assemblies of God continued with a largely urban or city focus. ${ }^{203}$ Language barriers also played a part in limiting contact with Māori in the early years. According to Irwin, it was only in 1941 that most spoke some English, with Māori still the language of the home. ${ }^{204}$ Being primarily an urban "spiritual renewal movement" rather than a missionary one in a country that had become predominantly European, Māori were largely overlooked. ${ }^{205}$

By the late-1960s the Apostolic, Open Brethren and Indigenous Pentecostal churches had successfully established connections with Māori, but the Assemblies of God had not. Graham Cruickshank was an Assemblies of God missionary to Fiji and Tonga between 1966 and 1976, and is currently Senior Pastor of the Christian Renewal

\footnotetext{
${ }^{200}$ Clark, Pentecost at the Ends of the Earth, 43. Similar encounters occurred in Samoa. On this, see Pagaialii, Pentecost "to the Uttermost," 35.

201 "Urban Māori," Te Ara: The Encyclopaedia of New Zealand http://www.teara.govt.nz/NewZealanders/MāoriNewZealanders/UrbanMāori/1/en (accessed April 21, 2009).

${ }^{202}$ Clark, Pentecost at the Ends of the Earth, 34.

${ }^{203}$ New Zealand Assemblies of God, "Find a Church," http://www.agnz.org/about/findachurch/ (accessed June 17, 2009).

${ }^{204}$ Irwin, "The Rise and Fall of a Vision," 215-216. Hazel Houston, Being Frank: The Frank Houston Story (London: Marshall Pickering, 1989), 104.

${ }^{205}$ King, Penguin History of New Zealand, 283; interview with Neil Hetrick, 23 January 2009.
} 
Fellowships whose adherents are 90\% Māori. ${ }^{206}$ Cruickshank toured New Zealand while on missionary deputation, and made an assessment of the church's engagement with the Tangata Whenua.

Reflecting on that period, he contends that many individual Assemblies of God churches tried hard to establish contact with Māori, but were hindered by a lack of empathy with them at National and Regional Council levels. Style and attitude were, in his opinion, key to engaging with Māori. He posed particular questions to be asked regarding association with Māori, such as: Do you like them? Do you try to use their language, even a little? Are the songs you sing in a style suitable for a guitar? Are there power dynamics: healings, miracles, breaking of curses, baptisms in the Holy Spirit, exorcisms involved in your ministry? Cruickshank's home church always had testimonies on Sunday nights. This suited the marae style of korero where anyone could get up and share.

Cruickshank drew attention to the number of English immigrant pastors in positions of influence prior to the mid-1960s, both on the Executive and on the Regional councils. It was highly significant, in his view, that the New Zealand Assemblies of God did not really grow until a New Zealand born Superintendent became leader, seeing this as a manifestation of a "well proven mission principle" that as a rule, people of the nation are the best to lead their people. Māori memory of the historical British land acquisition issues and the sense of a patronising attitude toward them as a "native" race by the English may also have restricted engagement. ${ }^{207}$

\footnotetext{
${ }^{206}$ Interview with Graham Cruickshank, 13 April 2009.

${ }^{207}$ Interview with Graham Cruickshank, 25 February 2009.
} 
Continuing issues relating to order and governance dogged the movement prompting many to join the Apostolic Church in the 1930s with its more structured system of prophets, apostles, evangelists, healers and teachers. ${ }^{208}$

\section{Two Exceptions}

Two particular churches commencing within twelve months of each other had a markedly different impact on the Assemblies of God nationally in terms of the churches' connection with Māori. Ray Bloomfield's Ellerslie-Tamaki Faith Mission affiliated with the movement in 1954 and the Whangarei Assemblies of God in $1955 .{ }^{209}$ A significant experience of the Whangarei Assembly in the 1970s will be discussed later in this chapter.

According to Clark, Bloomfield was a unique individual with a remarkable measure of faith, generosity and Holy Spirit power. His preaching was simple, yet relevant to people and their needs. People travelled considerable distances to be healed, saved and baptised in the Holy Spirit. These services had a significant impact as visitors from as far as Northland made "decisions for Christ". 210

It was during this time that Bloomfield was introduced to Frank Houston. Houston was a Wanganui-born former Salvation Army officer who had been "baptised in the Holy Spirit" a short while earlier. He had had a number of nervous breakdowns prior to this but was reputedly healed, physically and emotionally, through the experience. ${ }^{211}$ Bloomfield and Houston became leaders in a revival movement that

\footnotetext{
${ }^{208}$ Clark, Pentecost at the Ends of the Earth, 50.

${ }^{209}$ Interview with Graham Cruickshank, 25 February 2009.

${ }^{210}$ Houston, Being Frank, 91-100.

${ }^{211}$ Clark, Pentecost at the Ends of the Earth, 89.
} 
occurred at Waiomio near Kawakawa in Northland in $1957 .{ }^{212}$ Māori who had been converted in Ellerslie meetings invited the two men to preach in Waiomio. ${ }^{213}$ Three women in the area had been praying for revival for some time. ${ }^{214}$ In one location Bloomfield and Houston arrived, they were not made to feel welcome. Bloomfield preached and invited people to respond to his message. People's suspicions changed when an elderly identity was healed of a physical disability. Many more went forward for healing and salvation. This launched a revival that saw every family in the valley except one, that of the local tohunga, make Christian commitments over the following weeks. ${ }^{215}$ According to Clark, "The valley, which had been notorious for drunkenness, was transformed into a place of harmony." Building on this event, others, including Noel Watson, Bruce Uren, Russell Ferguson and Malcolm and Bernice Tweed, continued to work with Māori in many parts of Northland. ${ }^{216}$ Ferguson in particular, worked in difficult conditions and at great personal sacrifice. ${ }^{217}$

Indications are that Bloomfield and Houston showed sensitivity toward Māori in their ministry. A welcome in Māori was given at the beginning of the Ellerslie Mission services and they both learnt a few Māori phrases to use in their ministry; interpreters were used for the Northland services; they happily followed welcoming and sleeping protocols in the Northland communities; there was also willingness, somewhat reluctantly, to allow a Māori group to break away from the Ellerslie Mission, some of whom later returned. While enthusiastically working with Māori Houston once

\footnotetext{
212 “Kawakawa Assembly,” The Evangel, April 1969: 12.

${ }^{213}$ Brett Knowles, "Bloomfield, Ray,” IDPCM, 436.

${ }^{214}$ Interview with Jim Prime, 6 May 2009.

${ }^{215}$ Houston, Being Frank, 95.

${ }^{216}$ Clark, Pentecost at the Ends of the Earth, 89-90.

${ }^{217}$ Interview with Graham Cruickshank, 25 February 2009.
} 
exclaimed, "Who said God was an Englishman anyway?" The statement hints at the predisposition amongst Pākehā toward a "European" gospel. ${ }^{218}$

The Waiomio Revival was not maintained due to a number of factors including a lack of follow up; there was no one sufficiently familiar with the culture to guide adherents through the engagement of Māoritanga with Christianity and no development of Māori leadership was apparent. ${ }^{219}$ The "Jesus only" teaching, which regarded Jesus Christ as the equivalent of the "The Father, the Son, and the Holy Spirit", ${ }^{220}$ had a significant impact on the Waiomio community. From the denomination's perspective, this had the effect of disconnecting the area from established teaching and led into syncretisatism, or incompatible combining of aspects of Māoritanga with the Christian faith.

While Fergusson and Tweed worked with Northland Māori, jealousy arose over the success of one over the other. ${ }^{221}$ There was also doctrinal division between the two, with one promoting the church's line of "Trinitarian Baptism",222 and "local church autonomy" and the other leaning toward a combination of the "Jesus only" and "Ascension" theology. ${ }^{223}$ In addition the supervisor of the Northland work, Noel Watson, developed a "questionable relationship with a local woman" and his credentials lapsed after he refused to respond to directives from the Executive on the

\footnotetext{
${ }^{218}$ Houston, Being Frank, 85, 99, 100, 102, 104, 106.

${ }^{219}$ Interview with Ken Harrison, 6 November 2008; interview with Jim Prime, 6 May 2009.

${ }^{220}$ D. A. Reed, "Oneness Pentecostalism," in IDPCM, 937; Acts 2:38, Romans 6:3, Galatians 3:27.

${ }^{221}$ Interview with Jim Prime, 6 May 2009; Clark, Pentecost at the Ends of the Earth, 107.

${ }^{222}$ Baptism in the name of the 'Father, the Son and the Holy Spirit,' after the model of Matthew 28:19.

${ }^{223}$ Interview with Jim Prime, 6 May 2009; Clark, Pentecost at the Ends of the Earth, 107. Ascension theology refers to a form of church government expressed though the offices of Apostles, Prophets, Evangelists, Pastors and Deacons. See Worsfold, A History of the Charismatic Movements in New Zealand, 241.
} 
matter. ${ }^{224}$ The final factor appears to be the failure to build relationships with Kaumātua or marae in the local areas. This was found to be of great importance in Apostolic Church's Māori work and highlights the greater dimension of "community dynamic" in the faith journey for Māori, rather than the distinctly individualistic European approach to faith. $^{225}$

Houston replaced Bloomfield at the Ellerslie Church after Bloomfield shifted to Canada. ${ }^{226}$ Houston's wife, Hazel, makes no mention of the Waiomio revival being considered in relation to her and her husband's decision to move to Lower Hutt from Ellerslie. This is notable in the light of the numbers of people who had responded to Houston and Bloomfield's preaching in both Waiomio and Ellerslie. ${ }^{227}$

The Waiomio experience is often held up as a significant encounter with Māori, but cannot be regarded as "bicultural". The event occurred before the rise of Mana Māori in the 1970s and many of the concepts associated with the issue had not yet taken shape. Empowerment of Māori, in terms of autonomy, does not appear to have been a feature at Waiomio. Houston and Bloomfield's primary focus was evangelism, with an earnest desire to connect with people - any people, whether Māori or not. It was fortuitous rather than planned that their ministry also exhibited characteristics identified as appealing to Māori: strong clear preaching, the signs and wonders of "Power Evangelism", and a particular style of prayer, praise and worship. ${ }^{228}$

On a national basis, Cruickshank considers that patronising attitudes toward Māori were also a factor within the movement in the 1960s. At the time of his

\footnotetext{
${ }^{224}$ Clark, Pentecost at the Ends of the Earth, 106-107.

${ }^{225}$ Interview with Araiti Remuera, 20 February 2009.

${ }^{226}$ Houston, Being Frank, 80-100.

${ }^{227}$ Knowles, "Bloomfield, Ray," 435-436.

${ }^{228}$ Manu Pohio, "Harvesting is Hard Work," The Apostolic News, March 2001: 2.
} 
appointment as a missionary to the Pacific in 1996, the National Executive expressed their support of his appointment saying he had the "Makings of a good missionary character and enthusiasm, with a love for God's Word". 229 Despite this, people associated with Neville Johnson's "covering" raised questions about the impact on his effectiveness due to his marriage to Tui (Ngati Kahungunu, Ngāpuhi, Ngati Whatua). ${ }^{230}$

The cohesion of the movement depended on holding the pastors together. ${ }^{231}$ This became more of a challenge in the 1960s and 70s with the increasing ethnic diversity of the movement's churches and the associated cultural and linguistic differences. The Samoan group grew exceedingly rapidly and by 2009, despite losing one third of its members through secession, is possibly the largest single ethnic group within the Assemblies of God in New Zealand. This is the only ethnic group with a specific seat on the National Executive and the church is aware that this greater ethnic representation may have to be considered in light of the increasing level of diversity within the church. ${ }^{232}$

\section{Māori and the Assemblies of God from 1970 to 2008}

Up to 1970 there was no established ongoing "Māori work" by the church, nor any significant cultivation of Māori leadership. Yet the church was caught up in a society that was addressing the bicultural issue and from this time on there was an increasing attention regarding Māori related issues by the church. This attention took two different forms; a reaction against Māoritanga, and a bemused questioning of issues and their ramification for the church. Despite this new attention, Māori did not occupy a

${ }^{229}$ Clark, Pentecost at the Ends of the Earth, 117-118.

${ }^{230}$ Interview with Graham Cruickshank, 25 February 2009.

${ }^{231}$ Clark, Pentecost at the Ends of the Earth, 147.

${ }^{232}$ Interview with Ken Harrison, 6 November 2008. 
prominent position, and appeared only infrequently in official church publications like The Evangel and Empowered magazines. Between 1970 and 2008, only eleven articles in these addressed an overtly Māori-related issue, or suggested significant Māori activity in a church or at an event. Twenty-two indicative articles suggested possible Māori presence in a church or at an event, and seven insignificant articles included a picture or name of a Māori person.

\section{The Whangarei Assembly of God}

Repeal of the Tohanga Suppression Act, 1907 in 1963, the Land March of 1975, and the Treaty of Waitangi Act 1975 were significant catalysts for change in public perception of Māori issues provoking responses from sections of the Christian community. In May 1976, attention surrounded a front page article in the Northern Advocate entitled "Petition calls for ban on Māoritanga 'demon' lessons in Schools". 233 The petition was promoted by an English member of the Whangarei Assemblies of God, George Anderson. Anderson was so concerned about Māoritanga that he felt it necessary to rip up lino to see if there were any newspapers with Māori images on them. Māori designs on 10 cent pieces meant they could not be used. According to Cruickshank, who was at the time a recently arrived member, strong preaching against Māori spirits and spurious references to the cursing of the descendants of Ham were flowing from the pulpit of the Whangarei Assemblies of God. ${ }^{234}$

The pastor of the church, Geoff Lloyd, was "under the covering" of Neville Johnson and both supported the petition. The National Executive of the Assemblies of

\footnotetext{
233 “Petition Calls for Ban on Māoritanga 'Demon' Lessons in Schools," Northern Advocate, 6 May 1976, 1.

${ }^{234}$ Interview with Graham Cruickshank, 25 February 2009.
} 
God and the Association of Pentecostal Churches, however, distanced themselves from it. Johnson expressed considerable annoyance at this to the secretary of both organisations. ${ }^{235}$

The intention was to present the petition to the Minister of Education, Mr Gander, with its three alternative goals:

1. To stop the teaching of Māoritanga in schools.

2. To restrict the teaching of Māoritanga to such "non spiritual" aspects of the culture as fishing and agriculture.

3. To allow parents to withdraw their children from such classes.

The construction of fishing and agriculture as "non spiritual" aspects of the culture, drew attention to a profound misunderstanding of Māori "spirituality". It also highlighted assumptions about Pākehā views of religion and spirituality - that there is not, in practice, an intimate correlation between daily activities of life and the spiritual. ${ }^{236}$

The debate surrounding the article in the letters to the editor and follow up articles revealed the deep hurt among Māori, many of whom believed that their identity and self respect had been challenged. Central to the offence taken by Māori was that the church had not talked the matter over with Kaumātua before going public. One particular response stated that Māori had accepted Christianity in large numbers and shown a great deal of commitment to the faith, with those accepting Christianity no longer attributing spiritual significance to aspects of the culture that were of concern to the Assemblies of God. It called on the Church to trust Māori to be able to reconcile

\footnotetext{
${ }^{235}$ Interview with Ian Clark, 12 December 2008.

${ }^{236}$ Royal, ed. The Woven Universe, 24-53.
} 
the contentious issues of faith and culture. ${ }^{237}$ Another article in the local newspaper reported the comments of Kaumātua who said that in Christianity they found the faith that had been held in the most sacred stories of their own culture. ${ }^{238}$ Another called on Anderson to distinguish between Māoritanga and Tohungatanga, saying that the church had nothing to fear from the former and that Christian Māori were trusting Christ to help them work through the latter. This particular article graciously referred to Anderson as "brother". ${ }^{239}$ A protest group appeared in Whangarei opposing the Assemblies of God petition. ${ }^{240}$

Many of the members of the Whangarei congregation did not support the petition and a number of Māori left the fellowship. ${ }^{241}$ The Church subsequently apologised to the local Māori community for the offence caused and Lloyd ultimately left the Assemblies of God ministry. ${ }^{242}$ The Executive's decision not to support the petition seems to have been due to combination of uncertainty within the movement as how best to approach the Māori culture and conviction that a head-on confrontation was not the way to address concerns.

\section{Hira, Chapman and the Significant Conferences}

A number of developments in the 1980s indicated a growing appreciation of the changing social and cultural context in New Zealand, and some willingness to contemplate change. In 1985, Pastor Peter Hira was appointed to the Executive. In his

\footnotetext{
${ }^{237}$ Hoterene Keretene, "Hangi Pits for 'Demon Petition' Organiser," Northern Advocate, 14 May 1976, 2.

${ }^{238}$ Jean Irvine, “The Essence of Māori Religion," Northern Advocate, 15 May 1976, 2.

${ }^{239}$ P. W. Pomare, "Should it be 'Tohungatanga,"” Northern Advocate, 15 May 1976, 8.

${ }^{240}$ Editor, "Pro Māoritanga Group Formed," Northern Advocate, 10 May 1976, 1.

${ }^{241}$ Interview with Graham Cruickshank, 25 February 2009.

242 "Assembly of God Apologises," Northern Advocate, 11 May 1976, 20; Clark, Pentecost at the Ends of the Earth, 189.
} 
opinion this was not a "cultural" appointment. Nevertheless, matters pertaining to Māori culture matters were addressed at his initiative after his appointment. ${ }^{243}$ Although there were a few other pastors of Māori descent within the movement, Hira was to carry much of the responsibility to be its "Māori face".

Few Māori trained in the regional training centres that were so crucial in the expansion of the Assemblies of God in New Zealand. These were based in Auckland, Lower Hutt and Christchurch and injected large numbers of enthusiastic men and women into the movement. ${ }^{244}$ Ordination was not available to women until $1988,{ }^{245}$ but licences to preach were. A number of women sought ordination, including Claire Chapman, who became a significant figure in relation to the church's association with Māori. ${ }^{246}$

Chapman provided the Church with an opportunity to reassess its relationship with Māori, but this was not taken up. She believes this was due to the low priority placed on mission to Māori. In her opinion, the Church appeared to be targeting a higher socio-economic group. ${ }^{247}$ Chapman received her ministerial credentials in $1988,{ }^{248}$ and with her husband Dan, pastored in a number of places, including Waipawa and Taupo. During this time they adopted William, a Māori boy. As a result, the Chapmans became aware of the need for a contemporary version of the Māori Bible. The earlier 1952 version was not understood by some younger Māori. Chapman and her son William set about the task of translation, receiving training through the Wycliffe

\footnotetext{
${ }^{243}$ Peter Hira email to Philip Carew, 21 July 2009; Clark, Pentecost at the Ends of the Earth, 192.

${ }^{244}$ Houston, One Hundred Men, 3, 11.

245 "Assembly of God Conference," The Evangel, December / January 1989, 13.

${ }^{246}$ Interview with Claire Chapman, 2 February 2009; Clark, Pentecost at the Ends of the Earth, 106.

${ }^{247}$ Interview with Claire Chapman, 2 February 2009.

${ }^{248}$ Clark, Pentecost at the Ends of the Earth, 201.
} 
Summer Institute of Linguistics. She was the administrator and provided theological oversight, while William was to do much of the translation.

With limited financial resources available for the project, Chapman appealed for funds from the movement's National Executive. These were not forthcoming. Kem Price, a member of the Executive at that time and the church's Missions Coordinator, commented that he did not think such a translation was necessary as most Māori spoke English. ${ }^{249}$ Despite this, Chapman was given time to speak at the National Conference and, according to Clark, was also given some space in The Evangel. ${ }^{250}$ She insists that she took every opportunity to publicise the project, but could not get the support required. Some leadership were evidently concerned about the Chapman's ability to tackle such a weighty task. ${ }^{251}$ Members of the wider Assemblies of God also worried that the language Chapman was using was not always appropriate and that changes in words used would raise significant theological concerns. ${ }^{252}$ The translation was never completed due to the lack of funding. ${ }^{253}$ Chapman's interest in the project was essentially missiological rather than political, or even covenantal, seeing the Treaty as essentially a political document to be responded to via political processes. ${ }^{254}$

The years between 1988 and 1999 were marked by the greatest consideration of cross-cultural issues, as evidenced by the increased frequency of references to Māori activities in the Assemblies of God publications. Despite this, the sesquicentennial of the Treaty of Waitangi in 1990 passed without comment in The Evangel. This not only

\footnotetext{
${ }^{249}$ Interview with Claire Chapman, 2 February 2009.

${ }^{250}$ A search the 1990s editions of The Evangel failed to find any article on the Māori Bible.

${ }^{251}$ Interview with Ken Harrison, 6 November 2008; interview with Peter Hira 14 May 2009.

${ }^{252}$ Interview with Clair Chapman, 2 February 2009. For example, the word 'tapu,' which Chapman associated with the concept of untouchability, was not to be used in their translation in relation to the Bible or to the Holy Spirit.

${ }^{253}$ Clark, Pentecost at the Ends of the Earth, 214-215.

${ }^{254}$ Interview with Clair Chapman, 2 February 2009.
} 
belied the general change in tone of the period, it contrasted sharply with the Apostolic Church which dedicated the front page of the Apostolic News, and a number of other articles, to the event. ${ }^{255}$ The frequency of references to Māori in The Evangel dropped off significantly at the end of the twentieth century.

Striking evidence of a more responsive tone could be found in Superintendent Jim Williams' claim that an "unhealthy rejection of Māoritanga" was evident in the movement at the church's "National Conference on Māoridom" in 1988. Williams commented that Māori are people of the heart and programmes aimed at them needed to be real, inviting, and straight-talking, yet sensitive. He also believed the movement needed to adopt culturally appropriate methods of training leadership. Hira also spoke at this event. He mentioned that the appropriate use of protocol was good manners and created opportunities to share the gospel. Price commented that churches were always planted and tended within the context of culture, and that European culture should not be forced on Māori. Scriptural truth, however, was not to be compromised. All three men were on the Executive at the time, and each acknowledged the importance of culture awareness in the transmission of the gospel message, with the proviso that syncretism be avoided. $^{256}$

Ambiguity arose at a local Assemblies of God seminar in Hamilton in 1988, entitled "Jesus, Christ to All Peoples". It was stated here that "true cultural identity is not found through cultural pursuits, but only found in pursuit of Christ", and "Christ is above every culture." The report did not elaborate on specific intended implications, or

\footnotetext{
${ }^{255}$ Ron Goulton, "Release Through Recognition, Respect and Righteousness," The Apostolic News, March 1990: 1.

${ }^{256}$ Denis Acraman, "National Conference on Māoridom,” The Evangel, Winter 1988: 10.
} 
how these ideas were to be achieved. ${ }^{257}$ While the meeting was designed as a forum for Māori to express their faith in a cultural context, there appeared to be a downplaying of the place of culture and its intrinsic place in a person's identity. ${ }^{258}$ The event is perhaps indicative of the wrestling that was occurring to understand the place of Christianity within the cultural ferment of the time.

The church's multicultural philosophy was promoted at the Auckland Assemblies, "Cultural Understanding a Key to our Nation" seminar in May 1988. The seminar called for a loving understanding of each other in an increasingly multicultural society. Presentations were made by Samoan, Māori, Tongan and Fijian speakers. ${ }^{259}$ The Evangel reported that the most valuable information was on how to understand and esteem other Christians whose way of life and approach to spiritual questions differed from that valued and practised by New Zealanders of European descent. ${ }^{260}$ While encouraging cultural awareness there was no apparent identification of a bicultural responsibility, yet an apparent pressing need to address the issue persisted.

The Rev. Lionel Stewart, Superintendant of the Māori Ministry Department of the Baptist Church, spoke at the Assemblies of God's "Culture and Evangelism Conference" in 1990 at Ngaruawahia. While the primary objective of the Assemblies of God was and is to "encourage and promote the evangelisation of the world", ${ }^{261}$ the movement clearly recognised a "one size fits all” approach was not going to work. The

\footnotetext{
${ }^{257}$ Ross Smith, "Jesus, Christ to All Peoples,” The Evangel, Winter 1988: 11.

${ }^{258}$ Hana O'Regan, Ko Tahu, Ko Au: Kāi Tahu Tribal Identity (Christchurch: Horomaka Publishing, 2001), 34; M. D. Dominy, "Māori Sovereignty: A Feminist Invention of Tradition," in Cultural Identity and Ethnicity in the Pacific, eds. J. Linnekin \& L. Poyer (Honululu: University of Hawaii Press, 1990), 241; Tauroa, Race Against Time, 18.

${ }^{259}$ Ian Clark, "Cultural Understanding a Key to our Nation," The Evangel, Winter 1988: 18.

${ }^{260}$ Denis Acraman, "National Conference on Māoridom," The Evangel, Winter 1988: 10.

${ }^{261}$ The Assemblies of God, "What We Believe," http://www.agnz.org/about/beliefs/ (accessed June 30, 2009).
} 
conference focused on how to esteem and understand those whose ways are different. Fundamental issues with regard to multiculturalism were raised, with the statement by Stewart that every Christian belongs to a particular culture. Stewart went on to comment that while every believer in Christ assumes a position that is above his culture, conversion does not mean that a person becomes "deculturised". He cautioned that some cultural customs have to be renounced because they are contrary to the Word of God and that culture and values need to be evaluated in the light of Scripture, referring to 1 Corinthians $11: 13{ }^{262}$ Stewart's inference was that Paul's injunction that woman should wear head coverings in church was merely an accommodation of the culture of the day rather than an abiding theological principle. In a sense, Stewart's reasoning actually highlighted the cultural situated-ness of scripture itself. Nevertheless, the effect was to give wider scope for cultural interpretations of the faith.

In 1989, the church was presented with a significant opportunity to explore its connection with Māori when representatives of the Māori Queen attended an ordination at National Conference of a Pastor in New Plymouth who was a relative of the Queen. ${ }^{263}$ As a reciprocal gesture, in 1997 Peter Hira and Superintendent Wayne Hughes were received at Turangawaewae marae by the Māori Queen. ${ }^{264}$ While nothing appears to have come of this, a similar engagement by the Destiny movement was not lost but used to lift that movement's profile significantly. ${ }^{265}$

\footnotetext{
262 "Culture and Evangelism Conference," The Evangel, Autumn 1990: 5.

${ }^{263}$ Interview with Ken Harrison, 6 November 2008.

${ }^{264}$ Interview with Peter Hira, 14 May 2009.

${ }^{265}$ Brian Tamaki, More than Meets the Eye (Auckland: Tamaki Publications, 2006), 340-353.
} 
In 1993, the Evangel reported that Māori only contributed 7\% of the Assemblies numbers. ${ }^{266}$ This was a considerably smaller share than the Apostolic Church which had $23.3 \%$ at the same time. ${ }^{267}$ Annual Conferences in 1996 and 2000 included seminars on methods of outreach to Māori, initiated by Peter Hira. ${ }^{268}$

A few other individuals demonstrated ongoing commitment to the advancement of a Māori perspective within the movement. Prominent among these were Denis and Mina Acraman. Mina (Te Arawa) was appointed to the steering committee for the department of Women's Ministries in $1996 .{ }^{269}$ Both Mina and her co-pastor husband Dennis, who is not Māori, have actively sought to honour the Tangata Whenua by assisting Peter Hira wherever they can in initiatives undertaken to acknowledge Māori within the movement. They identify New Zealand as a multicultural country, but see a need for the establishment of a "Home Mission' to Māori. Both have a strong continuing commitment to seeing justice for Māori in terms of land claims, commenting that "There is no pain neither more finely perceived nor more keenly felt, than the pain of injustice". They were keen to see a position paper on the issue of Justice for Māori being presented at an annual conference. ${ }^{270}$

The 1988 conference was followed up in 1996 with the "National Anniversary Conference on Māoridom" in Picton, which had the potential to clearly define the church's responsibility to Māori. The conference included a tour of a marae with commentary on the history of the area and the significance of the various buildings and carvings. The marae had been "Christianised", involving the dedication of the space to

\footnotetext{
${ }^{266}$ Kevin Ahern, "The Season of Harvest," The Evangel, Autumn 1993: 7.

267 "'Growing, Growing; Let's Keep Going!’The Apostolic News, August 1992: 1.

${ }^{268}$ Clark, Pentecost at the Ends of the Earth, 232; Peter Hira email to Philip Carew, 21 July 2009.

${ }^{269}$ Clark, Pentecost at the Ends of the Earth, 228.

${ }^{270}$ Interview with Denis Acraman, 20 April 2009.
} 
the work of God and the reinterpretation of the aspects of the Pā in light of Christian teaching.

Speakers from the Māori Evangelical Fellowship and Te Hou Ora gave presentations, calling on the Christian community to overturn the damage done to Māori over the years. Māori men reputedly repented of "intergender offences" and Māori women extended forgiveness. There was a call for Pākehā who desired to engage with the culture to get involved in the local marae by "going and peeling a potato". Aspects of the culture, such as haka and waiata, were utilised to communicate elements of the Christian faith. There was great hope at the end of the conference that something would happen as a consequence. However, no specific Māori work developed. ${ }^{271}$ The failure to follow up on these conferences was attributed to the demands of local pastoral responsibilities and the difficulty of getting any sort of national work coordinated due to the emphasis on local church autonomy. ${ }^{272}$

Some churches were successful at accommodating Māori at particular points. Mike Angel (Ngapuhi), pastor of the Picton Assembly in the 1980s, had the church singing songs with verses in English and some in Māori. Scripture texts in Māori were put on the walls of the auditorium. Māori attended the church while he was there, but when he left they also left. Remaining Pākehā took the texts down, seeing no reason to have something on the wall they did not understand, not perceiving a need to make ministry to Māori a priority. Clark observed that Māori often don't feel at home in a

\footnotetext{
271 "National Anniversary Conference on Māoridom," The Evangel, Summer 1999: 16-18.

${ }^{272}$ Interview with Ken Harrison, 6 November 2008; Clark, Pentecost at the Ends of the Earth, 128.
} 
Pākehā church: "They come and go; they don't stay...Perhaps there is something about Pākehā that annoys Māori, but I don't know what it is." 273

In 1999, one notable edition of The Evangel included an explicit call for the church to act justly toward Māori. The article specifically highlighted the importance of covenant in the Bible, referring to the Gibeonite passage from the book of Joshua. ${ }^{274}$ The writer drew attention to the story's indication that in complying not only with the letter but also the spirit of the covenant, the people of Israel were particularly blessed by God. The article concluded with a request that the church search its heart and determine how it can best meet its responsibility to Māori in the light of missionary involvement at the beginning of the colonisation process, suggesting a good place to start was respect for the Māori language. No explicit response to this challenge has been uncovered.

The nature of Māori activism changed, and to some extent diminished in the twenty-first century. The mechanics of dispute resolution and Treaty settlement are well established within the political system, and Government departments have adjusted more to the imperative of acknowledging Māori rights and culture. Some of the larger iwi have moved on to new phases of resource management in the light of settlement with the Crown, while the emergence of the Māori party has altered the perception of Māori needs and opportunities. Consequentially, the pressure to address the question of the place of Māori by a smaller denomination appears to have decreased. Since 2000, very few Māori-related issues have been evident in the pages of the Evangel and Empowered magazines.

\footnotetext{
${ }^{273}$ Interview with Ian Clark, 12 December 2008.

${ }^{274}$ Graham Davidson, “The Treaty: A Christian Response,” The Evangel, Winter 1999: 28.
} 
Yet, there is still a sense of disquiet. In 2007, the Assemblies of God's Annual Conference in Lower Hutt again noted the limited presence of Māori within the movement and appointed Peter Hira to look into the reasons for this. Superintendent Harrison's encouragement was a major factor behind this. He desired to see people within the church get a sense of calling to work with Māori.

\section{Pākehā Pastoral Reflections on Ministry among Māori}

The intensity of spiritual awareness amongst Māori presents particular challenges for the Assemblies of God. Pākehā experience of life is the "invitation" of a spiritual dimension into what is often a very materialistic life style. Māori frequently have a more integrated experience of spiritual and material. ${ }^{275} \mathrm{~A}$ number of pastors were interviewed on their experiences of ministry to Māori.

\section{General Superintendent Ken Harrison}

Harrison grew up with Māori in the Horowhenua and had a number of experiences which underscored the importance of cultural sensitivity for him. As a secondary school exchange student to the United States of America, he sought advice from Kaumātua on how best to represent Māori culture whilst there. Teaching career and present pastoral ministry experiences caused him to question the rejection of Māori culture that he felt characterised the church's traditional approach. Throughout his ministry he established connections with people who could advise him on matters of belief and protocol. Harrison maintains that he is committed to avoiding tokenism, and endeavours to

${ }^{275}$ Royal, ed., The Woven Universe, 24-53. 
honour the culture as best he can. He is enthusiastic about Hira's appointment to review the churches association with Māori.

Nevertheless, cultural engagement has not been without its concerns. Commenting on the high dropout rate among young Māori males in his church, he observed this frequently occurred after they were taken by extended whānau for the purpose of learning their whakapapa. Harrison believes that young Māori are challenged on their commitment to their Christian faith and pressure is brought to bear to return to traditional ways, which are considered incompatible with Christianity. Many of these young people have come from troubled backgrounds and the church had spent considerable time and effort in helping them to get on their feet. Young people, he observed, tended to stay with their faith if whakapapa training occurred prior to accepting the Christian faith. ${ }^{276}$

\section{Pastors Phil and Anthea Fairbrass}

Phil and Anthea Fairbrass pastored in the Wellington / Wairarapa areas for many years. ${ }^{277}$ They spoke of their experiences with Māori in terms of a journey they were walking with members of their congregation. This was a mutual journey of discovery, with no public pronouncement of condemnation, but a shared wrestling with experiences in the context of what appeared to be a committed congregational relationship. There was a willingness to take time in dealing with issues, sometimes amounting to months or years, rather than trying to find the "quick fix solution". Advice was sought from trusted Māori as how best deal with the issues and there was a determined desire to foster Māori leadership within the church.

\footnotetext{
${ }^{276}$ Interview with Ken Harrison, 6 November 2008.

${ }^{277}$ Interview with Phil and Anthea Fairbrass, 27 November 2008.
} 
Their experience differed significantly from those in Whangarei Assemblies of God in a number of areas. The Fairbrasses aimed to pastor in a relational and deliberately non-condemnatory manner, and placed a priority on acting with sensitivity and discretion. They showed a willingness to adopt approaches foreign to their own experience that resonated with Māori, where they could be understood within a Christian frame of reference. For example, they recounted that Māori church members frequently referred to visions and manifestation of spiritual beings. Young Māori were very familiar with what, in Pākehā terms, might be referred to as "paranormal experiences". While demonic deliverance was approached in much the same way as it was for any culture, Māori appeared more aware of its significance. The cleansing of homes after death was a regular occurrence and, although strange to the Fairbrasses, they were able to accommodate this within their theological perspective.

They were surprised at the impact of carving on Māori people and came to believe that there were such things as "sanctified carving" and "non-sanctified carving". They considered that the ability to distinguish between the two was very much in the hands of Māori. The Fairbrasses had no problem meeting on marae, yet encountered a number of Māori who did, saying they felt "spooked" when there. They commented that, "As with any culture, there were expressions of power that were opposed to the power of Christ in Māori culture." 


\section{Pastor Owen Mounsey}

Pastor Owen Mounsey of Lakeside Christian Life Centre, an Assemblies of God fellowship in East Auckland, believes the church has had an underlying "attitude" towards Māori, showing itself in the belief that Māori will not be committed to any particular fellowship. He also perceives an underlying suspicion of the culture. He estimates that his own church is 70 to $80 \%$ Māori. Mounsey is convinced that the church is one people, not two, but believes that injustices to Māori must be put right: "The Christian community must do the right thing. We must honour the Treaty as a covenant agreement." This illustrates ambivalence with the notion of biculturalism, which can be seen as fundamentally divisive, yet an essentially pastoral and evangelistic interpretation of covenant obligation. Mounsey emphasises that there is a need for Māori to be loved and accepted, and to be encouraged to embrace the Kingdom of God in all its fullness and be well supported in their pursuit of Christ. He believes that they must be led by example in word and deed.

Mounsey came from a family with a long, close and positive association with Māori. He believes that the mutual respect derived from this experience has facilitated his work with the Māori community. His reflections were similar to those expressed by Cruickshank, who also emphasised the importance of recognising the Tangata Whenua status of Māori. Both also spoke of the need to respect, love, and appreciate people deeply, implying that acceptance of cultural difference was a necessary ingredient to doing so. ${ }^{278}$

\footnotetext{
${ }^{278}$ Interview with Owen Mounsey, 23 February 2009.
} 


\section{Pastor Peter Tate}

The awareness of a covenantal responsibility in relation to the Treaty of Waitangi was clearly expressed by Peter Tate, who is the pastor of a multicultural congregation in Avondale. He commented:

There are spiritual aspects to any treaty or promise, particularly if the church is involved in the process. Any promise made before God becomes a spiritual matter. To the degree the treaty was a promise between God and men is the degree to which it is of spiritual significance. I think any broken promise should be put right if confidence and trust is to be restored. That is why Treaty claims have been so important and the apology of the Government so necessary. The original involvement of the church of the time is perhaps a little hazier. Nevertheless any efforts by the church to restore trust and relationship with Māori are vitally important and should be followed through energetically. ${ }^{279}$

Tate's comments were part of an interview that focused mainly on the church as a multicultural community, and illustrate a number of critical points. First, he identifies the Assemblies of God with the Christian community involved with the signing of the Treaty, affirming a connectedness to the wider church. Secondly, promises made at the Treaty's signing were important and need to be honoured due, in particular, to their spiritual significance. Thirdly, there is urgency about the need to connect with Māori, to be done, not grudgingly, but enthusiastically.

Tate distances the church from acknowledging any culpability in the events that followed the signing by suggesting it is the responsibility of the government to apologise for past grievances. In response to a question on the needs of Māori within his church Tate referred to the damage caused by the mistreatment in the past:

We need to offer Māori the right to rise up again and become proud of their heritage. We need to somehow help Māori restore their mana. This will only happen as we value Māoridom and all it stands for.

${ }^{279}$ Interview with Peter Tate, 2 April 2009. 
Tate is representative of a newer generation of Assemblies of God pastors. He is active in pastoral ministry in a multicultural church, lectures at the church's Alphacrucis College in Auckland and is currently studying towards an MA in Leadership studies through Alphacrucis College in Australia. In contrast to a previous generation of pastors, he sees social justice as a concern for the church on the grounds that it must deal with the whole person, "socially, physically, materially and spiritually." Tate describes the mono-cultural expression that characterises much of the church's life as not necessarily Christian but European, and perceives a need for the church to accept a wider range of expression in the light of different cultural values. Larger multicultural churches, he believes, need multicultural teams, able to connect effectively with the people of the cultures represented.

\section{Other Pastoral Interviews}

Two pastoral couples interviewed did not believe Māori needed any special consideration. These were pastors who did not hold current pastoral appointments and had worked only part time in pastoral work, mainly with communities that had few Māori. These pastors were also the most reluctant to take up any aspect of Māori cultural expression themselves, with one questioning why the General Superintendant should wear a Māori cloak at the Annual Conference.

There was a general consensus amongst pastors that the church should be a multicultural environment, with Māori cultural needs being addressed as they arose. ${ }^{280}$ Those who had established more successful pastoral relations with Māori had generally

\footnotetext{
${ }^{280}$ Interview with Ken Harrison, 6 November 2008; interview with Neil Hetrick, 23 January 2009; interview with Ian Clark, 12 December 2008; interview with Maurice and Maureen Cowdrey, 1 December 2008; interview with Phil and Anthea Fairbrass, 27 November 2008; interview with Roy Brinck, 16 December 2008.
} 
adopted a number of practices, including greeting Māori in the appropriate manner, attempting to use Māori phrases correctly, and consulting with Māori to find out how they would like their culture to be honoured within the church community. Pastors commented that consultations on the latter question elicited a wide range of responses. They reported that some Māori wanted none of their culture expressed, while others dictatorially sought to impose more of the culture on the congregation than it was able to accommodate. ${ }^{281}$

Some churches sang the National Anthem on a regular basis and ensured that at least one verse was sung in Māori. ${ }^{282}$ A few encouraged the development of Māori cultural groups within the congregation. In the early 2000s, a Māori group was established called "Cloak of Praise" which endeavoured to introduce a "redemptive aspect to the culture" through music at Pakuranga Assemblies of God. ${ }^{283}$ Some churches had cultural nights that provided the opportunity for Māori to perform along with other ethnic groups. $^{284}$

It became apparent from the interviews that those pastors who enjoyed the culture, and more importantly the people, generally reflected this by learning something of the language. They proactively sought to honour Māori by treating their language and culture with respect. They aimed to affirm Māori as Māori by initiating cultural expressions such as the hongi or a greeting in te reo at appropriate times. They would publicly acknowledge the arrival or presence of people within the congregation, and

\footnotetext{
${ }^{281}$ Interview with Phil and Anthea Fairbrass, 27 November 2008.

${ }^{282}$ Interview with Roy Brinck, 16 December 2008; personal observation at the Avalon Assemblies of God.

${ }^{283}$ Interview with Ken Harrison, 6 November 2008.

${ }^{284}$ Interview with Roy Brinck, 16 December 2008.
} 
where the opportunity arose bring them to the front to introduce them to the congregation. $^{285}$

There was a varied response amongst pastors interviewed as to the church's role in considering Māori grievances. All interviewed acknowledged that Māori did have legitimate concerns. Most, however, believed that the responsibility for addressing those concerns belonged with the Government.

The increasingly cosmopolitan make up of the Assemblies of God has seen the acceptance of a wider degree of cultural expression, service formats and governance. Ethnic groups have generally been overseen by the movement's Regional Overseers, with Samoans being the only ethnicity with representation on the Executive Council. Other ethnic groups have appointed spokespeople who liaise with the Executive. Executive members are appointed to keep in touch with specific ethnic groups. The increasing ethnic diversity of the movement has caused the Executive to reflect on the needs of these groups in order to avoid breakaway bodies. ${ }^{286}$

New pastors are informed of the need to be familiar with protocol in all cultural events in which they participate and are encouraged to read a particular Māori protocol book. ${ }^{287}$ Interviews identified particular pastors with Māori in their congregations who attempted, wherever they felt they could, to provide an opportunity for Māori cultural expression.

\footnotetext{
${ }^{285}$ Interviews with members of Avalon Assemblies of God, 27 November 2008; interview with Ken Harrison, 6 November 2008; interview with Neil Hetrick 23 January 2009; interview with Denis and Mina Acraman, 5 June 2009; interview with Owen Mounsey, 23 February 2009; interview with Graham Cruikshank, 25 February 2009.

${ }^{286}$ Clark, Pentecost at the Ends of the Earth, 218, 230.

${ }^{287}$ Interview with Ken Harrison, 6 November 2008. A number of requests for the title of this book did not yield a response.
} 
The interviews were not a statistical sample, or necessarily a representative indication of opinion but are an indication of the range of views held. All European interviewees believed that the Government was on the right track with the settlement process. Māori interviewed also agreed with this. ${ }^{288}$ While recognising that the compensation received was only a fraction of what had been lost, they were satisfied with the acknowledgement that there had been injustices perpetrated and that some tangible recognition of this was required.

As a national movement, the Assemblies of God has interacted with Māori people and Māoritanga in limited ways. At a national level there have been few efforts to consciously reach out into the Māori community. There have been periods of reflection on the comparatively small numbers of Māori within the church's ranks, but no concerted or coordinated responses followed. Some symbolic gestures of cultural recognition have been adopted at occasions like the National Conference. Primarily, however, the impetus for reflection on Māori has been left to individuals or particular congregations. There has been no recognition of "partnership" or of "parallel development" such as these terms are used within bicultural discourse.

There was no recognition in the early years of the movement of any particular responsibility to Māori. If Māori came into the church, they came on the basis of a European cultural and religious perspective. ${ }^{289}$ The intense focus on evangelism that developed in the early 1960s was motivated by the belief in the imminent return of

\footnotetext{
${ }^{288}$ Interviews with staff, parents and supporters of Paparakau Tuarua Kohanga Reo during December 2008.

${ }^{289}$ Interview with Peter Tate, 2 April 2009.
} 
Jesus Christ and there was no time to dedicate to addressing social justice issues. ${ }^{290}$ It is evident from the interviews that the evangelists had a deep concern for people, including Māori, which Māori recognised. ${ }^{291}$ Those evangelistic campaigns amongst Māori did not implement support structures that engaged new converts, maintained their faith, or attempted to assist them in developing a faith expression within their own cultural framework. While this appears to have been successfully achieved in the Samoan experience, it has not been the case with Māori.

While there is now growing support for redress of Māori grievances with respect to the Treaty of Waitangi, these issues are fundamentally viewed as political issues and therefore the responsibility of Government. Similarly, biculturalism is seen as a political category. Notions of covenant are applied at a national political level, or, occasionally in terms of pastoral and evangelistic obligations. There has been little evidence of any deliberation about structural change within the church to reflect bicultural priorities. Indeed, biculturalism is regarded as a potentially divisive ideology. On the other hand, multiculturalism is considered congenial, and consistent with Christianity unity.

As church numbers have increased and the church is playing a more active role in the wider community, the opportunity has arisen for the Assemblies to reflect on whether its understanding of the place of Māoritanga needs to be reconsidered. ${ }^{292}$ Yet, Māori are not present within the Assemblies of God in large numbers. Being a comparatively small religious movement, with relatively few Māori present, and with political grievance and redress processes now well established, militant Māori pressure

\footnotetext{
${ }^{290}$ Pagaialii, Pentecost "to the Uttermost,"138.

${ }^{291}$ Interview with Phil and Anthea Fairbrass, 1 December 2008.

${ }^{292}$ Interview with Ken Harrison, 6 November 2008.
} 
has lessened for organisations like the Assemblies of God to consider bicultural responsibility. So much is evidenced by the reduced number of Evangel and Empowered articles relating to Māori since 2000. It is one of the curious anomalies of the denomination that, while attentive to its commitment to overseas missions, the church has overlooked mission to Māori as a particular area of attention. In the words of Ian Clark,

It's not that the Assemblies of God is anti-Māori, I believe they are just blind to them. They don't see Māori as a mission field; they never have. They have never embraced it. We have a tokenism towards Māori, but that's what it is. ${ }^{293}$

The presence of a larger proportion of Māori within a Pentecostal denomination has the potential to change the church's approach to the culture, but is unlikely to lead to any enthusiasm for biculturalism per se.

${ }^{293}$ Interview with Ian Clark, 12 December 2008. 


\section{CHAPTER FOUR}

\section{Biculturalism, the Apostolic and Destiny Churches}

Thus far, it has been evident that the Assemblies of God has displayed an ambivalent attitude toward Māori. As a whole, the church has made few concerted attempts to accommodate or reach Māori. While increasingly sympathetic to redressing historical Treaty grievances, there was marked resistance to bicultural agendas. Few Māori joined the denomination. By contrast, other Pentecostal churches in New Zealand often were marked by a strong Māori presence. Two, the Apostolic and Destiny churches, have been particularly successful in attracting Māori members. The Apostolic Church formed around the same time as the Assemblies of God in New Zealand, while the Destiny Church was essentially a later offshoot of the Apostolic Church. This chapter assesses the history and characteristics of these two churches in relation to their work among Māori in order to provide a comparison with the Assemblies of God's experience from within the New Zealand Pentecostal tradition.

\section{The Apostolic Church in New Zealand to 1994}

The international origins of the Apostolic Church are found in the Welsh Revival of 1904-1905. It was a Welsh Revival convert, Daniel Powell Williams, who founded the church as a breakaway from the Apostolic Faith Church of the United Kingdom in 
$1916 .^{294}$ While on the surface the break seemed to centre on a range of doctrinal matters, the desire for Welsh autonomy was also a significant concern. ${ }^{295}$

Williams was the leader of the Welsh wing of the Apostolic Faith Church. At one point, he was forced to defend the Welsh pastors from their English counterparts who criticised the poor level of English in their articles in the denominational magazine, Showers of Blessing. ${ }^{296}$ Some time after this, he was replaced as assistant leader in the movement by the leader of the Scottish wing at the instigation of $\mathrm{W}$. O. Hutchinson, the English leader of the church. The aim of this move was apparently to strengthen Scottish-English ties. ${ }^{297}$ Williams experienced deep hurt, and his Welsh ministers rejected the autocratic leadership coming from the headquarters in England. Williams himself is reputed to have said, "I am too staunch a Welshman to permit Pastor Hutchinson to place an Englishman over Wales." 298 The Welsh experience of English control, both in terms of church and state, may have been an important factor in Welsh pastors' sympathy for Māori on their arrival in New Zealand. In any case, the “Apostolic Church in Wales" was formed in 1916. The strong Welsh identity was evident in the new denomination's publication, Riches of Grace, a significant part of which was in Welsh. ${ }^{299}$

\footnotetext{
${ }^{294}$ Worsfold, "Subsequence, Prophecy and Church Order," 3.

${ }^{295}$ Worsfold, "Subsequence, Prophecy and Church Order," 3, 15; James E. Worsfold, The Origins of the Apostolic Church in Great Britain: With a Breviate of its early Missionary Endeavours (Wellington: Julian Literature Trust, 1959) 63. For an alternative interpretation, see Thomas N. Turnbull, What Hath God Wrought: A Short History of the Apostolic Church (Bradford: Puritan Press, 1959), 13, cited in Worsfold, "Subsequence, Prophecy and Church Order," 24.

${ }^{296}$ Worsfold, "Subsequence, Prophecy and Church Order," 13.

${ }^{297}$ Worsfold, "Subsequence, Prophecy and Church Order," 16.

${ }^{298}$ Worsfold, "Subsequence, Prophecy and Church Order," 18.

${ }^{299}$ Worsfold, "Subsequence, Prophecy and Church Order," 21, 24.
} 


\section{Origins of the Apostolic Church in New Zealand}

The Apostolic church came to New Zealand in the early 1930s following an invitation from Pentecostal fellowships in the Wellington region. ${ }^{300}$ Since its earliest days, the Apostolic Church had a strong Māori grouping within it. Outreaches in Blenheim and Waitangi Marae, Te Puke were particularly important in establishing links. These missions were instigated by Apostolic adherents who already had connections with Māori. A miraculous event was said to be the crucial catalyst for the growth of influence among Māori at Waitangi Marae, Te Puke. This occurred when a Māori woman was reputedly raised from the dead. ${ }^{301}$ From this early time, the Apostolic mode of ministry emphasised recognition of cultural structures and values as workers met with Māori on the marae and worked closely with Kaumātua. ${ }^{302}$

The structure of Apostolic leadership was more hierarchical and prophetically oriented than that of the Assemblies of God. Based on 1 Corinthians 12:28, it contained an ordered hierarchy of Apostles, Prophets, Teachers, Workers of Miracles and Healers. The movement was presided over by a President. This appealed to Māori who had their own cultural structures of Ariki, Rangatira and Tohunga. ${ }^{303}$ The hierarchical structure meant that pastoral staff could be appointed to support work wherever the leadership saw fit, and those workers were more amenable to directive oversight. ${ }^{304}$

\footnotetext{
${ }^{300}$ Worsfold, History of the Charismatic Movements, 237.

${ }^{301}$ Hoani Maxwell, “Jubilee Reflections," Apostolic News, July 1984: 3.

${ }^{302}$ Interview with Araiti Remuera, 24 April 2009.

${ }^{303}$ Hoani Maxwell, “Jubilee Reflections,” Apostolic News, July 1984: 3; Ron Goulton, “A Brief History of the Apostolic Church Movement in New Zealand: Part 2," Apostolic News, April/May 2006: 11.

${ }^{304}$ Worsfold, A History of the Charismatic Movements, 258, 259.
} 
By 1939, the movement's work among Māori was sufficiently strong as to warrant the formation of a Māori Home Mission Committee. ${ }^{305}$ Apostolic churches around the country supported the work with Māori through prayer and finance. ${ }^{306}$ Informants often emphasised that Apostolic Māori missioners had a deep love for the Māori people, and sought wherever possible to encourage them to develop their faith within the framework of their culture. ${ }^{307}$ Apostles, such as Pastor Howard Arnold, worked closely with young Māori with the specific intention of developing pastoral leadership for the future. ${ }^{308}$

With this strong emphasis and investment, the movement generated a "critical mass" of Māori. Hui, such as the one at Turangawaewae in 1979 at which Brian Tamaki became a Christian, created a forum where faith could be built up and encouraged in culturally affirming contexts. ${ }^{309}$ Māori leaders established their own evangelistic campaigns and, to a degree, directed their own affairs. There were, however, some tensions. Tamaki commented that he did not want to be associated with the Māori Board. One reason was the politics that he believed dogged the Board. Another was his desire to establish a model of church leadership that was not

\footnotetext{
${ }^{305}$ Hoani Maxwell, “Jubilee Reflections,” Apostolic News, July 1984: 3; Ron Goulton, “A Brief History of the Apostolic Church Movement in New Zealand: Part 2," Apostolic News, April/May 2006: 11; Allen Arnold, "Guest speaker at the Hui, Dr James Forbes Jr.," Apostolic News, July 1984: 1-6; “Apostolic Church Māori Board," Apostolic News, December 1989: 3.

${ }^{306}$ Ron Goulton, "A Brief History of the Apostolic Church Movement in New Zealand: Part 2," Apostolic News, April/May 2006: 11; Ron Goulton, "A Brief History of the Apostolic Church Movement in New Zealand," Apostolic News, October/November, 2006: 2; Hoani Maxwell, "Jubilee Reflections," Apostolic News, July 1984: 3; Interview with Araiti Remuera, 24 April 2009.

${ }^{307}$ Interview with Araiti Remuera, 24 April 2009.

${ }^{308}$ Hoani Maxwell, “Jubilee Reflections,” Apostolic News, June/July 1984: 3.

${ }^{308}$ Interview with Araiti Remuera, 24 April 2009.

${ }^{309}$ Interview with Brian Tamaki, 23 February 2009; Ron Goulton, "A Brief History of the Apostolic Church Movement in New Zealand: Part 2,” Apostolic News, April/May 2006: 11.
} 
determined by race. The politics Tamaki identified centred on a lack of unity within the Māori Board over a number of leadership matters. ${ }^{310}$

\section{The Welsh Pastors}

While many early leaders in the Assemblies of God were English migrants, the Apostolic Church was characterised by a number of Welsh pastors. Cecily Worsfold, wife of former Apostolic President James Worsfold and mother of pastor and historian Luke Worsfold, identified at least five of these, including A. L. Greenway, W. W. Pearson, Willie James, Ivor Grabhan, and T. V. Lewis. It is possible that their Welsh heritage, and shared experience of colonialism and cultural resistance, helped create an affinity with Māori. There was certainly a willingness to support development of distinctively Māori expressions of faith. According to Cecily Worsfold, the church emphasised that members were "all one in Christ", but it was also understood that cultural differences could not be denied. Māori needed to be free to develop their faith within the framework of their own culture. ${ }^{311}$

This assessment was supported by Peter Hira, who became a Christian through the influence of the Apostolic Church, though he later joined the Assemblies of God. He reflected that it was only when he joined the Assemblies of God that he encountered definite negativity toward Māori culture:

But there was the belief in the Assemblies of God that to be involved in anything Māori would mean that you needed to have the Devil cast out of you. It was cultural rape!

\footnotetext{
${ }^{310}$ Interview with Brian Tamaki, 23 February 2009.

${ }^{311}$ Interview with Cecily Worsfold, 18 May 2009. The reference was to Galatians 3:28.
} 
Hira noted that his own father-in-law had been the Welsh Assemblies of God pastor, George Thomas, who had had a very close and successful relationship with Māori. ${ }^{312}$

\section{A Sense of Responsibility}

The significant presence of Māori within the Apostolic Church, and the church's support and sense of responsibility to them, was evident in numerous ways. Until 2002, the denomination's newspaper, the Apostolic News, was published with the subtitle "Te Reo Apotorika”, and, from 1990, a Māori motif that had been designed during the Sesquicentennial of the Treaty of Waitangi.

The Jubilee conference for the New Zealand Apostolic church in 1984 was organised by the Māori Board, and held at the place of the genesis of the church's Māori mission work, Waitangi Marae, Te Puke. The visiting speaker, Professor James Forbes, Jr., an African American professor from Union Theological Seminary in New York, dedicated sections of his addresses to dealing with situations of social injustice, such as he experienced growing up in the United States. He expressed a desire to see people liberated from bondage and free to express awareness through relevant cultural forms. $^{313}$

A review of the Apostolic News between 1981 and 2008 indicates that the Apostolic Church worked steadily to develop relationships with a wide range of political and religious organisations in New Zealand. The President, James Worsfold, was central to this. He effectively coordinated a campaign to ensure that the movement had denominational credibility and respect. While engaging with the largely Pākehā

\footnotetext{
${ }^{312}$ Interview with Peter Hira, 10 June 2009.

${ }^{313}$ Pastor M. Mete, “I Spent Six Days With Dr Forbes,” Apostolic News, July 1984: 4.
} 
“establishment", Worsfold also related closely with Māori. ${ }^{314}$ He expressed strong concern when he saw a drift into what he regarded as negative aspects of Māoritanga in the early 1970's but worked in close association with the Māori Prophet, Pastor J Maxwell. Pastor Ted Davis (Ngāpuhi) trained under Worsfold, ${ }^{315}$ and Māori continued to be appointed to positions of responsibility and high office even after Worsfolds Presidency. Pastor Manuel Renata, a Māori, was made Deputy General Superintendent in $1988,{ }^{316}$ and later became Chairman of the Council, the church's highest leadership body. $^{317}$

\section{Bicultural Policies and Rising Tension}

The relationship between the Māori Board and the National Council became somewhat strained during the 1980s. The events behind this may be interpreted as a test of the extent and legitimacy of the empowerment of Māori leadership. When the Māori Board was established, no clear guidelines or protocols were established. By the early 1980s, some Board members began to express the desire to establish their own. In the same period, the chairman of the Board, David Te Whare, entered into sexual relationship with a married woman. At the same time, there was an increased interest being expressed by some members of the Board in Māoritanga in a manner that caused concern to the National Council. Elements of paganism were perceived as being introduced to the church by Te Whare. Tension between the two bodies deepened, and

\footnotetext{
314 “God Moves in Māori World,” Apostolic News, July 1995: 5.

${ }^{315}$ Ted Davis “Auckland 'full of praise'," Apostolic News, November 1982: 1.

${ }^{316}$ A.V. Arnold, "Anointed for Explosive Expansion," Apostolic News, November 1988: 1.

${ }^{317}$ Worsfold, "Subsequence, Prophecy and Church Order," 238, 253.
} 
eventually the chairman of the Māori Board was stood down. He eventually broke from the movement, taking a small group with him.

Some Māori within the Apostolic movement were apparently unaware of the morality issue due to attempts to keep this confidential. Many Māori therefore perceived the removal of the chairman as an attack on Māori culture. As a consequence, suspicion of Pākehā developed amongst some Māori members. This strengthened the desire for greater autonomy in administering Māori affairs. A newly appointed Māori Board continued these calls, and specifically requested the power to recognise ascension ministries (those of Apostle and Prophet), elect their own chairman, and assert their prime purpose to be one of decision making and direction-giving. They were prepared to then submit their resolutions to the National Council for ratification. ${ }^{318}$ Despite these issues the church maintained its commitment to Māori, and progressively moved toward a consideration of a shared Maori-Tauiwi leadership of the church .

In 1990, the Sesquicentennial of the signing of the Treaty of Waitangi was marked with significant public celebrations and commemorations. These also occurred within the Apostolic Church. In May 1990, the lead article in the Apostolic News was entitled, "Release Through Recognition, Respect and Righteousness". 319 The article was written by the then President of the Church, Ron Goulton, in recognition of the Treaty's signing. The article encouraged the church to "release" Māori to express their faith through their culture, and acknowledged his own growing recognition of the need for cross-cultural acceptance. He felt that people should be seen as "New Zealanders"

\footnotetext{
${ }^{318}$ Worsfold, "Subsequence, Prophecy and Church Order," 25, 253.

${ }^{319}$ Ron Goulton, "Release Through Recognition, Respect and Righteousness," The Apostolic News, March 1990: 1.
} 
rather than European or Māori, but conceded that it was also important to accept varieties of expression. Aspects of all cultures were inconsistent with Christian teaching, but each also contained constructive aspects that enriched the national experience. Goulton supported redress of political injustices toward Māori, but also noted that the church should honour Māori as the Tangata Whenua in ways such as developing Māori expression within their services.

While Goulton's article emphasised the need for "a growing, strong... multiracial church", there was also a clear biculturalism dimension. From March 1990, a Māori language column featured in the Apostolic News with the expressed intent of recognising the Church's responsibility to Māori. This emphasis was maintained. In August 1993, the Apostolic News reported a joint commitment to issues of social justice by the Anglican, Apostolic, Associated Churches of Christ, Baptist, Catholic, Lutheran, Methodist, Presbyterian, Salvation Army and Society of Friends churches. These were related to issues of human dignity, community relationships, the common good, the poor and employment. ${ }^{320}$ This emphasis was underscored nineteen months later when Pastor Manu Pohio made a strong appeal for justice in relation to past violations of the Treaty. Pohio focused on land issues, and called on the church to be active in the search for justice in this regard. ${ }^{321}$ By 1992, the Apostolic Church claimed to have 9,730 adherents. Of these, $23.3 \%$ were Māori, $70.4 \%$ European, and 3\% other Pacific Islanders. $^{322}$

\footnotetext{
320 "The Church, the Crown and Social Justice," Apostolic News, August 1993: 7.

${ }^{321}$ Manu Pohio, "Justice and the Treaty," Apostolic News, May 1995: 6.

${ }^{322}$ Ron Goulton, “Growing, Growing, Let's Keep Going,” Apostolic News, August 1992: 1.
} 


\section{The Rise of the Destiny Movement}

In 1994, Rotorua's Lake City Church, under the leadership of Brian Tamaki (Ngati Ngawaero, Ngati Maniapoto), seceded from the Apostolic Church. Tamaki now has a high profile in the New Zealand media due to his outspoken criticism of the policies of successive Labour-led governments in the 2000s, his church's political aspirations, and his reported lavish lifestyle. In 2003, the Destiny New Zealand political party was formed. This contested the 2005 election, before disbanding in 2007 and re-emerging in alliance with former United Future MPs as the Family Party in 2007. Tamaki's rise to prominence within the Apostolic movement was also dramatic, and by the time of his departure he was leading its second largest church. ${ }^{323}$ The reason for his departure from the Apostolic Church centred on the amount of money churches were required to pay to the National Office, but more significantly over the church's refusal to allow him to set up and lead a separate stream within the movement. ${ }^{324}$

Tamaki is not fluent in te reo, and this factor caused some resistance to his initial appointment to the Rotorua church in 1990. Nevertheless, he is Māori and grew up with rural Māori values, including an appreciation of living off the land and the importance of community and extended family. He values his ancestral links to the Kīngitanga movement and to the last Māori Queen, Te Arikinui Dame Te Atairangikaahu in particular. $^{325}$ Indeed, the Queen memorably asked Tamaki to sit beside her at one of the official events marking the fortieth anniversary of her

\footnotetext{
${ }^{323}$ Brian Tamaki, More than Meets the Eye (Auckland: Tamaki Publications, 2006), 153-154, 251-254.

${ }^{324}$ Rex Meehan, handwritten notes of Council meeting, Waikanae 7 April 1994, and Rex Meehan, informal report of Executive members meeting with Brian Tamaki, Rotorua, 22 March 1994, cited in Worsfold, "Subsequence Prophecy and Church Order," 220; interview with Brian Tamaki, 23 February 2009; Tamaki, More than Meets the Eye, 151-153.

${ }^{325}$ Tamaki, More than Meets the Eye, 34, 122, 348, 340; Wendy Belworthy, "Lake City Celebrates," Apostolic News, January 1992: 4,5.
} 
coronation, and to join her to greet dignitaries. He was also asked to address those gathered at the Ruby Breakfast celebration. ${ }^{326}$ His upbringing and whakapapa, along with the clarity of his teaching, and a willingness to use culture as a vehicle for his message, drew many Māori into the church. ${ }^{327}$

Tamaki is also seen as "successful", and there is clearly an aspirational dimension to his, and Destiny's, popularity among Māori. From early in his association with the Apostolic Church he became renowned for meticulous organisation and planning, especially in terms of record keeping, service format and project management. Tamaki has been able to harness the community ethos and energy of Māori to build a sense of collective identity. ${ }^{328}$ From his present base in Auckland, Tamaki oversees a network of ten churches throughout New Zealand with an additional church in Brisbane, Australia. Services were broadcast on TV One for some time before being withdrawn on the basis of the channel's changed programme structure that could not accommodate the services. Services were then streamed live on the internet. ${ }^{329}$ Destiny had around 7,000 attendees nationwide in 2005-2006, and the church estimates that approximately $75 \%$ of these were of Māori descent. According to Richard Lewis, Tamaki's "right hand man" and the leader of Destiny's political wing, Destiny television has an online viewing audience of between 6,000 and 8,000 for each Sunday service. $^{330}$

\footnotetext{
${ }^{326}$ Tamaki, More than Meets the Eye, 353.

${ }^{327}$ Wendy Belworthy, "Lake City Grows to Fill Cinema," Apostolic News, November 1993: 2.

${ }^{328}$ Michelle List, "Explosive Growth Continues," The Apostolic News, May 1993: 1.

${ }^{329}$ Tamaki, More than Meets the Eye, 191-196. The underlying reason may well have been Tamaki's outspoken comments that had been the cause of numerous complaints to TV One.

${ }^{330}$ Tamaki, More than Meets the Eye, 203; Richard Lewis email to Philip Carew, 12 March 2009.
} 
Viv Grigg notes that there has been a considerable decline in Māori attendance at churches in the Auckland region in recent decades. In 1969, out of an Auckland Māori population of approximately 36,000, only 3\% were attending services of Christian worship. The Anglican Church in Auckland had not been succesful in retaining Māori attendees. Kaumātua reasoned that this was because religious life for Māori is based on the marae and not in Pākehā church structures. Grigg's doctoral research indicated that if Māori were connected with marae they were more likely to attend church if held on the marae. In Grigg's opinion, one striking consequence of Destiny's rapid rise has been the dramatically increased numbers of Māori in church on Sunday in Auckland. ${ }^{331}$

Tamaki insists that he never set out to establish a Māori Church. Indeed, he claims that he endeavoured earnestly to avoid this, preferring a church that reflected New Zealand society as a whole. During his time in the Apostolic movement he attended only one of the Māori Board meetings. Since Destiny commenced, however, Māori have been attracted in large numbers. He believes this is due to his being Māori, and the leadership style he offers. He commented that he can put a middle-class Pākehā pastor in a white suburb and within eighteen months the church will still be $75 \%$ Māori. He now accepts this situation, believing that it is God's will and considers that he has taken on the role of "Te Māngai" to the Māori people. ${ }^{332}$

Tamaki has taken a clear stand in relation to the Treaty of Waitangi, believing it to be a covenant relationship between the Crown and Māori, with God as the third

\footnotetext{
${ }^{331}$ Viv Grigg email to Philip Carew, 15 August 2009. See Viv Grigg, "The Spirit of Christ and the Postmodern City: Transformative Revival among Auckland's Evangelicals and Pentecostals," PhD Thesis, University of Auckland, 2005.

${ }^{332}$ Interview with Brian Tamaki, 23 February 2009. Te Māngai means 'God's mouthpiece', and was the title T. W. Ratana used for himself. See Newman, Ratana the Prophet (Penguin: North Shore, 2009), 39.
} 
party. He believes the Treaty can only function when the signatories are faithful to God. In this interpretation, the Treaty cannot fulfil its role unless the people of New Zealand become faithful to God. This reflects a more general position that sees the keeping of covenants, whether political or marital, as central to social order. When covenants are broken, social upheaval ensues:

Until we as a nation humble ourselves before the One True Living God, the true spirit of Te Tiriti $\mathrm{O}$ Waitangi will not be restored. This process must start with the church and the Crown. ${ }^{333}$

On social justice issues, Tamaki's asserts that, "If the spiritual side of life is put right the rest will follow." This position was also espoused by T. W. Ratana, who led what was arguably the most influential pan-Māori movement in their history in the early decades of the twentieth century. ${ }^{334}$

Destiny addresses social issues through teaching on Christian ethics and morality. The movement acknowledges the existence of historical land grievances, but is not actively engaged in political processes relating to resolving them. ${ }^{335}$ Biculturalism is not specifically endorsed, either in political terms, or in relation to the church's structure and operations. Nevertheless, the large numbers of Māori in leadership and in the movement generally, facilitates distinctively Māori expressions of Christian faith. The church has attracted people who are skilled in leading Kapa Haka and the music, dance and drama of urban Māori youth culture. ${ }^{336}$

\footnotetext{
${ }^{333}$ Tamaki, More than Meets the Eye, 338-339.

${ }^{334}$ Newman, Ratana the Prophet, 199.

${ }^{335}$ Tamaki, More than Meets the Eye, 238-240.

${ }^{336}$ Tamaki, More than Meets the Eye, 333; personal observation at a service of Destiny's Wellington church in 2008.
} 
Tamaki's vision for Destiny is to establish a community that reflects excellence in all areas of life, whether in Kapa Haka, education, health, employment, or worship. This vision has focused on the development of an "open" urban community that would provide members with a comprehensive range of social, educational and spiritual services. At this stage, the church has begun the process by registering as an Urban Māori Authority. The next stage will involve developing a pan-iwi organisation called Iwi Tapu, or "Sacred Iwi". Planning for the development of the physical community is currently underway. Teams from Destiny will be travelling around marae throughout the country with Kapa Haka groups, presenting the idea of Iwi Tapu and outlining the concept of the community, the community's kawa. Iwi Tapu does not seek to set aside other iwi affiliations, but to establish a collective that puts faith allegiance over and above other responsibilities. In this sense, there are some similarities to Ratana's attempts to disestablish iwi due to the hindrance he perceived they were in addressing injustices to Māori. ${ }^{337}$ Destiny does not presently have the size or influence that the Ratana movement finally achieved. ${ }^{338}$ Nevertheless, the concept of Iwi Tapu suggests that it is moving in a similar direction by attempting to provide a comprehensive response to the spiritual, social and political needs of the people. In this context, it is notable that urban Māori leaders like Willie Jackson and John Tamihere have defended Tamaki as a legitimate urban Māori leader. ${ }^{339}$

\footnotetext{
${ }^{337}$ Interview with Brian Tamaki, 23 February 2009.

${ }^{338}$ Newman, Ratana the Prophet, 187.

339 "Destiny's Expansion puts Church in Line for Millions of Government Dollars," Sunday Star Times, http://www.stuff.co.nz/sunday-star-times/features/feature-archive/680007/Destinys-expansion-putschurch-in-line-for-millions-of-government-dollars (accessed April 14, 2009); "Jackson and Tamihere Running for Mayor," New Zealand Herald, http://www.nzherald.co.nz/nz/news/article.cfm?c id=1\&objectid=10459384 (accessed April 14, 2009).
} 


\section{The Apostolic Church from 1994}

While the Apostolic Church had a long history of Māori participation, the departure of Tamaki to form his own movement in 1994 marked a significant turning point. From the mid-1990s, a new era of leadership emerged within the denomination that had significant ramifications for Māori. Change in the Apostolic movement emanated from a conflict of aspirations. In particular, there was a clash between desire for increased autonomy by Māori, and ambition for an increased "market share" by the new Apostolic leadership.

With the departure of Tamaki's Lake City church, Bruce Monk, another rising pastor within the Apostolic movement, and member of the Executive, used the opportunity to promote a new style of leadership. ${ }^{340}$ This was based on clusters of national relational networks rather than the regional organisational structure that had previously existed. ${ }^{341}$ The plan effectively removed the opportunity for Apostles and Prophets to work together with regional groups of pastors. These ministries began to be "deinstitutionalised" and expressed in spontaneous, less formal ways. ${ }^{342}$ Churches formed networks around key pastors whom they had an affinity with. Monk presently leads one of these, the Equippers Network, which has churches in seven New Zealand locations, London, Germany and Tonga. ${ }^{343}$

Interestingly, these new streams were very similar to Tamaki's own idea that had earlier been rejected, and that proved an important factor in his leaving the Apostolic Church to form Destiny. Indeed, Monk and Tamaki were similar in a number

\footnotetext{
${ }^{340}$ Worsfold, "Subsequence, Prophecy and Church Order," 221. Bruce Monk confirmed that this had been his position at the time in a telephone interview, 20 May 2009.

${ }^{341}$ Worsfold, "Subsequence, Prophecy and Church Order," 244.

342 Interview with Bruce Monk, 20 May 2009.

${ }^{343}$ Equippers Church, http://www.equipperschurch.com/ (accessed May 21, 2009).
} 
of ways. Both were strong personalities, and had reputations for decisive action. Both had either dismissed, in Monk's case, or threatened to dismiss, in Tamaki's case, church boards if they did not come into line with their views on tithing of the gross wage to the church. ${ }^{344}$

Monk's decisiveness ultimately led to a number of changes that had significant implications for the Apostolic Church's association with Māori. Monk eventually became the leader of the church, but prior to him taking this position the Maori Board was reorganised into the Māori Pacific Island Council (MPIC) in 1997. This was comprised of any National Council member who wanted to identify with things Polynesian. Its predecessor, the Māori Board, served as a sub-committee of the National Council but, as with MPIC, there was a lack of clear protocols leading to misunderstanding. Some leaders in the MPIC expected equal authority and allocation of comparable funds to the main National Council, but this never eventuated. At the time of the MPIC's creation, the National Council had been considering a proposal for equal representation of Māori and non-Māori members. Although a majority was in favor of such a move, a decision was deferred pending further prayer because the Council was not unanimous on the issue. ${ }^{345}$

In the early 2000s, when Bruce Monk became the "Apostolic Leader", the movement re-branded itself under the name of ACTS, the title gleaned from the New Testament book of Acts. ${ }^{346}$ Around this time, tensions erupted over the refusal of the National Council to recognise the apostleship of Cecily Pohio, wife of MPIC Tumuaki,

\footnotetext{
${ }^{344}$ Worsfold, "Subsequence, Prophecy and Church Order," 157.

${ }^{345}$ Worsfold, "Subsequence, Prophecy and Church Order," 255.

${ }^{346}$ North City Apostolic Church, http://www.northcity.org.nz/whorwe.html (accessed April 15, 2009). The title 'Apostolic Leader' replaced that of 'Superintendent'; the original title had been 'President'.
} 
Manu Pohio. A prophet who had prophesied the appointment of Monk as national leader at a National Council meeting had also prophesied Cecily's apostleship at an MPIC meeting. The MPIC questioned why the National Council could accept the word relating to Monk, but not that regarding Cecily. National Council reasoned that the difference concerned the relative levels of authority afforded the two governing bodies.

In response to this apparent slight, the MPIC publicly ordained Cecily at a hui in August 2002. Monk, believing that the core issue to be one of "leadership and authority, ${ }^{347}$ suspended Pohio from the National Leadership Team and planned input from Pohio and the MPIC to the national conference in October that year was cut. ${ }^{348} \mathrm{~A}$ letter to the National Leadership Team and general council from an unapologetic Pohio explained that his "actions of conviction" resulted from obedience to God, but added that he was sorry his actions had caused offence. ${ }^{349}$ The National Leadership Team met in October, 2002 and, in Pohio's absence, dissolved the MPIC. Monk subsequently invited Pohio to take up membership on the National Leadership Team. He declined on the basis that as the MPIC was dissolved there was no point in having his input. ${ }^{350}$

It is possible that these events were partly shaped by personal friction between Pohio and Monk. ${ }^{351}$ Nevertheless, since the 1980s, and events surrounding the "moral fall" of the former Māori Board Chairman, Apostolic Māori had been increasingly concerned with issues of self-determination and cultural expression. Frustration in this regard, and the perception that they were involved in a long-term struggle for equality

\footnotetext{
${ }^{347}$ Worsfold, "Subsequence, Prophecy and Church Order," 256.

${ }^{348}$ National Leadership Team was the new name for the National Council.

${ }^{349}$ Worsfold, "Subsequence, Prophecy and Church Order," 256.

${ }^{350}$ Interview with Manu Pohio, 22 April 2003.

${ }^{351}$ Worsfold, "Subsequence, Prophecy and Church Order," 257. Pohio was nominated by prophecy to take a place on the Executive in 1989, but Monk was nominated by another Council member, a vote falling in favour of Monk eleven to three.
} 
was also a factor in the "rogue ordination". Pohio saw the ordination as a natural extension of the MPIC's authority, Monk seeing it as a direct challenge to his authority.

Pohio believed that his initiatives as an Apostle were not matching the ideologies of the leadership team and were seen as a threat to the leadership of the movement. In his view, as soon as Māori leadership "came of age" there was increasing difficulty in acceptance of Māori thinking and style of ministry. Māori initiatives were quelled and there was a return to mono-cultural leadership. ${ }^{352}$ While Pohio admitted the MPIC had no mandate to ordain, he felt the action of commissioning Cecily as an Apostle was a logical extension of their sphere. He felt that the current National Leader did not want an MPIC and perceived the National Leadership Team as harbouring a "we know what's good for you" attitude. ${ }^{353}$ It is possible that the notion of the "Māori Mission" has never totally left the movement, militating against establishing equality of government.

Prior to its dissolution, the MPIC had commenced the building of a National Marae for the church in Rotorua. This did not get support from the Apostolic movement as a whole, however, and so was never completed. ${ }^{354}$ Cancellation of the MPIC ultimately left Pohio feeling disempowered, and he ended up leaving the movement.

\section{Recent Developments}

From the period of this conflict, the profile of Māori in the movement has diminished. This has been evident in the reduced number of references to Māori in the Apostolic

\footnotetext{
${ }^{352}$ Interview with Manu Pohio, 14 March 2009.

353 Interview with Manu Pohio, 22 April 2003.

354 “The Māori and Pacific Island Council Vision 2001-2004,” Apostolic News, March 2000: 5.
} 
News. The newspaper was thoroughly revised, presenting a more contemporary magazine layout. As part of an attempt to appeal to a more "up-market" constituency, the paper moved away from a regional input, and there was a higher emphasis on music in worship. Statistics on church growth no longer appeared. The newspaper's Māori title, "Te Reo Apotorika”, previously stated side by side with the English title, appeared less obviously in a vertical format in very small font. The Equippers network appeared to form a significant network of churches within the ACTS Church of New Zealand. The Magazine's last publication was in September 2008 and replaced by The Church Acts / Acts Churches New Zealand in December 2008. ${ }^{355}$

From Monk's perspective, disestablishment of the MPIC was only partly due to the ordination of Cecily Pohio as an Apostle, but reflected wider issues in terms of the position of Māori within the denomination. Monk argues that the Apostolic Church had facilitated Māori people too much. Ultimately, the demand for "partnership" in ministry was inconsistent with the belief there is one church and not parallel streams within one movement. This ideal seems to be particularly based on cultural streaming, given the development of the Equippers ministry stream which has occurred since this time. According to Monk, ministry to Māori will now need to come through the calling of people within congregations, rather than through institutional structures. Some will be better than others at this, and success will depend on the particular leadership of individual congregations. ${ }^{356}$

This approach reflects Monk's view that the Treaty of Waitangi has no place in the teachings of the church, irrespective of the involvement of missionaries in its

\footnotetext{
${ }^{355}$ The Church Acts does have a section devoted to local church activities but the former prominence given to Māori events is absent.

${ }^{356}$ Interview with Bruce Monk, 20 May 2009.
} 
creation, translation, and implementation. He considers that the people of New Zealand as a whole must work out the legislative implications of the Treaty, and the church must abide by the law. Monk does not believe that there has been any attempt to "deMāorify" the church in recent years, but added that it was dangerous to attempt to impose cultural preference into the governance of the church: "The church must be governed according to a biblically based model, and culture cannot dictate to the church how that will be." 357

Though suspicious of "cultural preference", Monk has noted that certain Māori cultural traits could benefit the wider church. In particular, he highlights a greater sense of collective identity, a "What can we do together?" attitude, which contrasts with a more individualistic Pākehā focus on "What will the church do for us?"358 Nevertheless, in Monk's model there was a strong emphasis on creating a unified expression of church culture that denied Māori the opportunity to consolidate their identity through independent structures, or their own stream. Māori who wanted greater freedom of this kind, like Manu Pohio, tended to feel rejected. Pohio felt that Māori needed to exercise constant vigilance to ensure that their aspirations were not overridden. ${ }^{359}$ Some, like Pohio, left the church. By 2009, the proportion of Māori adherents within the Apostolic movement had dropped from 23.3\% in 1992 to around $13.0 \%$ (see Table 3).

\footnotetext{
${ }^{357}$ Interview with Bruce Monk, 20 May 2009.

${ }^{358}$ Interview with Bruce Monk, 20 May 2009.

${ }^{359}$ Interview with Manu Pohio, 15 April 2009.
} 
Table 3: Ethnic Composition of the Apostolic Church, 1992-2009

$\begin{array}{llrrrr} & \begin{array}{l}\mathbf{1 9 9 2}^{360} \\ \text { Ethnic } \\ \text { Composition }\end{array} & \text { Adherents } & \begin{array}{l}\text { A992 } \\ \text { Adhensus } \\ \text { Adhents }\end{array} & \begin{array}{l}\mathbf{2 0 0 6}^{361} \\ \text { Ethnic } \\ \text { Composition }\end{array} & \text { Adherents } \\ \text { Māori } & 23.30 \% & 2,268 & 1,083 & 13.00 \% & \text { Figures } \\ \text { Polynesian } & 3.00 \% & 291 & 750 & 9.00 \% & \text { Not } \\ \text { European } & 70.40 \% & 6,848 & 5,996 & 72.00 \% & \text { Supplied } \\ \text { Other } & 3.30 \% & 323 & 500 & 6.00 \% & \\ \text { Total } & & 9,730 & 8,328 & & \end{array}$

Clearly, in terms of the presence and profile of Māori, the Apostolic Church underwent considerable change during the course of the twentieth century. From the early years of its presence in New Zealand, there had been a significant emphasis on mission to Māori. Though never numerically dominant, Māori were prominent, and they were an important factor in the development of the denomination as a whole. Cultivation of indigenous leadership was an important focus, and by the 1970s there was a reasonably open attitude to the new language of biculturalism that was emerging within society. Biculturalism seemed in harmony with the ethos of the church, and by 1990 the possibility of restructuring church governance along these lines seemed a distinct possibility.

From the 1990s, a number of significant changes occurred. The departure of Brian Tamaki ushered in the system of "Streams", and decentralisation of control to key people. The new leadership had a significantly different understanding of the place

\footnotetext{
${ }^{360}$ Ron Goulton, “Growing, Growing, Let's Keep Going,” Apostolic News, August 1992: 1.

3612006 CensusQSCI, "Religious Affiliation (total responses)," Tables 31.

362 Interview with Bruce Monk, 20 May 2009. The Church was willing to provide a percentage breakdown of ethnic composition from a recent survey, but the total number of adherents was not provided.
} 
of Māori within the church. In response to events that had their genesis prior to 1994, they disestablished the Māori work. Despite the encouragement of relational streams within the present Apostolic / ACTs movement, the potential for ethnic streams is not likely to be countenanced by current leadership. To some extent, the Māori work of the Apostolic Church has migrated to Destiny. The new church has not formally embraced biculturalism because it is largely a Māori movement. The combination of Brian Tamaki's whakapapa, style and charisma has appealed to Māori. He shows an evident concern for the wellbeing of his people and, through his own prosperity, holds out the potential for success to others. While not fluent in te reo, Tamaki had no difficulty using the culture to carry the Christian message, a message that he believes is firmly rooted in the historical experience of Māori. Opportunism rather than planning has resulted in Destiny moving toward a reformist approach to biculturalism. 


\section{CHAPTER FIVE}

\section{The Assemblies of God and Māori in Comparative Perspective}

To date, the story of the Assemblies of God's engagement with Māori has been interspersed with assessments of developments in other churches in New Zealand. This chapter offers an interpretation of the Assemblies of God's experience in relation to Māori during the period since 1970. The aim is to account for the relative weakness of Māori participation within the denomination in the light of the actions and experiences of the other churches. The chapter revisits the question of biculturalism before identifying eight factors that have profoundly shaped the attitudes and actions of the Assemblies of God in this area.

\section{Biculturalism Revisited}

This thesis began noting the confluence of the growth of Pentecostalism and what Michael King called the rise of "Mana Māori". The latter movement was closely associated with Treaty activism and calls for justice. Together, these provided the context in which notions of biculturalism arose within New Zealand. In light of the preceding chapters, it is timely to return to this idea of biculturalism in terms of the churches. What attitude did the Assemblies of God express in relation to biculturalism, and how did that compare with other churches during this time?

While the notion of biculturalism, its forms and meaning, has been contested, certain common features have generally been evident. Biculturalism has generally been related to calls for justice, and has therefore focused on positive outcomes for Māori. Its 
priorities have also been expressed in terms of concern for Māori advancement in Māori terms, with the assumption that Māori do not necessarily wish to live as Pākehā. In Mason Durie's interpretation, biculturalism emphasises access to New Zealand society, rather than marginalisation. It concerns processes that enhance their lives and knowledge, recognising Māori desire to retain a distinct identity based on a unique heritage, common journeys, a familiar environment, and a set of shared aspirations. ${ }^{363}$

Within these broad parameters, emphases differ. For example, two crucial models have been noted. Bicultural reformism has focused on greater opportunities for Māori representation and participation as part of a reshaping of social and institutional life. On the other hand, bicultural distributivism concerns reallocation of resources, or devolution, based on an agreed formula. In more radical forms, distributivism may be highly separatist. Yet, interviews conducted during the course of this research suggest that at least some Māori regard assimilation as inevitable, and in many ways a more realistic outcome than separatism. It is the nature of that assimilation, however, that is to be negotiated: assimilation that may be more aptly described as a "convergence". Māori interviewed tended to advocate more reformist positions that create a more Pacific New Zealand identity, less "European”, while still retaining domains of cultural maintenance such as Kōhanga Reo and Kura Kaupapa schools, and Kapa Haka groups. In the wider society, a greater sense of communal priority, more use of te reo, and an acceptance of kawa and tikanga were desired. ${ }^{364}$

\footnotetext{
${ }^{363}$ Durie, Nga Kahui Pou: Launching Māori Futures, 25.

${ }^{364}$ Interview with Bishop Muru Walters, 2 March 2009; interviews with junior staff at the Paparakau Tuarua Kohanga Reo, 27 November 2008; interview with Simon Hirini and Tuteira Davis, 28 January 2009.
} 
Distributivism and reformism are not the only possible models of biculturalism. They have, however, been the most widely applied, with distributism sometimes viewed as a subset of the "parallel development" model. ${ }^{365}$ Conceptually, "partnership" has been taken as implicit within the Treaty, and has emerged as a fundamental Treaty principle informing bicultural practice. It has become a kind of virtue that runs strongly through the bicultural debate, especially in terms of the relationship between Māori and the Crown. Partnership establishes that the Crown cannot ultimately make decisions over Māori resources, and that processes of shared decision-making are necessary in addressing issues affecting the people of Aotearoa-New Zealand. ${ }^{366}$

In terms of the "mainline churches", the Anglican, Methodist and Presbyterian churches have each adopted models of distributivism. They have resourced separate Māori streams within their movements and provided them with various expressions of self-governance. Partnership has featured significantly in the dialogue surrounding the outworking of these forms. A prevailing image has been that of two streams on common journeys.

The Roman Catholic Church has not adopted a distribitivistic approach. Māori culture is essentially an "add on" to the church's structure. The cultivation of Māori leadership has been problematic, due in part to the requirement for celibacy by priests that has represented an obstacle for Māori ${ }^{367}$ and perhaps restricted the potential of a specifically Māori diocese. As with other mainline churches, however, Catholics have had institutional mechanisms for addressing issues of social justice. Their Commission for Evangelisation, Justice and Development has lobbied government on matters

\footnotetext{
${ }^{365}$ O'Sullivan, Beyond Biculturalism, 16.

${ }^{366}$ O'Sullivan, Beyond Biculturalism, 25.

${ }^{367}$ Interview with Father Gerard Burns, 29 July 2009.
} 
relating to its bicultural obligations, holding it accountable on both Treaty and theological grounds for its responsibilities to Māori.

Despite these accommodations, mainline churches have not been swamped by an influx of actively participating Tangata Whenua. The numbers of Māori census adherents have increased, but at varied rates. Anglican growth has clearly not kept pace with overall Māori population growth, though Catholic adherents have. The proportion of Māori in the Presbyterian and Reformed group has increased at a higher rate than Māori population growth, though they still form a very small grouping within these denominations. Methodist numbers actually dropped slightly. (Refer Table 4 below)

Table 4: 1966 and 2006 Comparative Māori Adherents Statistics

\begin{tabular}{|c|c|c|c|c|c|}
\hline & $\begin{array}{c}\text { Māori } \\
\text { Adherents }\end{array}$ & $\begin{array}{c}\text { Māori } \\
\text { Adherents }\end{array}$ & $\begin{array}{c}\text { Total } \\
\text { Adherents }\end{array}$ & $\begin{array}{c}\text { Māori \% of } \\
\text { Denomination }\end{array}$ & $\begin{array}{c}\text { \% of Total } \\
\text { Māori }\end{array}$ \\
\hline Denomination $^{368}$ & 1966 & 2006 & 2006 & 2006 & $2006^{369}$ \\
\hline Anglican & 60,107 & 72,810 & 554,925 & $13.10 \%$ & $11.06 \%$ \\
\hline \multirow{2}{*}{$\begin{array}{l}\text { Catholic } \\
\text { Presbyterian, } \\
\text { Reformed }\end{array}$} & 36,358 & 69,576 & 507,771 & $13.70 \%$ & $10.57 \%$ \\
\hline & 6,039 & 21,000 & 396,228 & $5.30 \%$ & $3.19 \%$ \\
\hline Methodist & 15,877 & 15,723 & 116,622 & $13.50 \%$ & $2.39 \%$ \\
\hline Apostolic ${ }^{370}$ & 649 & 1,083 & 8,328 & $13.00 \%$ & $0.16 \%$ \\
\hline \multirow{4}{*}{$\begin{array}{l}\text { Destiny } \\
\text { Assemblies of } \\
\text { God }^{372}\end{array}$} & 0 & 5,250 & 7,000 & $75.00 \%$ & $0.80 \%$ \\
\hline & 275 & 1,301 & 15,300 & $8.4 \%$ & $0.20 \%$ \\
\hline & $\begin{array}{c}\text { Total Māori } \\
\text { Population } \\
1966\end{array}$ & $\begin{array}{c}\text { Total Māori } \\
\text { Population } \\
2006\end{array}$ & $\begin{array}{c}\text { Total NZ } \\
\text { Population } \\
2006\end{array}$ & $\begin{array}{c}\text { Māori \% of } \\
\text { Total Population } \\
2006\end{array}$ & $\begin{array}{c}\text { Māori } \\
\text { \% } \Delta \\
1966 \text { - } 2006\end{array}$ \\
\hline & 201,336 & 565,329 & $4,027,947$ & $14.00 \%$ & $180.8 \%$ \\
\hline
\end{tabular}

\footnotetext{
${ }^{368}$ Figures based on 1966 and 2006 Census results unless otherwise stated.

${ }^{369}$ Percentages involved in each denomination do not correlate with total number of Māori as Māori were able to align with more than one denomination in the 2006 census.

${ }^{370}$ Apostolic calculations based on 1966 and 2006 census numbers and 2009 church survey percentage of $13 \%$.

${ }^{371}$ Figures for 2007 provided by Destiny church.

${ }^{372}$ Assemblies of God numbers based on census figures and research survey percentage of $8.3 \%$.
} 
While the loss of influence and credibility among Māori was a factor in the mainline churches' policy, increasing the number of Māori participants was not the primary motivation. Rather, approaches to biculturalism appear to have been motivated from the perspective of redressing historical injustices, partly by the state, but also in terms of the their own policies.

Pentecostals did not embrace this approach. The Apostolic Church came closest to a form of explicit bicultural distributivism around 1990 when it considered the possibility of structural readjustment. Notions of justice and redress did feature during the Worsfold and Goulton Presidency / Superintendancy. In addition, the Apostolic and Destiny movements, as a consequence of close connections with Māori, either developed what may be understood as a "Treaty theology" or worked to deliberately acknowledge the place of Māori in New Zealand society. For the Apostolic Church, this diminished in more recent years. The Treaty has been a particularly strong emphasis within Destiny, but this has not led to overt structural expressions of biculturalism. Such moves seemed unnecessary and irrelevant given the numerical dominance of Māori within the church.

The terms on which the Pentecostal churches like Destiny and the Apostolic Church attempted to respond to Māori were not always clearly defined. In general, cultivating an atmosphere and community environment that help Māori feel at home seemed to be a fundamental consideration. In this sense, numerical growth has been significant, but not necessarily the only concern as indicated by the Apostolics concerns for social justice issues toward Maori in the early 1990s. 
Of the churches considered, the Assemblies of God has been the least receptive to biculturalism in any form. While the church has become increasingly supportive of movements to redress historical injustices, including Treaty claims, these have been viewed almost entirely as issues for the state. The Assemblies did not develop a Treaty theology, nor was there any sustained or coherent engagement with Māori as a distinct community. As Table 4 (above) indicates, there has also been a lower level of involvement both numerically and in proportional terms by Māori in the Assemblies of God.

\section{Factors Shaping the Assemblies of God's Approach to Māori}

Evidently, there has not been a clear correlation between overt acceptance of "bicultural" ideology and a strong Māori presence within denominations. Nevertheless, the Assemblies of God's limited enthusiasm for biculturalism does appear consistent with its limited efforts to engage with Māori generally. This reticence and the persistence of comparatively low levels of Māori participation in the denomination still require explanation. Through analysis of the Assemblies of God itself, and in comparison with the other churches' stories, eight particular factors appear to have been particularly significant.

\section{The Low Priority Placed on Issues of "Social Justice"}

The first factor relates to the justice framework through which so much of the recent discourse about biculturalism and Māori engagement has taken place. Redress of historical Treaty grievances, and reorientation of contemporary society in line with 
principles of "partnership", have often been treated as matters of "social justice". By and large, the Assemblies of God has not been responsive to this language.

The reluctance of more "fundamentalistic" churches to engage in issues of "social justice" dates back to the nineteenth century, and conflicts with liberal Christians who seemed to be more focused on social justice issues. ${ }^{373}$ But the conflict was based more on focus than on the issue of justice per se. ${ }^{374}$ This tension between social justice and conservative theology sharpened in the period in which Pentecostalism emerged, and on through the middle decades of the twentieth century.

As a theologically conservative renewal movement with a fundamentalistic flavour, the Assemblies of God was affected by this suspicion of social activism. From its inception, the denomination emphasised renewal of the church from within, focusing on "gospel preaching" and authentic spiritual experience. Elements of this emphasis have persisted through to the present day. While all the pastors interviewed in the course of the research acknowledged that historical events gave rise to social justice issues for Māori, the majority believed these were the responsibility of the government. For most, the church was not required to be involved in matters of state, or in solving historically grounded social issues. Such matters existed in the world beyond the church. It is evident that the rising profile of the church and the increasing level of education amongst pastors is causing it to consider issues that it has not considered previously.

\footnotetext{
${ }^{373}$ On the "fundamentalistic" terminology, see Brett Knowles, "Is the Future of Western Christianity a Pentecostal One? A Conversation with Harvey Cox," in The Future of Christianity: Historical, Sociological, Political and Theological Perspectives from New Zealand, eds. John Stenhouse and Brett Knowles (Adelaide: ATF Press, 2004), 58.

${ }^{374}$ Justo L. González, The Story of Christianity, Volume 2 (New York: Harper Collins, 1985), 257-258.
} 


\section{A Post-Missionary Era Church}

In New Zealand, there were particular reasons why a church like the Assemblies of God might be less responsive in these matters. In the mainline churches, for example, history was a compelling ingredient in their renewed efforts to connect with Māori and engage with biculturalism in the late twentieth century. These churches had been active in New Zealand's "Missionary Era", a period that can be located within the years of the Anglican Church Missionary Society's operation, from 1814 to $1900 .{ }^{375}$ For much of this period, Māori were culturally and numerically dominant. Establishment of missionary ventures deepened mainline churches understanding of the culture particularly, their involvement with the Māori language. ${ }^{376}$ Concurrent with this was the development of indigenous leadership, a principle already well enunciated in mission literature of the time. ${ }^{377}$ Early contact, then, established a basis for Māori participation. But in terms of later priorities, the churches' involvement in the events at Waitangi in 1840, the inconsistency of their 19th century policy towards Māori, and their loss of influence among them, all affected their willingness to engage with biculturalism in the twentieth century.

By contrast, the Assemblies of God had a reduced opportunity to connect with Māori due to demographic changes, and the fact that Māori had already made commitments to the mainline denominations or Christian Māori forms such as the Ringatu and Ratana churches. By the time of the New Zealand Assemblies formation in 1927, Europeans formed the largest ethnic group in the country with Māori only 5\% of

\footnotetext{
${ }^{375}$ Davidson, Christianity in Aoteoroa, 130.

${ }^{376}$ David W. Carroll, Psychology of Language, $3^{\text {rd }}$ edition, (Monterey: Brooks/Cole, 1999), 364-369; John Edwards, Language Society and Identity (Oxford: Basil Blackwell, 1985), 16-22.

${ }^{377}$ Bill Bennett, God of the Whenua: Rural Ministry in Aotearoa New Zealand (Wellington: Philip Garside Publishing, 2005), 37.
} 
the population. ${ }^{378}$ In the early days, the Assemblies of God largely drew adherents from the European majority community within which it commenced. This pattern continued until the 1960s at least. Furthermore, the late arrival of the Assemblies in New Zealand meant that they played no direct part in the Treaty process. Given the significance of this historical connection for Anglican and Methodists in particular, it seems that a potential source of motivation to engage with later biculturalism was denied.

\section{An Overlooked Mission Focus}

This is not to argue that its rise as a post-missionary era movement can be regarded as a sufficient reason for failing to develop strong Māori participation. This was not an inevitable or insurmountable factor. For example, the Apostolic Church developed slightly later than the Assemblies of God, but engaged with Māori in rural areas soon after its establishment in New Zealand. This occurred because of the missionmindedness of influential adherents. Structures were put in place to support the work, leadership was developed, and a strong Māori community emerged within the denomination. Much later, though in vastly different circumstances, Destiny had no difficulty in attracting large numbers of Māori members. In both cases, strong leadership was necessary, albeit in different forms.

By contrast, the Assemblies of God never engaged with Māori communities in a sustained or deliberate fashion. With the exception of the Waiomio revival and a limited amount of follow up work in Northland, there was no concerted attempt to connect with them. Where outreach did take place, efforts were often localised, and

\footnotetext{
${ }^{378}$ Māori were 64,000; (5\%) of a total population of 1.3 million. See, Encyclopaedia of New Zealand, "Population, Population Trends, and the Census," http://www.teara.govt.nz/1966/P/Population/PopulationFactorsAndTrends/en (accessed July 15, 2009).
} 
tended to occur in a multiculturalist context that ultimately undermined effective connections.

In the early days of the movement, belief in the imminent return of Christ meant that all other issues were regarded as secondary. The desire to obtain as many souls as possible for the Lord before his return did not lend itself to the consideration of wider issues. The idea of attending to a minority of "lost sheep" was displaced by the broad spectrum "whosoever will, may come." 379 In more recent times, competition for "market share" within, but not limited to, the Pentecostal community also tended to restrict the concentration on "high needs" minorities. ${ }^{380}$ Claire Chapman, and Denis and Mina Acraman believe that the Assemblies of God targets a higher socio-economic grouping than that which Māori frequently belong to. ${ }^{381}$ Interestingly, this appears to be the case in the more recent experience of the Apostolic Church which has re-branded, and restructured itself to portray a more contemporary and market-savvy image. This has been achieved, but at the cost of Māori participation. ${ }^{382}$ Decisions made by current leadership with regard to the place of Māori tend to indicate that there can be tension between the desire for church growth and a concern for minority sections of society. Yet the prominence in Jesus' teaching about justice and care for the poor indicates that this may be an overlooked priority. ${ }^{383}$

Leaders with cross-cultural mission experience, such as Graham Cruickshank, tend to be more aware of the necessity of a deliberate missional strategy to increase

\footnotetext{
${ }^{379}$ See Matthew 18:32 and John 3:16; interview with Ian Clark, 12 December 2008.

${ }^{380}$ Clark, Pentecost at the Ends of the Earth, 49-50.

${ }^{381}$ Interview with Claire Chapman, 2 February 2009; interview with Denis and Mina Acraman, 20 April 2009.

${ }^{382}$ Worsfold, "Subsequence, Prophecy and Church Order," 157.

${ }^{383}$ Colin J. D. Greene, Christology in Cultural Perspectives: Marking out the Horizons (Carlisle: Paternoster Press, 2003), 205-207.
} 
levels of Māori participation within the church. Such an approach would involve putting the needs of the receptor group uppermost in their thinking. ${ }^{384}$ Missionary methodology tends to be willing to adapt to the other culture, proactively embracing it, endeavouring to be attuned to what will enable missionaries to effectively engage with the people group, including learning the language. Successful missionaries initiate cultural connection and aspire to establish self-supporting churches with indigenous leadership. $^{385}$

Once again, the Assemblies of God can be contrasted with the Apostolic Church which was organisationally structured to enable workers to stay longer with Māori, facilitating a deeper understanding of the culture. Some of its workers learned the language. ${ }^{386}$ Prayer, as an indicator of focus and priority, was an important part of the Apostolic experience. ${ }^{387}$ Whether as an indication of priority or as the invocation of supernatural assistance, prayer tends to be a precursor to action in Christian circles. In addition to a possible absence of prayer, the Assemblies had no identifiable programme of financial giving to specific work with Māori such as existed among the Apostolics.

For a church that has been active in sending missionaries abroad, the failure to identify Māori as a potential focus for missionary activity remains curious. Nevertheless, Ian Clark's reflection that the Assemblies' have never regarded Māori as a mission field tends to support the contention that they have been overlooked in missionary terms. ${ }^{388}$

\footnotetext{
${ }^{384}$ Phil Parshall, New Paths in Muslim Evangelism: Evangelical Approaches to Contextualisation (Grand Rapids: Baker Book House, 1980), 31-42.

${ }_{385}$ Parshall, New Paths in Muslim Evangelism, 23-27, 81.

${ }^{386}$ Pastor R. L. Arnold had married a Māori and was a competent Māori-speaker. Interview with Cecily Worsfold, 5 September 2009.

${ }^{387}$ Interview with Araiti Remuera, 24 April 2009.

${ }^{388}$ Interview with Ian Clark, 12 December 2008.
} 


\section{An Urban Focus}

Given the lack of missionary emphasis on Māori, another demographic factor proved profoundly important. Historically, levels of Māori participation within the Assemblies of God were affected by the church's urban focus. Analysis of representations at conferences and the location of churches show that the denomination was largely urban during the period prior to 1970. Prior to the period of Māori urbanisation after World War II, this meant that Assemblies of God churches were generally based in areas where few Māori lived in close proximity.

This urban focus continued in the post-war era. Nevertheless, subsequent connection with the newly urbanised Māori communities was limited. A number of factors may have contributed to this. Urbanisation did seem to weaken existing attachments and structures for Māori. This might have provided an opportunity for the Assemblies of God. But the denomination was largely European, and did not have an established culture of engagement with Māori. This made it unlikely to attract disconnected Māori who were often suspicious of Pākehā institutions. ${ }^{389}$ Some commentators have emphasised the idea of a "Culture of Poverty". If this characterised Māori during the period of urbanisation, it was another factor to make Māori wary of engagement with largely European institutions like the Assemblies of God. ${ }^{390}$

The church's lack of proactive connection with Māori resulted in the church tending to analyse the culture from a distance rather than from a desire to engage. The

\footnotetext{
${ }^{389}$ See Pieter de Bres, "Māori Religious Affiliation in a City Suburb," in Conflict and Compromise: Essays on the Māori since Colonization, ed. H. Kawharu (Birkenhead: Reed Books, 2003), 144-166. 390 Anderson, Vision of the Disinherited, 136, 153; Lloyd Martin, One Faith, Two Peoples: Communication Across Cultures in New Zealand (Paraparaumu: Salt Company, 1991), 72-73, citing Oscar Lewis, La Vida: A Puerto Rican Family in the Culture of Poverty (San Juan \& New York: Random, 1968).
} 
research also indicates that an attitude of cultural superiority was conveyed by expatriate leadership in the years prior to 1970, tending to restrict Māori participation.

The urban focus of the denomination exacerbated the difficulty posed by language. Rural Māori spoke mainly Māori until 1941 and only those committed to learning the language could achieve meaningful levels of communication. While it is evident that Bloomfield and Houston learnt some Māori, and Superintendant Jim Williams had a number of prayers he could recite in Māori, use of te reo was very limited.

\section{Urgency and Activism}

Observers of evangelical and Pentecostal Christianity often note that these forms tend to be characterised by a constant sense of urgency, a need to "get busy and do something" that does not always aid relational connections with people. Thus, the leading North American evangelical historian Mark Noll comments:

Evangelicals like the broader American culture they helped shape, value action more than careful thought... The evangelical ethos is activistic, populist, pragmatic, and utilitarian. It allows little space for broader or deeper intellectual effort because it is dominated by the urgencies of the moment. ${ }^{391}$

This observation is possibly even more pertinent to the Pentecostal movement in particular, due to its recent arrival on the religious scene and emphasis on empowerment for action.

\footnotetext{
${ }^{391}$ Mark A. Noll, The Scandal of the Evangelical Mind (Grand Rapids MI: Eerdmans, 1994), 12, cited in Michael Emerson and Christian Smith, Divided by Faith: Evangelical Religion and the Problem of Race in America (New York: Oxford University Press, 2001), 172.
} 
Dimensions of time and relationship are significant ones in the context of Māori culture. John Newton's recent book on James K. Baxter and the Jerusalem community reflects on this dynamic:

To get to know a rural Māori community takes more time than Pākehā are usually willing to spend...time to work, time to kōrero, time to drink endless cups of tea; time to learn how to be still and patient and let experiences come to you on someone else's time. Contrast this with the familiar situation where Pākehā who want something from Māori want it now. ${ }^{392}$

Therefore, for Pentecostal Pākehā New Zealanders, there were significant cultural mentalities to address in order to effectively welcome Māori and accommodate them in community life. This was particularly true in the period prior to Māori urbanisation, but not exclusively.

In 1990, Apostolic Pastor Ted Davis (Ngāpuhi) discussed the kind of attitude necessary for ministering to Māori in rural areas. He referred to the need to have a love of country life and country folk, to refrain from imposing ideas of "time" on the community, and the necessity for transparency of spirit: "The longer it takes the community to see your true heart the longer it will take for them to accept you." He also stressed the importance of having a good name. News travels in rural communities and if you are known to be a practical Christian who identifies with the needs around you, your reputation will be enhanced.

\footnotetext{
392 John Newton, The Double Rainbow: James K. Baxter, Ngāti Hau and the Jerusalem Commune (Wellington: Victoria University Press, 2009), 192-193.
} 
Davis continued with some additional advice on working in a rural Māori community:

1. Do not assume that because you have been welcomed by the elders on the marae that you have arrived. What they have in fact said to you is, "We welcome you; we open up to you; from this point on the relationship will develop or die depending on how you behave towards us. The ball is now in your court." It took nearly four years of being watched and monitored before I was accepted as Tangata Whenua; a trusted local on the Maraes around Kaeo. It was only then that they gave me the funds, resources and authority to minister to the people and to help the youth.

2. Do not assume that they have not heard the gospel. It has been preached ad nausea by every two bob Christian who goes to a tangi. So when you go to a tangi, help with the funeral arrangements, food gathering and preparation, take up an offering from your church. Show the love and compassion of God by the way you minister to the whaunau pani. Love in action is the gospel they heed.

3. Co-operation with the ministers from other denominations. Honour their ordinations. If you are given the privilege of taking the funeral service, share it with other ministers. This is the Māori way.

4. Do you see yourself as a missionary going to save the natives, forget it. This is not your ministry. Likewise, if you see yourself as a father dispensing wisdom to these simple children, stay at home. At the slightest suggestion of superiority or condescension you have lost your intended Māori convert. ${ }^{393}$

One of the most striking aspects of Davis' reflection was the links he drew between the attitudes necessary for ministry to rural Māori and urban conditions of the time. Davis encouraged those involved in working with Māori to examine their own attitudes for condescending or patronising approaches, adding that a fear of gangs needed to be replaced with love, gangs being an integral part of Māoridom today.

Davis' central point was that the relational basis of working with the Tangata Whenua was predicated on the willingness to give time. This was a particularly

${ }^{393}$ Ted Davis, “A Country Practice,” Apostolic News, August 1990: 1. 
profound obstacle for Pākehā Pentecostals. The lack of a history of mission among Māori, particularly in rural settings, was a distinct weakness for the Assemblies of God. In a sense, it made it easier for the absence of Māori to become self-reinforcing.

\section{Organisational Structure}

One of the more specific factors that militated against the establishment of a mission to Māori, and therefore weakened the prospects for Māori participation in the movement, was structural and philosophical. Specifically, the Assemblies of God's emphasis on local church autonomy proved to be a barrier that limited the denomination's capacity for unified and concerted action. Originally rooted in the suspicion of institutions held by the early Pentecostals, and in the independent nature of pastors within the movement, local autonomy made it difficult to get combined church focus on anything except overseas missions. As a consequence even the support of a national administrative office and Bible Schools was always a challenge.

While the drive by committed local leaders has resulted in the successful spread of the movement internationally, it has meant that initiatives are primarily focused on local growth and are unlikely to extend to broader issues of national significance. Initiatives beyond the local church require the attention and commitment of individual activists a perspective reflected in Assemblies of God USA General Secretary J. Roswell Flower's comment that, "If anything is to be done for the colored people, it would seem that someone must get a burden for some type of evangelistic or philanthropic work and devote themselves to it." ${ }^{394}$ It takes considerable energy for

\footnotetext{
${ }^{394}$ Cited in Blumhofer, Restoring the Faith, 247.
} 
initiators to gain success within the Assemblies of God, since success is ultimately comprised of the accumulated support of individual congregations.

In contrast, the Apostolic Church was, historically, more centrally governed. Destiny continues in this tradition. This centralised approach facilitated the allocation of workers and resources to particular projects. Apostolic Pastors were appointed to work at Te Puke, and the national church assisted with the funding of the Māori work. Destiny appoints pastors to new areas, and resources the new work by a combined church giving programme. The same might also be said of the mainline churches. Their structures are somewhat different. Yet, they can also call on centralised resources and strategies to develop more ambitious projects than most individual congregations would attempt. Centralisation provides a pool of ideas, but also the resources to translate these into action.

\section{Leadership Development}

Another factor that has limited the Assemblies of God's capacity to develop high levels of Māori participation has been the limited extent of Māori leadership. This is partly a vicious cycle, whereby the limited number of Māori adherents begets a limited leadership pool. Yet, the potential of Māori to generate strong leaders is well documented, ${ }^{395}$ and the experience of the Apostolic Church in New Zealand suggests that the problem has partly been due to a lack of strategy. For the Apostolic Church, development of indigenous Māori leadership was a clear priority through the middle of the century. Articulate and capable leaders did emerge, including Manuel Renata, Manu

395 King, The Penguin History of New Zealand Illustrated, 123-124, 197, 200-201, 220; William Greenwood, The Upraised Hand: The Spiritual Significance of the Ringatu Faith (Wellington: Polynesian Society, 1942); Newman, Ratana the Prophet, 71-73; J. McLeod Henderson, Ratana: The Man, the Church and the Political Movement (Wellington: A. H. Reed \& A. W. Reed, 1972). 
Pohio and Brian Tamaki. Through a combination of personal charisma, common cultural experience, and the freedom to express themselves in Māori terms, leaders like these were able to attract Māori to the Apostolic movement.

Roland Allen, an Anglican Priest who served in China as a missionary one hundred years ago, saw indigenous ministry as sustainable only when local people, even with minimal theological training, were given leadership of their own people. ${ }^{396}$ Interestingly, insider observers like Graeme Cruickshank saw this process at work within the Assemblies of God itself. Cruickshank, like a number of others, ascribes much of the growth in the denomination after the 1960s to the rise of non-expatriate, New Zealand-born leadership. ${ }^{397}$

The ideal of indigenous leadership has found its way into official Assemblies of God policy. Initially, the Assemblies international missionary strategy was minimal, and focused largely on belief in Spirit-led direction, tuned by trial and error. In time, approaches that had already been enunciated in historic missionary thinking elsewhere were adopted. Thus, the "three self" strategy that Henry Venn had introduced to the Church Missionary Society in 1844 was adopted and propounded by Assemblies of God missiologist Melvin Hodges from the 1950s. ${ }^{398}$ The identification of the need for indigenous leadership training prompted the development of colleges such as Asia Pacific Theological Seminary in the Philippines. ${ }^{399}$ The New Zealand church has benefited from the Assemblies of God USA's work in Samoa, where indigenous

\footnotetext{
${ }^{396}$ Bennett, God of the Whenua, 37.

${ }^{397}$ Interview with Graham Cruickshank, 25 February 2009.

398 "Three self" churches would be self-supporting, self-governing and self-extending developed. See Adrian Hastings, The Oxford History of The Christian Church: The Church in Africa 1450-1950 (New York: Oxford University Press, 1994), 294; Melvin Hodges, The Indigenous Church (Springfield: Gospel Publishing House, 1953), 12, 22.

${ }^{399}$ APTS, http://www.apts.edu/ (accessed July 28, 2009).
} 
leadership quickly fostered the development of a dynamic church. To date, however, no similar focused attention has been on the Māori community with a view to establishing strong and effective Māori leadership.

\section{Multicultural Outlook}

The church's avowed commitment to multiculturalism rather than biculturalism has also proven an impediment to developing a strong ministry among Māori. As early as 1986, the Ministerial Advisory Committee's Puao-Te-Atua-Tu / Day Break report recognised that multiculturalism undermined any prior or particular Māori claims to consideration. The report also drew attention to the practical effects of a multiculturalist policy for Māori. Unless supported by the proactive encouragement of constituent cultures, it effectively becomes a vote for the mono-cultural status quo. ${ }^{400}$ Even if practiced, once a perceived case of injustice or other issues has been addressed, the next pressing issue is picked up and any systemic or structural issue of Māori involvement in New Zealand society is not addressed. ${ }^{401}$

The perceived costs associated with acknowledging Māori through a bicultural priority are a hindrance to its consideration by the church. The potential to alienate constituents of the increasingly ethnically diverse movement make it difficult to justify the appearance of preferential treatment of one culture over another, particularly while that culture is a minority.

Multiculturalism has been expressed through the movement as an acceptance of self-initiating ethnic fellowships, in particular the Samoan stream, and the occasional multicultural events in churches rather than a proactive connection with particular

\footnotetext{
${ }^{400}$ Interview with Peter Tate, 2 April 2009.

${ }^{401}$ PTAT, 19.
} 
cultures. Leadership within the church is aware of the limitations of this expression and the investigation into the relative absence of Māori can be seen as part of a wider consideration of ethnic representation and responsibility within the church.

Attempts between 1988 and 1999 to examine cultural issues and determine how the culture could be approached sensitively, were largely viewed with a multicultural lens with the associated diminution of the Māori imperative. There appears, however, to be little opposition to the concept of a "Māori Stream" within the movement, but as with other ethnic streams, the motivation to create one must come from Māori who are not present in large numbers within the movement.

The Assemblies of God in New Zealand eschewed policies of biculturalism for a variety of reasons, though a preference for notions of multiculturalism clearly provided a crucial rationale. The experience of the mainline churches, and the Apostolic and Destiny churches, however, suggest that formal acceptance of bicultural ideology was not in itself the determining factor in the Assemblies' lack of success among Māori. Indeed, this chapter has argued that rejection of biculturalism was as much a symptom as a cause of disconnection with Māori. A complex range of factors contributed to this situation, though the primary ones were a combination of theological emphasis, historical circumstance, geographical location and the denomination's organisational structure. 


\section{CONCLUSION}

The Assemblies of God have, in common with other Pentecostal groups, placed a significant emphasis on cross-cultural mission. Indeed, this emphasis has been a significant factor in the rapid growth of global Pentecostalism over the past one hundred years. In numerical terms, this approach appears to have been successful. The Assemblies of God's particular strength internationally, suggests there is something effective about its model.

The relatively low numerical presence of Māori within the Assemblies of God in New Zealand is therefore curious. It seems paradoxical that the denomination has been effective in establishing a culturally diverse constituency, yet poor at fostering Māori participation. The central argument of this thesis has been that the perception of limited Māori participation in the denomination is essentially correct. Māori have not joined the Assemblies of God in large numbers. It is not that Māori are entirely absent, or invisible. Indeed, given the relatively high levels of commitment and church attendance noted in Chapter One, the Māori profile in Assemblies of God churches may actually be higher on a week-to-week basis than in the mainline churches. Nevertheless, the overall observation that they are not present in congregations to the same extent as in other Pentecostal denominations, or in proportion to their share of the population, remains correct.

The Assemblies have been conscious of their failure to foster Māori participation. Nevertheless, attempts to scrutinise its processes have been largely been in reaction to wider society attention to the issue, rather than as a part of any philosophical, academic or systematic review. Awareness of failure has not resulted in 
significant changes to attitudes or approaches to biculturalism or to fostering Māori participation in general.

This thesis has identified that the reasons for the absence of Māori are complex, and not able to be reduced to single causes. It is has focused largely on factors that are internal to the Assemblies of God itself, rather than social, cultural, or structural issues beyond the church. ${ }^{402}$ In particular, it has addressed ways that the church has responded to Māori, and its attitudes to biculturalism. Yet, even this narrow focus has highlighted a number of important dimensions. This thesis has demonstrated that the Assemblies of God has never engaged in mission to Māori in a deliberate and sustained fashion. In more recent times, the church has also been suspicious of biculturalism, and the ideals of partnership and "special treatment" that are perceived to go with that.

Chapter Five highlighted eight key factors that have resulted in a comparatively smaller Māori presence within the denomination. These included a range of historical, ideological, and organisational factors. Overall, the combination of a lack of a mission focus on Māori and a multicultural, in preference to bicultural, outlook seem to have been particularly important. For without specific investment of resources into Māori in particular, there has been little capacity to develop a strong Māori presence within the church. The Assemblies' approach to multiculturalism has largely involved accommodation of existing ethnic communities, rather than structural recognition or proportional deployment of resources to them. The example of the Samoan churches illustrates that the ethnic communities that have thrived within the movement have generally been those that emerged from previous deliberate cross-cultural missionary

\footnotetext{
402 Issues of this kind have been addressed to some extent in other studies. See, for example, de Bres, "Māori Religious Affiliation in a City Suburb," 144-166.
} 
activity. Therefore, effective multiculturalism requires cross-cultural mission in the Assemblies of God context. Without it, small ethnic communities remain small.

To engage in mission to, or with, Māori in New Zealand requires some recognition of the special local context, and the place of Māori within it. Recognising this, and shaped by notions of justice and perceptions of obligation to Māori, the Protestant mainline churches in New Zealand implemented policies of bicultural distributivism. Yet this solution has not resulted in large influxes of active participants. Moreover, there is some international evidence that may reinforce the Assemblies of God's caution in adopting that emphasis of ethnic streaming within church communities.

In Divided by Faith, Evangelical Religion and the Problem of Race in America, Michael Emerson and Christian Smith argue that the "post segregation" American church voluntarily drifted into separate communities as a result of "free market" approach to church selection. People chose churches which had economic, political, educational, social and religious perspectives within which they felt comfortable. These were generally differentiated by race. People initially felt affirmed and secure within these homogenous groups. Nevertheless, particular characteristics were reinforced in these segregated communities, which resulted in greater separation. Different cultures developed, reducing the ability of one group to establish close connections with the other. Along with the voluntary segregation came an inequity in the distribution of resources, by virtue of earning power. In practice, African American congregations became more impoverished. White middle class congregations, unaware of the disparities that existed in the wider society, laid the blame for the absence of African 
Americans within their churches at the feet of African Americans who did not feel comfortable there. ${ }^{403}$

Emerson and Smith see this separation as creating the potential for negative interaction as groups define one another by the negative actions of fringe elements. This may more particularly be the case where there are historical grounds for animosity. Developing distinctions between groups decreases their ability to identify with each other. Consequently, issues arising between the groups are dealt with, not on an individual moral or ethical basis, but rather on the more distant political level. Emerson and Smith caution that in the long term a distributivistic model may not be the best solution due to the potential to entrench separation and foster tension. They advocate, in preference, a high degree of social integration amongst communities in order to establish inclusive bonds within them. ${ }^{404}$ They argue that solutions should be not only structural, but also relational. While recognising a place for confession of past grievances and for the forgiving of those grievances, confessions needed to progress to the ability to build close personal friendships with the people of another "color". This involves a decision to overcome personal preference as to the culture individuals choose to associate with in the interests of building a more unified expression of faith. ${ }^{405}$

The implications of Emerson and Smith's research for the New Zealand context are significant, should the Assemblies of God choose to address the issue of Māori participation in its movement directly. The independent nature of local

\footnotetext{
${ }^{403}$ Emerson and Smith, Divided by Faith, 169-172.

${ }^{404}$ Peter M. Blau and Joseph E. Schwartz, Crosscutting Social Circles: Testing a Macrostructural Theory of Intergroup Relations (Orlando: Academic Press, 1984), 12-13, cited in Emerson and Smith, Divided by Faith, 155.

${ }^{405}$ Emerson and Smith, Divided by Faith, 167.
} 
congregations presents a particular challenge. It makes it difficult to establish a unified perspective on the place of Māori in the church's mission, and the desirability of creating a more representative church culture. Emerson and Smith suggest that a reformist approach is actually more costly than a distributivistic one. In the New Zealand context, it would involve reconsideration of the place of Māori in New Zealand society and willingness to consider personal engagement with a culture foreign to the majority of the church's adherents.

Crucially, in conjunction with Emerson and Smith's research this thesis identifies successful reform following a pattern of Concern, Connection, Empowerment and Leadership. It would appear that the local Assemblies of God is currently situated at the level of "Concern": it is "concerned" at the low level of Māori participation. But concern necessitates becoming informed as to the history of Māori and its association with the Christian message and the colonisation experience.

From this, the potential arises for a desire to "Connect" with Māori. According to Emerson and Smith, this connection initially needs to be established through personal friendships. Through relationships of trust, culture is explored and insight is gained into what is important in the culture and why this is the case. Through extended networks of relationships there is the opportunity to establish a "cultural faith community". The creation of a community of this nature will, according to the perspective of Mason Durie, aspire to "Empower" that community. ${ }^{406}$ Historically the Anglican, Apostolic, Methodist, Presbyterian and Catholic churches were all able to achieve this within the structure of their churches and set up specific sections to cater

\footnotetext{
${ }^{406}$ Durie, ed., Nga Kahui Pou, 90-91, cited in O'Sullivan, Beyond Biculturalism, 25.
} 
for this. "Leadership" is necessary for further growth, but it emerges from within this "cultural faith community".

While Emerson and Smith question how advantageous the distributivistic model is, the future is determined by the choices of the parties involved. To this point the bicultural journeys of the Anglican, Apostolic, Methodist, and Presbyterian churches have been similar. Destiny is possibly the only one of the churches considered that has created a structure that is essentially reformist albeit via a different path. Through its Māori leadership, Destiny has been able to retain a unified culture, drawing from both Māori and Tauiwi elements, galvanising the support of a large Māori community in the process. The success of this movement can however be traced back to the early days of the Apostolic Church in New Zealand that considered the need to engage with Māori, connected with them, empowered them and cultivated the required leadership.

The development of a Maori stream within the Assemblies of God will require people with the desire and time to establish connections with Maori people. Their involvement with the culture will need to be proactive, seeking to build relationships of trust and mutual appreciation. At a time when the Māori proportion of the population of New Zealand was considerably smaller than it is today the Apostolic Church identified a need to work with Māori. By a programme of prayer, financial giving and the commitment of personnel it fostered a work amongst the Māori people. Every such work involves challenges that must be worked through, but a commitment to maintaining ongoing relations sustained the work until the decision was made for it to stop. 
This Apostolic approach is not foreign to the Assemblies of God. Overseas mission ventures of this nature have evolved through the nearly one hundred years of the church's existence. Such a home mission strategy, however, may well necessitate a national perspective in order to generate the critical levels of connection required. The question arises as to whether this is achievable, or if the task will be left to the drive of one particularly charismatic individual. 


\section{APPENDIX A:}

\section{Interviews Referred to in the Thesis}

\section{Assemblies of God}

Ken Harrison: Pastor of Harvest Christian Church, Pukekohe, General Superintendant of the Assemblies of God. 6 November 2008.

Phil and Anthea Fairbrass: Pastors, Itinerant Ministry, Wairarapa and Wellington regions. 27 November 2008.

Maurice and Maureen Cowdrey: Retired Pastors, Lower Hutt. 1 December 2008.

Ian Clark: Retired Pastor, Retired Assistant Superintendant and General Secretary of the Assemblies of God in New Zealand, former Principal of Advance Ministry Training Centre and author of Pentecost at the Ends of the Earth. 12 December 2008.

Roy Brinck: Pastor of Hutt City Church, Lower Hutt, Wellington Regional Overseer. 16 December 2008.

Neil Hetrick: Pastor, General Secretary, Assemblies of God in New Zealand. 23 January 2009.

Claire Chapman: Retired Pastor of Rotorua, co-promote of a contemporary Māori version of the Bible. 2 February 2009.

Owen Mounsey: Pastor of Christian Life Centre, East Auckland and former regional coordinator of the Waikato region. 23 February 2009.

Peter Tate: Pastor of Avondale Christian Centre and lecturer at Alphacrucis College, Auckland. 2 April 2009.

Denis and Mina Acraman: Pastors of The Miracle Centre, Hastings. 20 April 2009.

Jim Prime (Ngāti te Tarawa): Retired Northland Region Pastor. 6 May 2009.

Peter Hira: Pastor of Christchurch Worship Centre, former Assistant Superintendant, appointed to review the Assemblies of God's association with Māori. 14 May 2009; 10 June 2009; 21 July 2009.

Nine members of the Avalon Assemblies of God who remain anonymous. 


\section{Apostolic / ACTS Churches New Zealand}

Araiti Remuera: Retired Pastor, Wainuiomata. 20 February 2009; 24 April 2009.

Manu Pohio: Pastor of Charisma Church, Rotorua, former Tumuaki of the Māori and Pacific Island Council and member of the National Leadership Team of Apostolic / ACTS Churches New Zealand. 14 March 2009; 15 April 2009; 22 April 2009.

Cecily Worsfold: Wife of former President of the Apostolic Church, James Worsfold and mother of Church Historian, Luke Worsfold. 18 May 2009.

Bruce Monk: Pastor, National Leader ACTS Churches New Zealand, Director Equippers Network International. 20 May 2009.

\section{Destiny}

Brian Tamaki: Bishop / Leader of Destiny Churches New Zealand. 23 February 2009.

\section{Other Churches and Organisations}

Lloyd Martin: Author of One Faith, Two Peoples. 6 January 2009.

Kevin \& Diane Goldsbury: Former leaders of Te Ora Hou, Former National Director of Youth For Christ, Founders of Living World Mission and Development, Directors of Ignite Sports. 12 January 2009.

Graham Cruickshank: Senior Pastor, Christian Renewal Fellowship, former Assemblies of God missionary to Fiji and Tonga. 25 February 2009; 13 April 2009

Muru Walters: Pihopa o Te Upoko o te Ika (Bishop of the Wellington Māori diocese) and Chairperson of The Social Justice Commission of the Anglican Church. 2 March 2009.

Gerard Burns: Parish Priest of Te Parisi o te Ngakau Tapu, Porirua, Chairperson of the Catholic Justice Peace and Development Commission and Chaplain to the Māori Catholic Community. 16 June 2009.

Jill van de Geer: Minister and President of the Methodist Church of New Zealand. 20 July 2007.

Archdeacon Peter Benge: St James Anglican Church Lower Hutt. 14 September 2009. 


\section{Paparakau Tuarua Kohanga Reo}

Five staff, one former staff member, and two parents were interviewed during December and January $2008 / 09$. They remain anonymous.

Paparakau Tuarua Kohanga Reo supporters Teteira Davis and Simon Hirini were also interviewed:

Teteira Davis (Tuhoe): Ringatu minister, Kapa Haka leader with Whanautahi-Nae Nae College and Tutemaungaroa - a Tuhoe Iwi based Kapa Haka. Davis is also a worker with Te Hua Rangatahi Trust - "nurturing youth" and a rugby coach. 28 January 2009.

Simon Hirini (Te Aitanga a Mahaki): Teacher of Māori at NaeNae College, practitioner of Mau rākau (the taiaha), and of Kapa Haka. 28 January 2009. 


\section{APPENDIX B:}

\section{A Glossary of Māori Words}

Unless otherwise noted, all definitions are derived from: www.Māoridictionary.co.nz

Amorangi: Priest, leader.

Aotearoa : North Island - now used as the Māori name for New Zealand.

Apotorika: The Apostolic Church.

Ariki: Paramount chief, high chief, chieftain, lord, leader, aristocrat, firstborn in a high ranking family.

Hongi: To press noses in greeting.

Hui: Gathering, meeting, assembly, seminar, conference.

Iwi: Extended kinship group, tribe, nation, people, race - often refers to a large group of people descended from a common ancestor.

Kapa Haka: Māori cultural group, Māori performing group.

Kawa: Marae protocol - customs of the marae and wharenui, particularly those related to formal activities such as pōhiri, speeches and mihimihi.

Kawanatanga: Governorship, or the responsibility to oversee and administer, rather than sovereignty. ${ }^{407}$

Kaumātua: Adult, elder, elderly man, elderly woman.

Kawenata: Covenant, testament, charter.

Kīngitanga: The Māori King movement: Established in 1858, in the hope that Māori tribes could deal with the settlers on a more equal political footing. ${ }^{408}$

Kōhanga Reo, Te: Māori language preschool.

Kōrero: To tell, say, speak, talk, address.

\footnotetext{
${ }^{407}$ Ruth Smithies, The Steps Toward Bicultural Action (Wellington: The Catholic Commission for Justice Peace and Development, Aotearoa - New Zealand, 1990), 45.

408 "Kīngitanga - The Māori Monarchy," http://www.monarchy.org.nz/Māori.html (accessed 18 August 2009).
} 
Kura kaupapa: School operating under Māori custom and using Māori as the medium of instruction.

Mana: Prestige, authority, control, power, influence, status, spiritual power, charisma mana is a supernatural force in a person, place or object. Mana goes hand in hand with tapu, one affecting the other.

Mana Motuhake: A Māori political party whose name means separate identity.

Māori: A native or indigenous person of Aotearoa /New Zealand.

Māoritanga: Māori culture, practices and beliefs.

Marae: Courtyard - the open area in front of the wharenui, where formal greetings and discussions take place.

Mau rākau: Arm. Māori martial art, using the taiaha.

Ngā Tamatoa: 'The Young Warriors,' a Māori protest group. ${ }^{409}$

Pā: Fortified village, stockade, inhabitants of a fortified place.

Pākehā: New Zealander of European descent.

Pihopa o Aotearoa: The Anglican Church in Aotearoa, New Zealand and Polynesia

Rangatira: Noble, esteemed, revered. Chief (male or female), chieftain, chieftainess.

Rangi: The heavens or heavenly realm.

Taha Māori, Te: Taha: (side, margin, edge, bank (of a river). i.e. Māori side.

Taiaha: A long weapon of hard wood with one end carved and often decorated with dogs' hair.

Tangata Whenua: Local people, hosts, indigenous people of the land.

Tangi: To cry, mourn, weep, make a sound, weep over. Name given to a Māori funeral.

Tapu Be sacred, prohibited, restricted, set apart, forbidden, under atua protection. Removed from the sphere of the profane and put into the sphere of the sacred. It is untouchable, no longer to be put to common use.

\footnotetext{
${ }^{409}$ Ranganui Walker, Ka Whawhai Tonu Matou: Struggle Without End (Auckland: Penguin, 1990), 210212
} 
Tauiwi: Foreign people, non-Māori, foreigners, immigrants.

Te Aka Puaho: The Presbyterian Māori Synod.

Te Hahi Mihinare: The Church of the Missionary; The Anglican Church.

Te Hahi Weteriana: The Methodist Church.

Te Hinota Māori: The Presbyterian Māori Mission.

Te Hou Ora / Te Ora Hou: A network of faith-based youth and community development organisations working with young people, their whanau and communities in many places across Aotearoa. ${ }^{410}$

Te Reo: The voice, the language.

Te Tiriti o Waitangi: The Treaty of Waitangi is New Zealand's founding document which takes its name from the place in the Bay of Islands where it was first signed, on 6 February 1840.It is an agreement, in Māori and English, that was made between the British Crown and about 540 Māori rangatira (chiefs).

Te Wananga a Rangi: The Presbyterian Ministerial Training programme.

Tikanga: Correct procedure, custom, habit, method, manner, rule, way, code, meaning.

Tino rangatiratanga: Self-determination.

Tohunga: A skilled person, chosen expert, priest - a person chosen by the agent of an atua and the tribe as a leader in a particular field because of signs indicating talent for a particular vocation.

Tohungatanga: Expertise, competence.

Tūhoe: Tribal group of the Bay of Plenty.

Tumuaki: Head (leader), president, principal, head of an institution, chancellor.

Tūrangawaewae: Main marae of the Kīngitanga at Ngāruawāhia.

Waiata: Song, chant, psalm.

Wānanga: A seminar, conference, forum, a tertiary institution that caters for Māori learning needs. Tribal knowledge, lore, learning.

${ }^{410}$ Te Ora Hou http://www.toh.org.nz/ (accessed 16 July 2009). 
Whakapapa: Genealogy, genealogical table, lineage, descent.

Whānau: Extended family, family group, a familiar term of address to a number of people.

Whānau pani: Chief mourners, bereaved family - the relations of the deceased. 


\section{BIBLIOGRAPHY}

\section{Newspapers and Magazines}

Apostolic News-Te Reo Apotorika (1981-2008).

Dominion Post (selected).

Empowered: Magazine of the Spirit Empowered Life (2005-2008).

New Zealand Evangel Magazine (1968-2004).

New Zealand Herald (selected).

Northern Advocate (selected).

NZ Listener (selected).

Sunday Star Times (selected).

Sunday Times (selected).

Wanganui Chronicle (selected).

\section{Books and Articles}

Anderson, Robert Mapes. Vision of the Disinherited: The Making of American Pentecostalism. New York: Oxford University Press, 1979.

Anderson, Allan. A Dictionary of Mission Theology, ed. John Corrie, 281-285. Nottingham: IVP, 2007. . An Introduction to Pentecostalism.Cambridge: Cambridge University Press, 2004.

. "The Forgotten Dimension: Education for Pentecostal-Charismatic Spirituality in Global Perspective."

http://artsweb.bham.ac.uk/aanderson/Publications/forgotten dimension.htm (accessed August 14, 2009).

. "The Origins of Pentecostalism and its Global Spread in the Early Twentieth Century."

http://www.ocms.ac.uk/docs/Allan\%20Anderson\%20lecture20041005.pdf (accessed August 14, 2009). 
Ashton, Lloyd. "The making of a radical bishop." Mana Online, 'http://www.manaonline.co.nz/bishop_vercoe/vercoe2.htm (accessed June 2, 2009).

Ballantyne, Tony. "Christianity, Colonialism and Cross-cultural Communication." In Christianity, Modernity and Culture, ed. John Stenhouse, 23-57. Hindmarsh: ATF Press, 2005.

Barber, Ian. "Between Biculturalism and Assimilation: The Changing Place of Māori Culture in the Twentieth-Century New Zealand Mormon Church." New Zealand Journal of History 29:2 (October 1995): 142-69.

Beale, Fleur. Sins of the Father: The Long Shadow of a Religious Cult, A New Zealand Story. Dunedin: Longacre, 2009.

Belich, James. Making Peoples: A History of the New Zealanders From Polynesian Settlement to the End of the Nineteenth Century. Auckland: Penguin, 1996.

Bennett, Bill. God of the Whenua: Rural Ministry in Aotearoa New Zealand. Wellington: Philip Garside Publishing, 2005.

Bi-cultural Commission of the Anglican Church, 1986. Te Ripoata a te Komihana mo te Kaupapa Tikanga Rua mo te Tiriti o Waitangi. The Report of the Bi-cultural Commission of the Anglican Church on the Treaty of Waitangi. Auckland: Church of the Province of New Zealand, 1986.

Bishop, Russell. Culture Speaks. Wellington: Huia Publications, 2006.

Blumhofer, Edith L. Restoring the Faith: The Assemblies of God, Pentecostalism, and American Culture. Urbana: University of Illinois Press, 1993.

Booth, Ken N. "Church and Nation: A Pākehā Perspective on Tino Rangatiratanga." In The Selwyn Lectures: Church and State: Te Tino Rangatiratanga: 1996, ed. Janet Crawford, 1-36. Auckland: The College of St John the Evangelist, 1998.

Burgess, Stanley M. and Eduard M. Van Der Mass, eds. The International Dictionary of Pentecostal Charismatic Movements. Grand Rapids: Zondervan, 2002.

Caroll, David W. Psychology of Language. $3^{\text {rd }}$ edition. Pacific Grove: Brooks / Cole Publishing, 1999.

Clark, Ian G. Pentecost at the Ends of the Earth: The History of the Assemblies of God in New Zealand, 1927-2003. Blenheim: Christian Road Ministries, 2007. 
Clark, Margaret, ed. Three Labour Leaders: Nordmeyer, Kirk, Rowling. Palmerston North: Dunmore Press, 2001.

Copan, Paul. Passionate Conviction. Nashville: B\&H Publishing Group, 2007.

Conn, Joann Wolski, ed. Women's Spirituality: Resources for Christian Development. Mahwah: Paulist, 1986.

Cruickshank, Graham. Io Origins. Whangarei: Graham Cruickshank, 1998.

Davidson, Allan K. Christianity in Aotearoa. $3^{\text {rd }}$ edition. Wellington: Education for Ministry, 2004.

Dayton, Donald W. The Theological Roots of Pentecostalism. Grand Rapids: Zondervan, 1987.

de Bres, Pieter H. "Māori Religious Affiliation in a City Suburb." In Conflict and Compromise: Essays on Māori since Colonisation, ed. I.H. Kawharu, 144-166. Wellington: A.H. \& A.W. Reed, 1975

Dow, Derek A. "Pruned of its Dangers." The Tohunga Suppression Act 1907." Health and History 3:1 (2001): 41-64.

Dowley, Tim, ed. A Lion Handbook the History of Christianity. Oxford: Lion, 1990.

Durie, Mason. "Contemporary Māori Development: Issues and Broad Directions." In Nga Kahui Pou: Launching Mãori Futures, ed. Mason Durie, 87-103. Wellington: Huia Publishers, 2003.

Durie, Mason. Mauri Ora: The Dynamics of Māori Health. Auckland: Oxford University Press, 2001.

Edwards, John. Language Society and Identity. Oxford: Basil Blackwell Ltd, 1985.

Emerson, Michael and Christian Smith. Divided by Faith: Evangelical Religion and the Problem of Race in America. New York: Oxford University Press, 2001.

Gilling, Bryan. "We Have Put our Hand to the Plough.” Stimulus 7, no. 2 (May 1999): 3-10.

González, Justo L. The Story of Christianity: Volume 2. New York: Harper Collins, 1985.

Greene, Colin J. D. Christology in Cultural Perspectives: Marking out the Horizons. Carlisle: Paternoster Press, 2003. 
Greenwood, William. The Upraised Hand: The Spiritual Significance of the Ringatu Faith. Wellington: Polynesian Society, 1942.

Harper, Jonathan. "The Church that's Taking Over Auckland.” Metro, no 29 (1983): 122-135.

Hastings, Adrian. The Oxford History of the Christian Church: The Church in Africa 1450-1950. New York: Oxford University Press, 1994.

Hayward, Janine. "The Principles of the Treaty of Waitangi." http://www.waitangitribunal.govt.nz/doclibrary/public/Appendix(99).pdf (accessed July 21, 2009).

Henderson, J. McLeod. Ratana, The Man, the Church and the Political Movement. Wellington: A. H. Reed \& A. W. Reed, 1972.

Hocken, Peter. Streams of Renewal: The Origins and Early Development of the Charismatic Movement in Great Britain. Exeter: Paternoster Press, 1986.

Hodges, Melvin. The Indigenous Church. Springfield: Gospel Publishing House, 1953.

Houston, Hazel. Being Frank: The Frank Houston Story. London: Marshall Pickering, 1989.

Houston, Hazel. One Hundred Men. Wellington: Hazel Houston, 1977.

Isaac, T. and B. Haami. True Red: The Life of an ex-Mongrel Mob Gang Leader. Pukekohe: True Red, 2007.

Jamieson, Alan. A Churchless Faith: Faith Journeys Beyond Evangelical, Pentecostal \& Charismatic Churches. Wellington: Philip Garside Publishing, 2000.

Johnstone, P. and J. Mandryk. Operation World: $21^{\text {st }}$ Century Edition. Carlisle: Paternoster Press, 2001.

King, Michael. The Penguin History of New Zealand Illustrated. North Shore: Penguin, 2007.

Knowles, Brett. "Is the Future of Western Christianity a Pentecostal One? A Conversation with Harvey Cox," In The Future of Christianity: Historical, Sociological, Political and Theological Perspectives from New Zealand, eds. John Stenhouse and Brett Knowles. Adelaide: ATF Press, 2004.

Knowles, Brett. New Life: A Brief History of the New Life Churches in New Zealand, 1942-1979. Dunedin: Third Millennium, 1999. 
Levin, Tanya. People in Glass Houses: An Insider's Story of Life in and Out of Hillsong. Melbourne: Black Inc. 2007.

Maddox, Marion. God Under Howard: The Rise of the Religious Right in Australian Politics. Crows Nest: Allen \& Unwin, 2005.

Martin, Lloyd. One Faith, Two Peoples: Communication Across Cultures in New Zealand. Paraparaumu: Salt Company, 1991.

Metge, Joan. Talking Past Each Other. Wellington: Victoria University Press, 1984.

Ministerial Advisory Committee on a Maori Perspective for the Department of Social Welfare. Puao-te-Ata-tu [PTAT]/ Daybreak. Wellington: Department of Social Welfare, 1986.

Ministry of Social Development. The Social Report: Te Pūrongo Oranga Tangata, 2008. Wellington: Ministry of Social Development, 2008.

Naumann, Ruth, Lyn Harrison and Te Kaponga Winiata. Te Mana o Te Tiriti. Auckland: New House Publishers Ltd, 2004.

Newman, Keith. Ratana the Prophet. North Shore: Penguin, 2009.

Newton, John. The Double Rainbow: James K. Baxter, Ngāti Hau and the Jerusalem Commune. Wellington: Victoria University Press, 2009.

New Zealand History Online. "The Christian Missionaries Agents of Virtue," http://www.nzhistory.net.nz/culture/the-missionaries (accessed 24 September 2008).

Nicholson, Rangi. Te Tiriti o Waitangi: Monitoring Māori Language and Cultural Policies of the Anglican Church in Aotearoa, New Zealand and Polynesia http://www.groupsthatclick.com/files/aams/Nicholson.pdf (accessed April 15, 2009).

Orange, Claudia. The Treaty of Waitangi. Wellington: Allen \& Unwin, 1987.

Orbell, Margaret. The Illustrated Encyclopedia of Māori Myth and Legend. Christchurch: Canterbury University Press, 1995.

O'Sullivan, Dominic. Faith, Politics and Reconciliation: Catholicism and the Politics of Integrity. Wellington: Huia, 2005.

Pagaialii, Tavita. Pentecost to the Uttermost: A History of the Assemblies of God in Samoa. Baguio: APTS Press, 2006. 
Parshall, Phil. New Paths in Muslim Evangelism: Evangelical Approaches to Contextualisation. Grand Rapids: Baker Book House, 1980.

Phillips, Jock. "Māori People of New Zealand." In Te Ara: The Encyclopaedia of New Zealand. Auckland: David Bateman, 2006.

Phillips, Timothy R. and Dennis L. Okholm. A Family of Faith. Grand Rapids: Baker Academic, 2001.

Piper, Edward. "Faith Development: A Critique of Fowler's Model and a Proposed Alternative." http://www.meadville.edu/journal/2002_piper_3_1.pdf (accessed online 30 December 2008).

Reed, A. W. Māori Myth and Legend. Wellington: A. H. \& A. W. Reed Ltd, 1983.

Robb, Loren, ed. Kawa Marae: A Detailed Guide to Marae Visits. Wellington: Communications Department of the Presbyterian Church of New Zealand, 1992.

. Mahi Tahi: Resources for Bicultural Partnership. Wellington: Communications Department of the Presbyterian Church of New Zealand, 1992.

Te Hinota Māori: The Māori Synod and Māori Spirituality and Ministry. Wellington: Presbyterian Church of Aotearoa New Zealand, 1992.

. Te Kakano o te Aroha: The Church Marae of the Wellington Māori Pastorate. Wellington: Communications Department of the Presbyterian Church of New Zealand, 1992.

. Te Maungarongo The Ancestral House of the Māori Synod. Wellington: Communications Department of the Presbyterian Church of New Zealand, 1992.

Robeck, Cecil M. The Azusa Street Mission and Revival. Nashville: Nelson Reference and Electronic, 2006.

Roberts, John. Towards a Bi-Cultural Church: Te Haahi Weteriana o Aorearoa: A Resource Book. Auckland: Joint Working Committee on Bi-Culturalism, 1988.

Rogers, Darrin J. "The Assemblies of God and the Long Road to Racial Reconciliation.” Assemblies of God [U.S.A.] Heritage vol. 28 (2008): 50-61.

Royal, Charles, ed. The Woven Universe: Selected Writings of Rev Māori Marsden. Otaki: Estate of the Rev Māori Marsden, 2003.

Sawyer, John F. A. The Bible and Culture. Malden: Blackwell Publishing, 2006. 
Scott, Dick. Ask That Mountain: The Parihaka Story. North Shore: Penguin, 1975.

Scott, Stuart. The Travesty of Waitangi: Towards Anarchy. Dunedin: Campbell Press, 1995.

Sharp , Andrew. Justice and the Māori: The Philosophy and Practice of Māori Claims in New Zealand Since the 1970's. $2^{\text {nd }}$ edition, Auckland: Oxford University Press, 1997.

Smith, Linda Tuhiwai. Decolonising Methodologies - Research and Indigenous Peoples. Dunedin: Otago University Press, 1999.

Smithies, Ruth. The Steps Toward Bicultural Action. Wellington: The Catholic Commission for Justice Peace and Development, Aotearoa - New Zealand, 1990.

Tamaki, Brian. More than Meets the Eye. Auckland: Tamaki Publications, 2006.

Tauroa, Hiwi, Human Rights Commission. Race Against Time. Wellington: Race Relations Conciliator, 1982.

Te Whāiti, Pania, Mārie Mc Carthy and Arohia Durie. Mai I Rangiātea: Māori Wellbeing and Development. Auckland: Auckland University Press, 1997.

Vercoe, Whakahuihui. “A Self-sufficient Māoridom.” In Vision Aotearoa: Kaupapa New Zealand, eds. Roslie Capper and Amy Brown. Wellington: Bridget Williams Books, 1994.

Walker, Ranganui. Ka Whawhai Tonu Matou: Struggle Without End. Auckland: Penguin, 1990,

Watt, David Harrington. A Transforming Faith: Explorations of Twentieth-Century American Evangelism. New Brunswick: Rutgers University Press, 1991.

Webster, Peter. Rua and the Māori Millennium. Wellington: Victoria University Press, 1979.

Williams P. J. The New Testament in its First Century Setting. Grand Rapids: Eerdmans, 2004.

Worsfold, James E. A History of the Charismatic Movements in New Zealand. Bradford: Julian Literature Trust, 1974. . The Origins of the Apostolic Church in Great Britain: With a Breviate of its Early Missionary Endeavours. Wellington: Julian Literature Trust, 1959. 


\section{Theses}

Beatson, Elizabeth. "The Bi-Cultural Commission of the Anglican Church on the Treaty of Waitangi, 1984-86.” MA Research Exercise, Massey University, Palmerston North, 2000.

Grigg, Viv. "The Spirit of Christ and the Postmodern City: Transformative Revival Among Auckland's Evangelicals and Pentecostals." PhD Thesis, University of Auckland, Auckland, 2005.

Hjalmeby, Erik J. "A Rhetorical History of Race Relations in the Early Pentecostal Movement, 1906-1916.” MA Thesis, Baylor University, Waco, 2007.

Irwin, James. "The Rise and Fall of a Vision: Māori in the Midst of Pakeha in the Presbyterian Church of New Zealand." PhD Thesis, Victoria University of Wellington, 1994.

Moetara, Simon. "An Exploration of Notions of Māori Leadership and a Consideration of their Contribution for Christian Leadership in the Church of Aotearoa-New Zealand Today." MA Thesis, Laidlaw College, Auckland, 2008.

Worsfold, Wesley Luke. "Subsequence, Prophecy and Church Order in the Apostolic Church, New Zealand.” PhD Thesis, Victoria University of Wellington, 2004.

\section{Websites}

Asia Pacific Theological College. "About APTS: Historical Background." http://www.apts.edu/ (accessed 28 July 2009).

Assemblies of God, N.Z. "Find a Church." http://www.agnz.org/about/findachurch/ (accessed 17 June 2009).

"What We Believe." http://www.agnz.org/about/beliefs/ (accessed June 30, 2009).

Assemblies of God USA. "Statistical Report 2006." http://ag.org/top/About/statistics/Statistical_Report_2006.pdf (accessed 5 May 2009).

"Assemblies of God World Missions Report for 2007." http://worldmissions.ag.org/downloads/PDF/agwm current facts 08.pdf (accessed 5 May 2009). 
Assemblies of God World Missions. http://worldmissions.ag.org/regions/ (accessed 15 July 2009).

Buick, T. L." The Treaty of Waitangi: Hobson's Brief from the Colonial Office." http://www.treatyofwaitangi.net.nz/LordNormanbysBrief.html (accessed 5 June 2009).

Catholic Church of New Zealand. "Building Community: Many Traditions, One Faith." http://catholic.org.nz/themes/theme_building.php (accessed 22 July 2009).

Christian Witness Ministries. http://www.christian-witness.org/ (accessed 27 May 2009).

Department of Labour. "Annual in Depth Report - Wellington Region." http://www.dol.govt.nz/PDFs/aidr-wellington.pdf (accessed 19 June 2009).

Department of Labour Wellington Regional Report. "Wellington and New Zealand Figures." http://www.dol.govt.nz/PDFs/aidr-wellington.pdf (accessed 9 April 2009).

Department of Statistics. "Wellington Region Community Profile." http://www2.stats.govt.nz/domino/external/web/commprofiles.nsf/findinfobyar ea/09-rc (accessed 19 March 2009).

Equippers Church. "Equippers Church.” http://www.equipperschurch.com/ (accessed 21 May 2009).

Māori Health. "Demographic, Population Projections." http://www.Māorihealth.govt.nz/moh.nsf/indexma/population-projections (accessed 19 August 2009).

New Zealand History Online. "Māori Text - Read the Treaty." http://www.nzhistory.net.nz/politics/read-the-treaty/Māori-text (accessed 3 June 2008).

North City Apostolic Church. http://www.northcity.org.nz/whorwe.html (accessed 15 April 2009).

Presbyterian Church of New Zealand. http://www.presbyterian.org.nz/ (accessed 21 July 2009).

Smith Wigglesworth.com. "David du Plessis 1905-1987," http://www.smithwigglesworth.com/pensketches/duplessis.htm (accessed 6 June 2009). 
Te Ara: The Encyclopaedia of New Zealand. http://www.teara.govt.nz/ (accessed 21 April 2009).

World Facts Book. "Samoa (WS)." http://www.enotes.com/world-fact-book/samoa-ws (accessed 30 June 2009). 